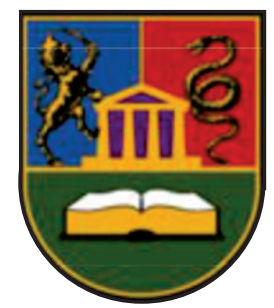

УНИВЕРЗИТЕТ У КРАГУЈЕВЦУ

ФАКУЛТЕТ МЕДИЦИНСКИХ НАУКА

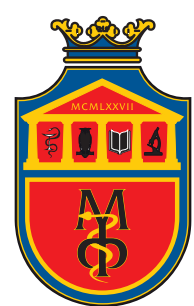

ДИЈАГНОСТИЧКИ ЗНАЧАЈ ОДРЕЪИВАЊА НИВОА ЛИПОКАЛИНА УДРУЖЕНОГ СА НЕУТРОФИЛНОМ ГЕЛАТИНАЗОМ У УРИНУ КОД БОЛЕСНИКА СА ЛУПУС НЕФРИТИСОМ

докторска дисертација

Прим др Виолета Рабреновић

Ментор проф. др Зоран Ковачевић

Крагујевац, 2013 


\section{ЗАХВАЛНИЦА}

Овом ирриликом се најискреније захваљујем свом менйору йроф. gр Зорану Ковачевићу на йоgршии, несебичној йо-

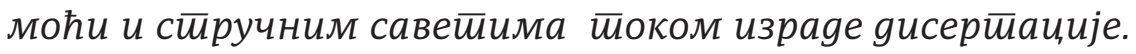

Захваљујем се йроф. gр Сиееви Пљеши, йроф. gр Душану

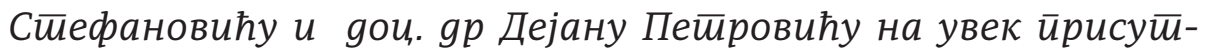
ном разумевању, савейима и йомоћи.

Посебно се захваљујем дои. gр Јанку Пејовићу, gр Свей-

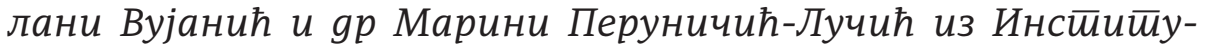
йа за Биохемију, Војномеgииинске Акаяемије на учињеним биохемијским анализама неоихооним за реализацију gокйорске gисерйације.

Великузахвалносй gуїујем ӣроф. gр Дубравку Бокоњићу, на о ввојеном времену, сииручној йомоћи и разумевању.

Захваљујем се ӣосебно йроф. gр Живаяину Буїарчићу и ӣроф. gр Влаgимиру Јаковљевићу који су ми йомоїли својим gраїоценим савейима и йодршком.

Захвалујем се свим члановима Клинике за недроло-

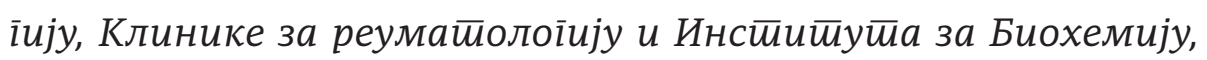
Војномеgицинске Акаяемије на йомоћи у раяу и ӣрикуйљању неойхоgних йоgайака.

Захваљујем се ӣријайељима на разумевању и йомоћи.

Највећу захвалносй gуїујем йородици а йосебно својој ћерки Кайарини и брайу йрим. gр Милораяу Рабреновићу, на безрезервној йоgршии и енеріији којом су ми олакшали израяу ове докйорске gисерйације. 


\section{I. Аутор}

Име и презиме:

Датум и место рођења:

Садашње запослење:

\section{II. Докторска дисертација}

Наслов:

Број страница:

Број слика:

Број библиографских података:

Установа и место где је рад израђен: Клиника за нефрологију, ВМА Клиника за реуматологију, ВMА Институт за био-хемију, ВМА

Научна област (УДК):

Ментор:

\section{III. Оцена и обрана}

Датум пријаве теме:

14.04 .2011

Број одлуке и датум прихватања докторске дисертације:

26/18 26.01.2012.

Комисија за оцену подобности теме и кандидата:

Проф. др Зоран Ковачевић, председник

Доц. др Дејан Петровић, члан

Проф. др Нада Пејновић, члан

Комисија за оцену докторске дисертације:

Проф. др Стево Пљеша, председник

Проф. др Душан Стефановић, члан

Доц. др Дејан Петровић, члан

Комисија за одбрану докторске дисертације:

Проф. др Стево Пљеша, председник

Проф. др Душан Стефановић, члан

Доц. др Дејан Петровић, члан 


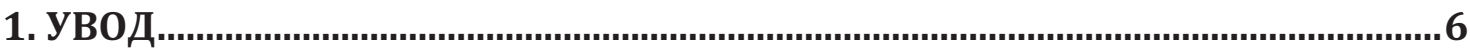

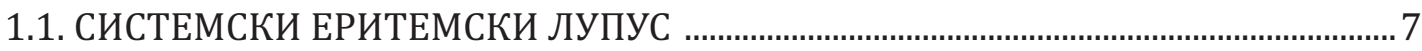

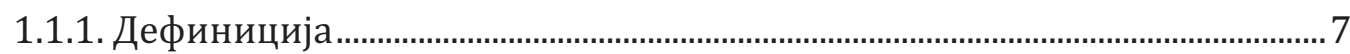

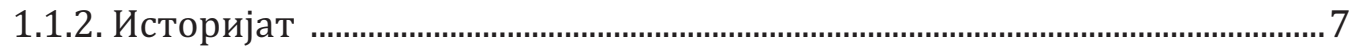

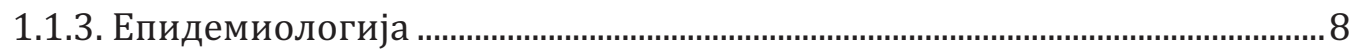

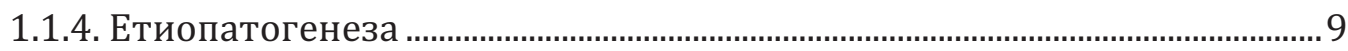

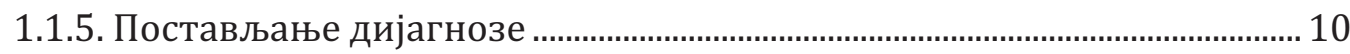

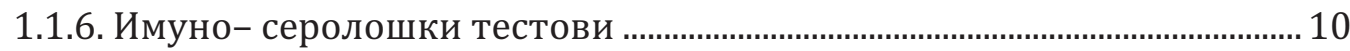

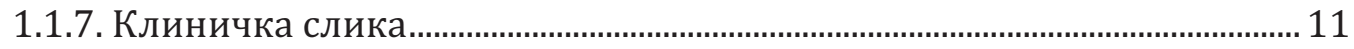

1.1.8. Лабораторијске анализе............................................................................. 12

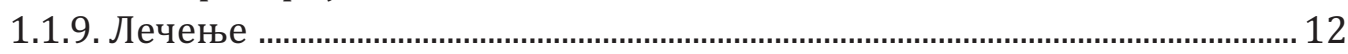

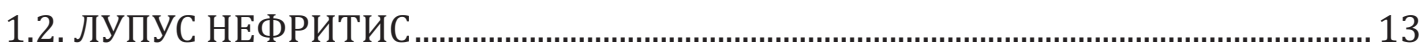

1.2.1. Дефиниција и патогенеза ......................................................................... 13

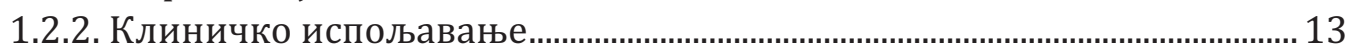

1.2.3. Пато-хистолошка класификација ЛН ......................................................... 14

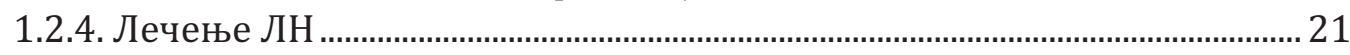

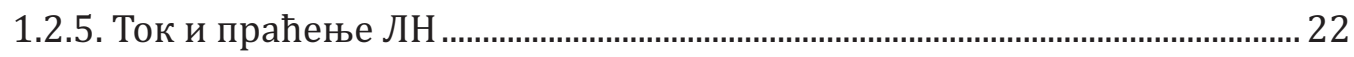

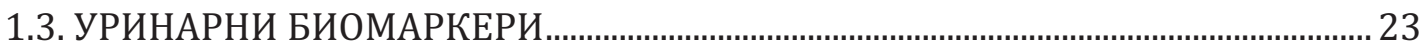

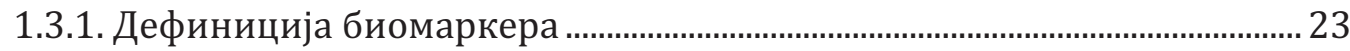

1.3.2. Основне карактеристике биомаркера …………………………….............. 24

1.3.3. Значај и одређивање уринарних биомаркера ......................................... 24

1.4. ЛИПОКАЛИН УДРУЖЕН СА НЕУТРОФИЛНОМ ГЕЛАТИНАЗОМ (НГАЛ) ....... 28

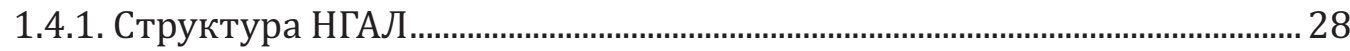

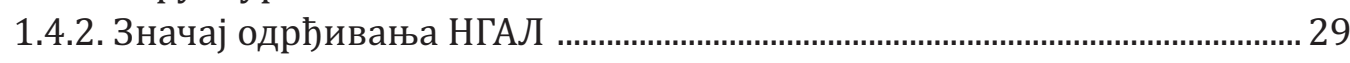

2. ЦИљ ИСТРАЖИВАЊА .......................................................................................... 37

2.1 ЦИљЕВИ И ХИПОТЕЗЕ ИСТРАЖИВАҢА .............................................................. 38

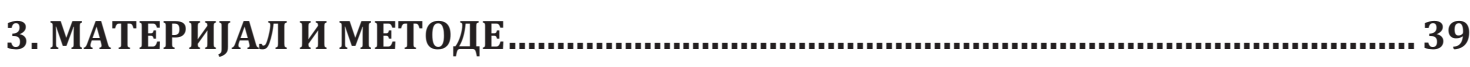

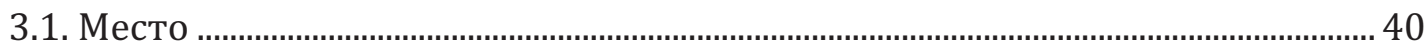

3.2. Испитиване групе................................................................................................. 40

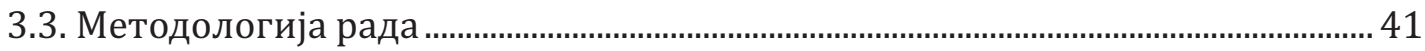

3.4. Статистичка обрада података .................................................................................. 42

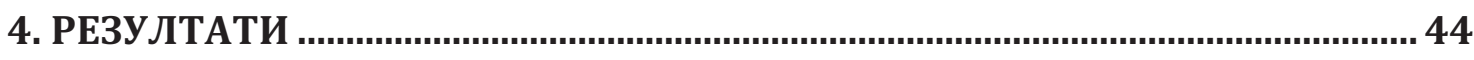

4.1. Демографски и лабораторијски резултати............................................................ 45 
4.1.1. Демографски подаци испитаника …………..................................................... 45

4.1.2. Лабораторијски резултати испитаника ....................................................... 45

4.1.3. Појединачни прикази лабораторијских параметара за болеснике обе групе .............................................................................................. 53

4.2. Поређење података унутар група по визитама..................................................... 59

4.2.1. Група 1/А: Поређење средњих вредности праћених лабораторијских параметара по визитама................................................ 59

4.2.2. Поређење средњих вредности праћених лабораторијских параметара по визитама у групи 2/Р .............................................................6 64

4.3. Поређење разлика између група 1/А и 2/Р .......................................................... 65

4.4. Корелације НГАЛ са одабраним лабораторијским параметрима

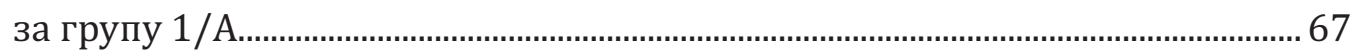

4.4.1. Корелација у/ НГАЛ са албуминима у групи 1/А по визитама .......... 67

4.4.2. Корелација у/ НГАЛ са анти дс ДНА антителима у групи 1/А

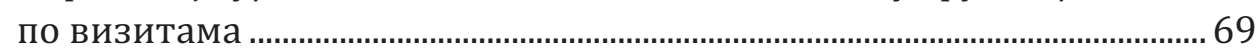

4.4.3. Корелација у/ НГАЛ са 24ч. протеинуријом у групи 1/А по

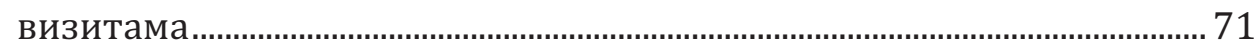

4.4.4. Корелација у/ НГАЛ са СЛЕДАИ/р у групи 1/А по визитама ................ 72

4.4.5. Корелација у/ НГАЛ са УП/кре у групи 1/А по визитама ........................ 74

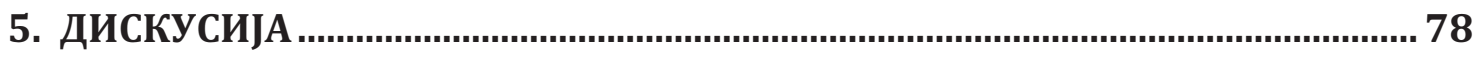

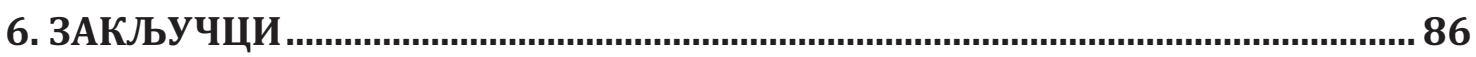

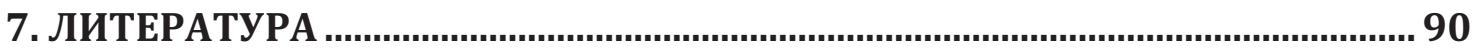

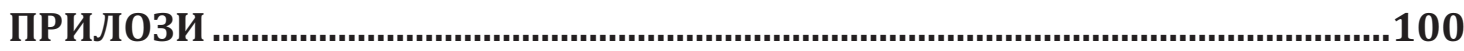


1. УВОД 


\section{1. СИСТЕМСКИ ЕРИТЕМСКИ ЛУПУС}

\subsection{1. Дефиниција}

Системски еритемски лупус (СЛЕ) је аутоимуно, мултисистемско обољење недовољно познате етиологије, хроничног тока, које се одликује продукцијом поликлонских аутоантитела, активацијом комплемента, депозитима имунских комплекса, а захвата све органске системе и ткива и испољава се најразличитијом симптоматологијом $(1,2)$.

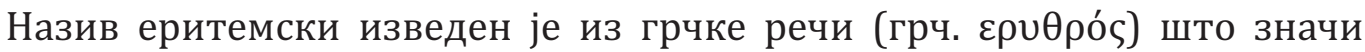
црвен, а односи се на црвену оспу по кожи, а реч лупус је изведена из латинске речи вук (лат. lupus) и односи се на лептирасту оспу на лицу сличну белим шарама на глави вука (3).

\subsection{2. Историјат}

Први опис „црвених улцерација” на кожи, које су можда представљале лупус, потиче од Хипократа још 400 год. п.н.е. Након њега у средњем веку термин лупус се користио за описивање црвених улцерација на лицу. Овај назив је први пут применио лекар Роџериус, око 1200 године, да би описао ерозивне лезије на лицу које су личиле на последице које оставља вук после напада (4-6). Француски лекар Pierre Cazenave 1851 год. је поменуо термин „lupus erythematosus”, а 1885 год. Sir William Osler описује промене на срцу, плућима, зглобовима, мозгу, бубрезима, желуцу, као и случајеве лупуса без кожних промена (4). 1872 год. Moritz Kaposi износи став да је лупус системска болест. Dr Thomas Payne је 1894 год. открио први лек, који је дао резултате у лечењу лупуса - кинин (chloroquine). 1898 год. започиње примена салицилата и кинина заједно, а овакав начин лечења је трајао до средине 20 века (4).1923 године - Emanuel Libman и Benjamin Sacks, описали су промене код системског еритемског лупуса на срцу познате као Либман-Саксов ендокардитис, као и бубрежне лезије и хематолошке поремећаје. Истовремено Paul Klemperer, по први пут за лупус уводи термин колагена болест. 1922 год. утврђено је да код око 30\% пацијената са лупусом постоји лажно позитиван тест на сифилис. 1946 год. откривене су Ле-ћелије (Dr Malcolm Hargraves). 1949-1950 год. започела је примена кортикостероида у лечењу СЛЕ од стране Dr Philip Hench-a, a ова група лекова се и данас користи у лечењу СЛЕ. Прва примена тестова за откривање антитела- антинуклеарних антитела (АНА) која су позитивна у 
више од 95\% пацијената са лупусом, почиње 1950 године. Десет година касније (1960 год.) заначајан напредак у лечењу лупуса чини откриће и примена циклофосфамида који је коришћен у комбинацији са кортикостероидима посебно у лечењу тежих форми СЛЕ (7). Осамдесетих година прошлог века још један значајан лек - циклоспорин у комбинацији са кортикостероидима почиње успешно да се примењује у лечењу аутоимуних болести и СЛЕ $(8,9,10)$. Након њега у лечењу СЛЕ почиње да се користи и такролимус, такође калцинеурински инхибитор, који је као и циклоспорин прво примењен у трансплантационој медицини, а након тога деведесетих година и у лечењу аутоимуних болести (11). Од лекова који су значајно утицали на лечење СЛЕ треба поменути и препарате Микофеноличне киселине, који су посебно нашли примену у одржавању ремисије СЛЕ (12). У новије време све је више студија са афирмативним резултатима у примени моноклонских антитела у лечењу СЛЕ и ЛН (13-16).

\subsection{3. Епидемиологија}

Инциденца СЛЕ је 4-7 болесника на 100.000 становника годишње, а преваленца 14,6-50,8/100.000 становника (17). Према Америчкој фондација за лупус 1,5-2 милиона Американаца има неки облик лупуса (18). Иако се болест јавља код оба пола, код жена је 9 пута чешћа, а јавља се обично од 15 до 45 године живота. Међутим после менопаузе и у раној младости однос полова је 3:1 (19). Код афро-америчких жена знаци болести су много тежи и прати их високи морталитет (20). Очекивано трајање живота ових болесника продужено је са 4-годишњег преживљавања од 50\% 1950 год., на 15-годишње преживљавање од 80\% данас. Код млађих болесника узрок смрти у року од 15 год. најчешће су инфекције, а после 35 год. најчешћи узрок смрти је инфаркт миокарда $(21,22)$. Инфективне болести су један од водећих узрока морбидитета и морталитета код лупуса, са уделом од 29\% свих смртних случајева код тих пацијената (23). Жене са лупусом између 35-44 година имају 52 пута већи ризик од инфаркта миокарда него жене млађег животног доба (22). Десетогодишња стопа преживљавања у појединим земљама у Азији и Африци је знатно нижа, и у распону је од $60-70 \%(23,24)$. 


\subsection{4. Етиопатогенеза}

И ако је етиологија СЛЕ и даље непозната, закључено је да постоје многи фактори који значајно утичу на процес ексцесивног стварања аутоантитела (25). У основи патогенезе СЛЕ је хиперреактивност Б лимфоцита, који због поремећаја имунског одговора прекидају толеранцију према антигенима сопственог ткива. Овакав абнормални одговор имунског система на формирање аутоантитела је условљен генетским предиспозицијама, факторима животне средине, хормонима и многим другим елементима $(26,27)$. Открића да је учесталост СЛЕ код идентичних близанаца (једнојајчаних) око $25-50 \%$, а код близанаца који су двојајчани око 5\% поврђују значајну улогу генетске предиспозиције (28). Велику улогу у развоју СЛЕ имају гени главног хистокомпатибилног комплекса (MНС) и то ХЛА класа - II, ДР2 и ДР3, који повећавају ризик за појаву СЛЕ. У овим класама се јављају чешће аутоантитела типа анти См, анти Ро, анти Ла, анти РНП и анти ДНА антитела $(29,30)$. Гени ХЛА класе III, посебно они који имају улогу у кодирању Ц2 и Ц4 компоненте комплемента, повећавају ризик за настанак СЛЕ. Утврђена је и повезаност СЛЕ са наследном дефицијенцијом Ц1-ку, Ц1 p/с и Ц 2 компонентом комплемента $(31,32)$. Чињеница да је учесталост ове болести већа код жена подвлачи значај хормона у настанку СЛЕ $(33,34)$.

Улога фактора животне средине као што су стрес, излагање ултраљубичастом зрачењу (сунцу), пушење, лекови (посебно антибиотици сулфо и пеницилинске групе), инфекције (цитомегаловируси, парвовируси, хепатитис Ц, Епштајн-Бар вирус), излагања хемијским једињењима (трихлоретилен, силицијум, пестициди, жива и друге материје из воде и прашине) су такође повезани са настанком СЛЕ (35-38).

Постоје различите теорије о механизму настанка лезија. Сматра се да антитела која се стварају на антигене ћелијске мембране, доводе до лизе ћелија активирајући систем комплемента или доводећи до фагоцитозе од стране мононуклераног фагоцитног система. Доказано је да постоји и транслокација интрацелуларних антигена на површину ћелије за које се везују специфична аутоантитела која покрећу механизме лизе ћелија. Та аутоантитела највероватније модификују рецепторе на ћелијској мембрани и покрећу ћелијску цитотоксичност. Најприхваћенији механизам оштећења је посредован имунским комплексима (ИК) које чине аутоантитела везана за антиген, која ослобођена у циркулацију или ин-ситу, последично активирају систем комплемента и покрећу процесе запаљења и оштећења ћелија $(17,39)$. 


\subsection{5. Постављање дијагнозе}

Дијагнозу СЛЕ постављамо на основу јединствених дијагностичких критеријума прихваћених у целом свету. То су критеријуми Америчке реуматолошке асоцијације (APA) - (ARA Criteria for SLE diagnosis) из 1982, ревидирани 1997 год. (40, 41). За постављање дијаганозе потребно је да постоје било која 4 или више, од 11 критеријума истовремено или у било ком интервалу посматрања. Критеријуми су:

- Осип на јагодицама лица

- Дискоидни осип

- Фотосензитивност

- Улцерације у усној шупљини

- Артритис

- Серозитис

- Бубрежни поремећај (активни седимент, протеинурија)

- Неуролошки поремећај

- Хематолошки поремећаји

- Имунолошки поремећаји

- Антинуклеарна антитела

\subsection{6. Имуно- серолошки тестови}

Главна карактеристика СЛЕ је постојање великог броја разноврсних аутоантитела, данас се сматра да их има више од 100 , а нека од њих су присутна у високом титру $(40,41)$. Најзначајнија аутоантитела су:

- Антинуклеусна антитела (АНА),

- ДНК (једноланчана и дволанчана),

- Дезоксинуклеопротеин (ЛЕ фактор),

- Хистони,

- Комплекс Хистон -ДНК,

- Нуклеусни гликопротеин,

- Нуклеусни РНК,

- Антикардиолипинска антитела (АЦА),

- Антитела против саставних делова цитоплазме РНК, митохондрија и рибозома,

- Антитела против леукоцита, еритроцита, тромбоцита, фактора коагулације, 
- Антитела одговорна за лажно позитивне резултате тестова на Луес, токсоплазмозу,

- Остала антитела: Реуматоидни фактор (РФ: ИгГ, ИгМ), органотропна (антитела на ткиво тиреоидеје) и многа друга.

\subsection{7. Клиничка слика}

СЛЕ је генерализована болест, код које је основна лезија дифузни васкулитис, који настаје таложењем комплекса антиген-антитело и комплемента. Клиничка слика је различита, индивидуална, као и иницијална симптоматологија, а то је један од разлога да се у постављању дијагнозе СЛЕ и даље губи драгоцено време (41-43). У Табели 1 приказане су неке од најучесталијих абнормалности и њихова процентуална заступљеност код СЛЕ .

Табела 1 - Најучесталије абнормалности које се сусрећу код СЛЕ (41)

\begin{tabular}{|l|c|}
\hline Малар раш & $50 \%$ \\
\hline Дискоидни раш & $10-30 \%$ \\
\hline Фотосензитивност & $15-40 \%$ \\
\hline Оралне и назофарингеалне улцерације & $15-25 \%$ \\
\hline Артритис неерозивни & $90 \%$ \\
\hline Плеуритис & $50-60 \%$ \\
\hline Перикардитис & $20-25 \%$ \\
\hline Перзистентна протеинурија > 0,5 гр/дн & $50-70 \%$ \\
\hline Цилиндрурија (еритроцитни цил.) & $30-40 \%$ \\
\hline Неуробиолошке манифестације - грчеви & $10 \%$ \\
\hline Психоза & $15 \%$ \\
\hline Хемолитичка анемија са ретикулоцитозом & $10 \%$ \\
\hline Леукоцитопенија < 4000 /mm ${ }^{3}$ & $40-50 \%$ \\
\hline Лимфоцитопенија <1500 /mm ${ }^{3}$ & $60-80 \%$ \\
\hline Тромбоцитопенија <100,000 /mm ${ }^{3}$ & $20-30 \%$ \\
\hline Анти Дс ДнА антитела & $60-90 \%$ \\
\hline См антитела & $10-30 \%$ \\
\hline Антикардиолипинска антитела & $44 \%$ \\
\hline Антинуклеусна антитела & $>95 \%$ \\
\hline
\end{tabular}


Акутни облик СЛЕ се карактерише наглим почетком и брзим током уз малаксалост, болове у зглобовима, мишићима, црвенилом на образима и корену носа, нефритисом, полисерозитисом, пнеумонијском инфилтрацијом, тахикардијом, поремећајем срчаног ритма, лимфаденопатијом, хепатоспленомегалијом, делиријумом, комом (44). Летални завршетак често наступа после неколико недеља код нелечених случајева или прелази у хронични облик. Хронични облик почиње постепено, болест траје годинама, са повременим погоршањима и побољшњима (17).

\subsection{8. Лабораторијске анализе}

У лабораторијским анализама најчешће се запажају повишени неспецифични параметри запаљења (Ц реактивни протеин - ЦРП, седиментација - СЕ, фибриноген, алфа 2 глобулин). У крвној слици може се запазити панцитопенија или понекад само појединачно смањење тромбоцита, еритроцита или леукоцита. Често већ на самом почетку болести постоје елементи бубрежног оштећења (активан уринарни седимент, протеинурија, а у серуму повишен креатинин, уреја, смањен ниво укупних протеина, албумина, клиренса креатинина). Наилазимо и на поремећаје параметара коагулације: продужено активирано протромбинско време - аПТT, снижен антитромбин III - AT3. Имунски параметри су измењени: присутна је хипокомплементемија Ц3, Ц4, позитивне лупусне ћелије - ЛЕ, позитивна Антинуклеусна антитела - АНА, позитивна анти-двострукоспирална Дезоксирибонуклеарна антитела - анти дс-ДНА антитела, позитивна антикардиолипинска антитела - АЦА (уколико је присутан и секундарни антифосфолипидни синдром $(41,42,43)$.

Понекад, у ретким ситуацијама АНА могу бити негативна, при чему клиничка слика указује на СЛЕ. Тада уколико су позитивна анти ССА (Ро) антитела, постоји могућност да болесник има „АНА - негативни“ СЛЕ који је иначе доста редак. Сматра се да око 62\% болесника са „АНА - негативним” СЛЕ, има присутна анти ССА антитела (17).

\subsection{9. Лечење}

Основни циљ лечења је брзо постизање и што дуже одржавање ремисије СЛЕ (45). Данас се СЛЕ лечи кортикостероидима (КС), циклофосфа- 
мидом (ЦУЦ), азатиприном (АЗА), препаратима микофеноличне киселине (ММФ), циклоспорином (ЦСА), такролимусом (ТАК) и у последње време све више моноклонским антителима. Значајно је и коришћење антималарика, имуноглобулина, терапијских измена плазме као и остале симптоматске терапије (заштита од зрачења, анти-улкусни лекови, профилакса антибиотицима итд). За успешно лечење обавезне су редовне контроле и праћење биохемијских и имунских анализа (7-17).

\section{2. ЛУПУС НЕФРИТИС}

\subsection{1. Дефиниција и патогенеза}

Када СЛЕ у прогресији, захвати бубреге долази до испољавања најтеже клиничке манифестације ове болести, која се зове лупус нефритис (ЛН). Иако патогенеза ЛН није још увек у потпуности разјашњена, сматра се да настаје услед нагомилавања имунских комплекса (ИК) посредованих најразличитијим аутоантителима међу којима је и анти дс ДНА. Као последица тога развија се акутни инфламаторни и имунолошки одговор. То подразумева активацију леукоцита, изменуу њиховим имунобиолошким особинама због чега долази до стварања цитокина и фактора раста. Овај одговор је праћен хроничном фазом у којој се стварају депозити колагена и екстрацелуларних макромолекула који доприносе настанку фиброзних промена у бубрегу (46-48).

\subsection{2. Клиничко испољавање}

ЛН је једна од најтежих манифестација СЛЕ, па често у тренутку његове дијагностике код болесника постоје већ испољени симптоми као што су малаксалост, повишена температура, кожне промене, артралгије, миалгије, полисерозитис, неуролошки симптоми, повишен артеријски притисак, поремећај срчаног ритма, гастроинтестиналне тегобе и многи други симптоми $(17,49)$.

Понекад ЛН може бити асимптоматски, па на њега упућују само лабораторијске абнормалности и такав ток виђамо код мезангиопролиферативног и мембранског ЛН. Активни нефритис и појаву периферних едема услед развоја 
нефротског синдрома виђамо код дифузно-пролиферативног ЛН и мембранског ЛН (50). Када доминира артеријска хипертензија, главобоља, поремећаји вида, кардијална декомпензација обично постоји дифузни-пролиферативни ЛН. У лабораторијским анализама осим осталих параметара активног СЛЕ наилазимо и на поремећај у параметрима бубрежне функције: повишени креатинин и уреја у серуму, снижен клиренс креатинина, активан седимент урина (еритроцитурија, леукоцитурија, цилиндрурија) као и повећање 24ч. протеинурије (51).

\subsection{3. Пато-хистолошка класификација лН}

Пато-хистолошке манифестације ЛН могу бити различите, а болест захвата све структуре бубрега - гломеруле, тубуле, интерстицијум и крвне судове. Биопсија бубрега је данас уобичајена код болесника са активним нефритисом, а посебно у првој епизоди. Многи клиничари сматрају да због сличности у испољавању различитих класа лупус нефритиса, рана биопсија бубрега има велики значај у терапији и прогнози болести $(52,53)$.

Имајући у виду значај биопсије бубрега, група аутора је дала предлог индикације за биопсију бубрега у ЛН $(50,53)$.

1. развој акутне бубрежне инсуфицијенције,

2. протеинурија > 500 мг/24 ч. или однос: ниво Кр > 0,5 гр протеина / гр креатинина,

3. хематурија уз протеинурију било ког нивоа,

4. цилиндрурија / Ер цилиндри, Ле цилиндри или ћелијски цилиндри/,

5. бубрежна инсуфицијенција која је одговорила на терапију али има честе релапсе

Патохистолошка верификација ЛН је веома значајна у избору модалитета лечења и у даљој прогнози па је Светска Здравствена Организација (С30) ради лакшег проучавања, ЛН класификовала први пут 1982. год., а након тога је учињена ревизија те класификације 1995год. (52- 56) (Табела 2). 
Табела 2 - СЗО класификација ЛН на основу налаза светлосне, имунофлуоресцентне, и електронске микроскопије (модификована 1995. год) (56).

\begin{tabular}{|c|c|}
\hline \multicolumn{2}{|c|}{ Патохистолошка класификација Лупус нефритиса СЗО /мод. 1995. год./ } \\
\hline Класа I & $\begin{array}{l}\text { Нормални гломерули у светлосној (СМ), имунофлуоресцентној (ИФ) и } \\
\text { електронској микроскопији (ЕМ). }\end{array}$ \\
\hline Класа II & $\begin{array}{l}\text { Мезангијалне лезије } \\
\text { А) нормални налаз у СМ, мезангијални депозити у ИФ, и /или ЕМ } \\
\text { Б) мезангијална хиперцелуларност и депозити у ИФ,и/или ЕМ. }\end{array}$ \\
\hline Класа III & $\begin{array}{l}\text { Фокално сегментни гломерулонефритис } \\
\text { А) активне некротизирајуће лезије } \\
\text { Б) активне и склерозирајуће лезије } \\
\text { В) склерозирајуће лезије }\end{array}$ \\
\hline Класа IV & $\begin{array}{l}\text { Дифузни гломерулонефритис (мезангијална, ендокапиларна или мезанги- } \\
\text { окапиларна пролиферација и/или експанзивни субендотелни депозити)) } \\
\text { А) без сегментних лезија } \\
\text { Б) са активним некротизирајућим лезијама } \\
\text { В) са активним и склерозирајућим лезијама } \\
\text { Г) са склерозирајућим лезијама }\end{array}$ \\
\hline Класа V & $\begin{array}{l}\text { Дифузни мембранозни гломерулонефритис } \\
\text { А) чисти мембранозни гломерулонефритис } \\
\text { Б) удружен са лезијама класе II и IV }\end{array}$ \\
\hline Класа VI & Узнапредовали склерозирајући гломерулонефритис \\
\hline
\end{tabular}

2004 године формулисана је још једна класификација од стране експертске групе патолога, реуматолога и нефролога, а под покровитељством Интернационалне Асоцијације Нефролога (International Society of Nephrology - ISN) и Удружења нефро-патолога. (Renal Pathology Society - RPS) (Табела 3). Према овој класификацији ISN/RPS обавезно је и одређивање индекса активности и хроницитета ЛН (55-57). 
Табела 3 - ISN/ RPS Патохистолошка класификација Лупус нефритиса 2004. год. (57)

Патохистолошка класификација Лупус нефритиса: ISN/ RPS 2004 год.

\begin{tabular}{|c|c|}
\hline Класа I & $\begin{array}{l}\text { Минимални мезангијални ЛН - Нормални гломерули у светлосној } \\
\text { микроскопији (СМ), али са мезангијалним имуним депозитима у } \\
\text { имунофлуоресцентној микроскопији (ИФ). }\end{array}$ \\
\hline Класа II & $\begin{array}{l}\text { Мезангијално пролиферативни ЛН - Мање изражена мезангијална хипер- } \\
\text { целуларност или мезангијална експанзија у СМ са мезангијалним имуним } \\
\text { депозитима. Изоловани субепителијални или субендотелијални депозити } \\
\text { виђени ИФ или ЕМ али не СМ }\end{array}$ \\
\hline Класа III & $\begin{array}{l}\text { Фокални ЛН - Активне или неактивне фокално, сегментне или глобал- } \\
\text { но ендо или екстракапиларни ГН са захватом <50\% од свих гломерула, } \\
\text { типично са фокално субендотелијалним имуним депозитима, са или без } \\
\text { мезангијалног захватања } \\
\text { Класа III А: активне лезије: фокално пролиферативни Лн } \\
\text { Класа III Б: активне и хроничне лезије: фокално пролиф. и склерозирајући } \\
\quad \text { Лн }\end{array}$ \\
\hline
\end{tabular}

Класа III Ц: хроничне инактивне лезије са гломерулском склерозом; Фокално склерозирајући ЛН

Дифузни ЛН - Активни или инактивни дифузно сегментно или глобално ендо или екстракапиларни ГН са захватом >/= 50\% свих гломерула, типично са дифузним субендотелијалним имуним депозитима, са или без мезангијалне алтерације. Ова класа је подељена у дифузни сегментни (IV-S) када >/= 50\% захваћених гломерула има сегментне лезије, дифузни глобални IV-G када >/= 50\% од захваћених гломерула има глобалне лезије. Сегментно се дефинише као лезија која захвата мање од пола гломерула Ова класа укључује и случјеве са „,wire loop deposits, али са мало или без гломерулске пролиферације.

Класа IV Класа IV-C (A): Активне лезије: дифузно сегментни пролиф. ЛН.

Класа IV-Г (A): Активне лезије: дифузни глобално пролиф. ЛН.

Класа IV-C (A/Ц): Активне и хроничне лезије: дифузни сегмен. пролиф. и склероз. ЛН

Класа IV-Г(А/Ц): Активне и хроничне лезије: дифузни глобално пролиф. и склероз. ЛН

Класа IV-C(Ц): Хроничне инактивне лезије са склерозом: дифузни сегмеп. склероз. ЛН

Класа IV-Г(Ц): Хроничне инактивне лезије са склерозом: дифузно глобално склероз. ЛН

Мембрански гломерулонефритис - Глобално или сегментно субепителијални имуни депозити, имуне или морфолошке промене на СM Класа V у комбинацији са класом III или IV и у том случају обе се дијагностикују. Класа V може имати различит степен мезангијалне хиперцелуларности и може имати узнапредовалу склерозу.

Класа VI

Узнапредовали склерозирајући ЛН

>/= 90\% од гломерула са глобалном склерозом без резидуалне активности 
Петогодишње ренално преживљавање у Класи II је веће од 90 \%, у Класи III износи 85-90\%, у Класи IV је 60-90\%, а у Класи V је 70-90\%.

ЛН није статички процес, познато је да се трансформише услед терапије или спонтано, па је на ре-биопсијама то утврђено у $14-40 \%$ болесника $(58,59)$. Пато-хистолошке класификације подразумевају и одређивање индекса активности и хроницитета лупус нефритиса као предиктора прогнозе оштећења бубрега. Први Индекс ЛН, је формулисан од стране Pirani i Morel-Maroger-a, a касније ревидиран и допуњен од стране Austin i Balow-а и назван је: Индекс активности и хроницитета ЛН, Националног Института Здравља (National Institutes of Helth -NIH (Табела 4) (59).

Табела 4 - Индекс активности и хроницитета ЛН

\begin{tabular}{|c|c|c|c|}
\hline \multicolumn{4}{|c|}{ ИНДЕКС АКТИВНОСТИ И ХРОНИЦИТЕТА ЛУПУС НЕФРИТИСА } \\
\hline \multicolumn{2}{|l|}{$\begin{array}{c}\text { ИНДЕКС АКТИВНОСТИ } \\
(0-24)\end{array}$} & \multicolumn{2}{|c|}{$\begin{array}{c}\text { ИНДЕКС ХРОНИЦИТЕТА } \\
(0-12)\end{array}$} \\
\hline Хиперцелуларност гломерула & 3 & \multicolumn{2}{|l|}{ Гломерулске лезије } \\
\hline Леукоцитна инфилтрација & 3 & Склероза гломерула & 3 \\
\hline Кариорекса/ фибрионидна некроза/ & $3(2 X)$ & Фиброзни полумесеци & 3 \\
\hline Ћелијски полумесеци & $3(2 X)$ & \multicolumn{2}{|c|}{ Тубулоинтерстицијумске лезије } \\
\hline Хијалини тромби & 3 & Атрофија тубула & 3 \\
\hline Тубулоинтерстицијска инфламација & 3 & Фиброза интерстицијума & 3 \\
\hline
\end{tabular}

Индекс активности (ИА) подразумева запаљенске и пролиферативне промене у бубрегу у току ЛН, у моменту када је учињена биопсија и реверзибилан је. На премену ИА утиче спроведено лечење, а код већег степена ИА се увек препоручују агресивнији терапијски протоколи $(58,59)$. Индекс хроницитета (ИХ) означава склерозу, атрофију и фиброзу тако да већи ИХ значи и слабији одговор на лечење. Клиничко патолошке студије јасно указују да је фиброза гломерула, крвних судова а посебно у интерстицијуму, увек показатељ терминалног бибрежног оштећења (59).

На следећим сликама (Слике 1-8) приказане су типичне пато-хистолошке промене у бубрегу код различитих класа ЛН (58). 
Слика 1 - ЛН тип II: CM -мезангијална хиперцелуларност гломерула - бојење PAS (periodic-acid Schiff).

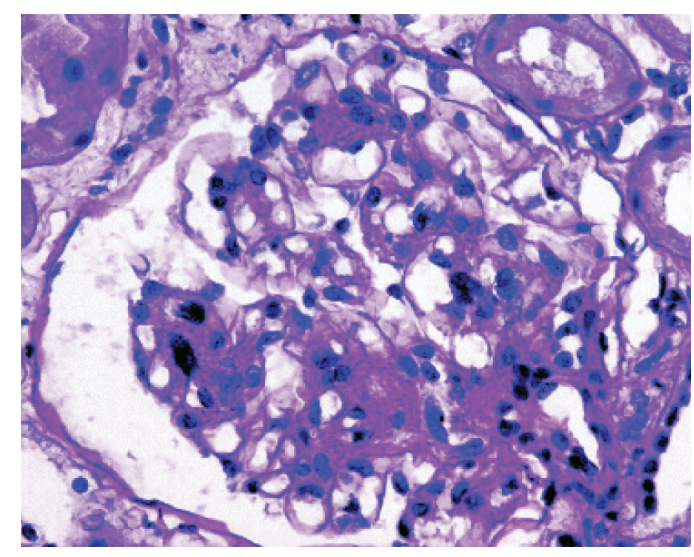

Слика 2 - ЛН тип III: СМ приказује гломерул који има сегментну ендокапиларну хиперцелуларност, мезангијалну хиперцелуларност, задебљање капиларног зида и сегментну капиларну некрозу (метенамин сребро).

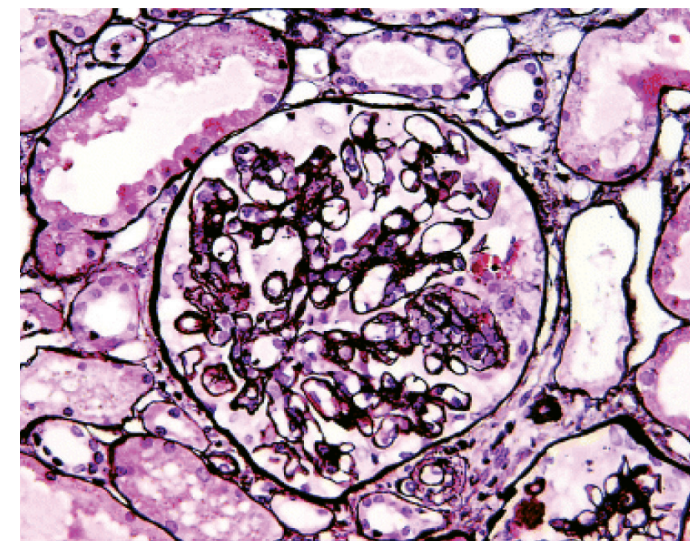

Слика 3 - ЛН тип IV/ IV-Г(A): CM приказује гломеруле са глобалном ендокапиларном и мезангијалном хиперцелуларношћу и експанзијом матрикса, са леукоцитима и двоструким контурама (метенамин сребро).

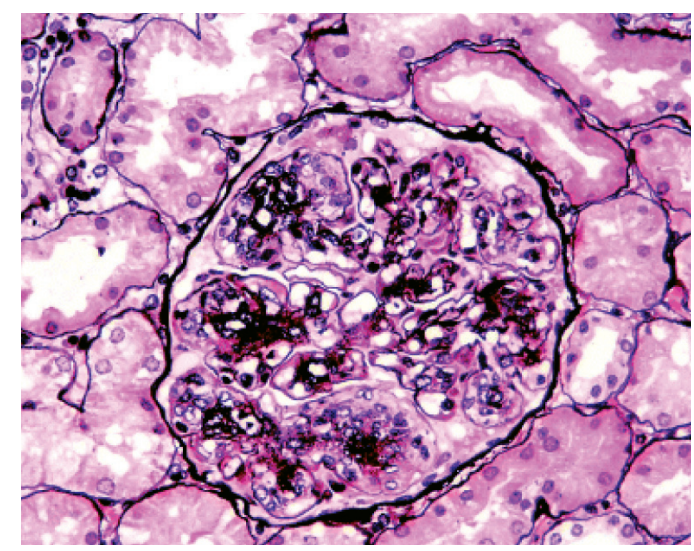


Слика 4 - ЛН тип IV/ IV-C(A): CM приказује део гломерула са ендокапиларном хиперцелуларношћу, зид капилара који је са двоструком контуром, „wireloop“ лезију и хијалини тромб (бојење PAS).

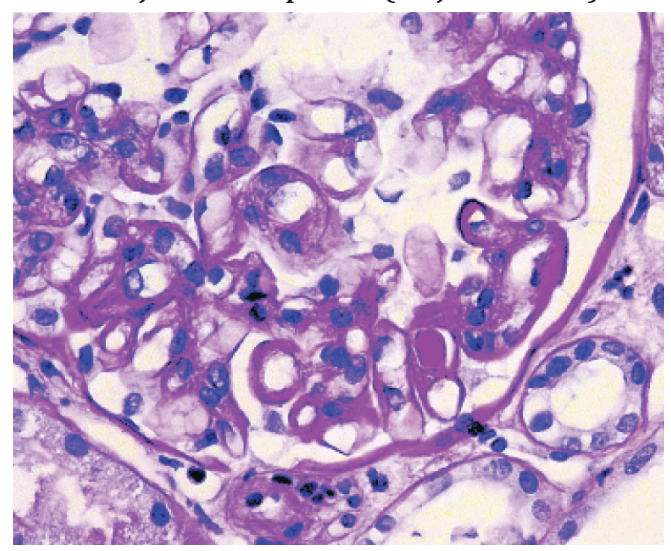

Слика 5 - ЛН тип IV/ IV-Г(A/Ц): СМ приказује гломерул са израженом екстракапиларном пролиферацијом, „wireloop” лезијама, леукоцитном инфилтрацијом, апоптозом, капиларном некрозом уз експанзију хиперцелуларног матрикса и значајну интерстицијску инфламаторну инфилтрацију (бојење PAS)

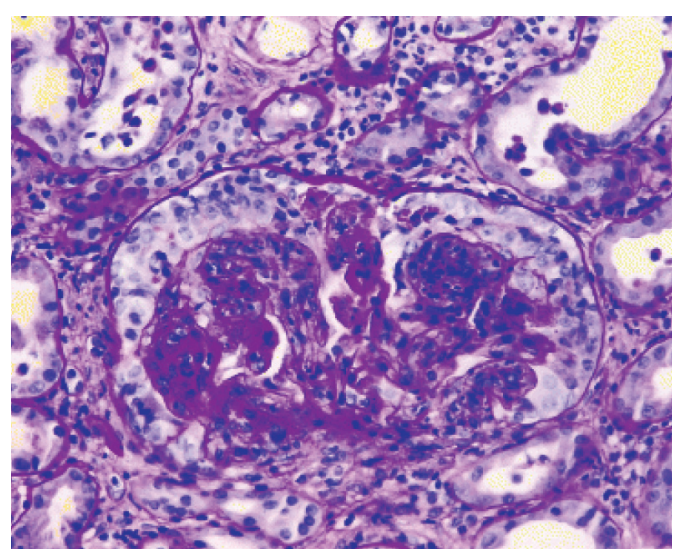

Слика 6 - ЛН тип IV/ IV-Г(A/Ц): Гломерул са глобалном ендокапиларном пролиферацијом, леукоцитном инфилтрацијом, дуплих контура ca „crescent” формацијама, трансформацијом тубула, почетном склерозом и нарушавањем Бовманове капсуле (бојење PAS).

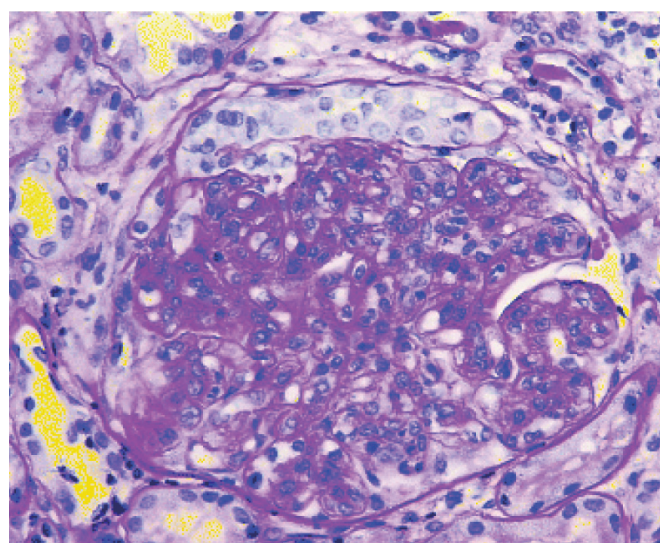


Слика 7 - ЛН тип IV/ IV-Г(A): Гломерул са израженим субендотелијалним имуним депозитима - „wireloop” лезијама, формирањем нове базалне мембране са унутрашње стране капилара, без ендокапиларне леукоцитне инфилтрације или хиперцелуларности (метенамин сребро)

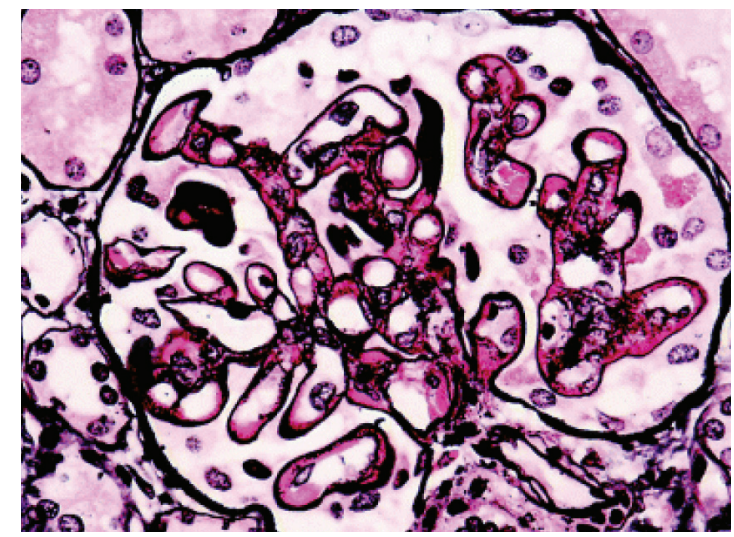

Слика 8 - ЛН тип V: Гломерул са одмаклим стадијумом мембранског ЛН, са масивном субепителијалном акумулацијом имунских депозита и „spike“ формацијама (метенамнин сребро).

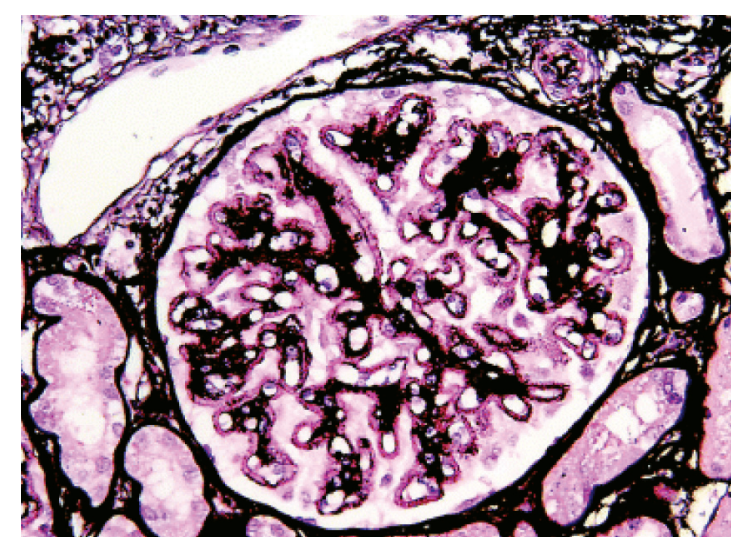

Слика 9 - ЛН тип IV и V (A/Ц): Гломерул са мембранским ЛН и субепителијалним „spike” формацијама, глобалном ендокапиларном и мезангијалном хиперцелуларношћу, слабије израженим „сrescent” формацијама и слабијом израженом мезангијалном и капиларном склерозом (метенамин сребро).

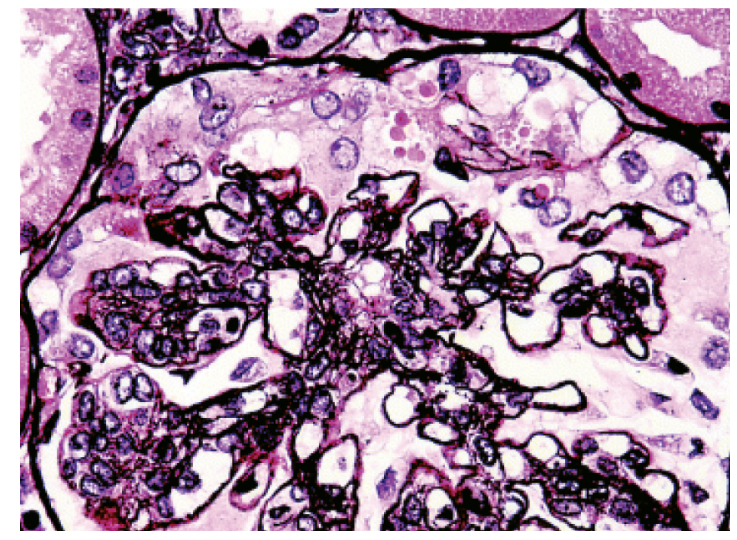




\subsection{4. Лечење ЛН}

У зависности од степена оштећења бубрега односно Класе ЛН, постоје и препоруке за лечење, односно примену различитих терапијских модалитета. Раније су чешће коришћене препоруке C30 (56-58,59), а у последњих година користе се Препоруке за лечење бубрежних болести ИСН - КДИГО (Clinical Practice Guideline for Glomerulonephritis - KDIGO) (Табела 5).

Табела 5 - КДИГО- препоруке за лечење у зависности од класе ЛН (60)

\begin{tabular}{|c|c|c|}
\hline Класа I & Миним. мезангиј. ЛН & $\begin{array}{l}\text { Без специфичне терапије - лечење екстра- } \\
\text { реналних манифестација }\end{array}$ \\
\hline Класа II & Мезангиално-пролифер. ЛН & $\begin{array}{l}\text { Без специфичне терапије - уколико је } \\
\text { протеинурија < 1гр/24ч - лечење екстраре- } \\
\text { налних манифестација. } \\
\text { - Уколико је протеинурија > } 3 \text { гр/24ч. } \\
\text { - кортикостероиди (КС) или калцинеу- } \\
\text { рински инхибитори (КНИ) }\end{array}$ \\
\hline Класа III & Фокално пролифер. ЛН & $\begin{array}{l}\text { ИНИЦИЈАЛНА: КС } 1 \text { мг/кг + ЦуЦ / и.в. } \\
\text { 0,5-1 г/м2 мес. - } 6 \text { мес. или и.в. } 500 \text { мг на } \\
2 \text { нед. - } 3 \text { мес., или ММФ / } 3 \text { г/дн. - } 6 \text { месеци, } \\
\text { ОДРЖАВАЈУЋА: АЗА/1.5-2.5 мг/кг/дн. или } \\
\text { ММФ/1-2 г/дн. уз КС /10 мг/дн. или } \\
\text { КНИ са КС / мале дозе / }\end{array}$ \\
\hline Класа IV & Дифузно пролифер. ЛН & $\begin{array}{l}\text { ИНИЦИЈАЛНА: КС } 1 \text { мг/кг + ЦуЦ и.в. } \\
\text { 0,5-1 г/м, } 2 \text {-6 мес.(NIH) или и.в. } 500 \text { мг } \\
\text { на } 2 \text { нед. - } 3 \text { мес.(Euro-Lupus), или } \\
\text { ММФ / } 3 \text { г/дн. - } 6 \text { месеци, } \\
\text { оДРЖАВАЈУЋА: АЗА /1.5-2.5 мг/кг/дн. или } \\
\text { ММФ/1-2 г/дн. уз КС /10 мг/дн. или } \\
\text { КНИ са КС /мале дозе /. }\end{array}$ \\
\hline Класа V & Мембрански ЛН & $\begin{array}{l}\text { - Ако имају нормалну функ. бубрега и } \\
\text { ненефротску протеин. - имуносупресиви } \\
\text { само због екстрареналних манифестација. } \\
\text { - Ако имају перзист. нефротску прот.: } \\
\text { КС + ЦуЦ или КНИ, или АЗА, или ММФ. }\end{array}$ \\
\hline Класа VI & $\begin{array}{l}\text { Узнапредовали } \\
\text { склерозирајући ЛН }\end{array}$ & $\begin{array}{l}\text { КС и имуносупресивна терапија само због } \\
\text { екстрареналних манифестација }\end{array}$ \\
\hline
\end{tabular}

КДИГО препоруке подразумевају опште препоруке за лечење болесника са гломерулопатијама: хигијенско-дијетски режим живота и исхране, лечење 
хипертензије, хиперлипидемије, хиперкоагулабилности, терапију диуретицима и осталу симптоматску терапију. Такође, сви болесници са ЛН, би требали без обзира на класу ЛН, да добијају и хидроксихлорокин (hydroxychloroquine), у дози од 6-6,5 мг/кг/т.тежине, уколико нема контраиндикација за овај лек (60). Уколико је присутан и антифосфолипидни синдром препоруке КдИГО су да је обавезна антикоагулантна терапија којом се постиже циљни ИНР (international normalized ratio-INR) 2-3 ИЈ (60).

У лечењу релапса ЛН (који означава промену у седименту урина, повећање протеинурије, погоршање кл. креатинина, а смањење нивоа комплемента уз повећање анти дс-ДНА антитела које може бити присутно, али није обавезно) после комплетне или парцијалне ремисије, користимо прво индукциону, а након тога терапију одржавања, која је била ефикасна у претходном лечењу. Посебна пажња се поклања кумулативној дози Циклофосфамида и по потреби користи протокол без њега (60).

У случају поновних релапса разматра се поновна биопсија бубрега, посебно ако постоји сумња да се патохистолошка класа ЛН променила, односно да се појавило погоршање бубрежне функције или повећање протеинурије.

У случају ЛН резистентног на терапију (погоршање бубрежне функције или повећање протеинурије) разматра се поновна биопсија бубрега због сагледавања активности односно хроницитета лезије бубрега. Уколико је болест активна примењују се алтернативни третмани као на пример моноклонским антителима (rituximab), имуноглобулинима или КНИ (60).

Последњих година све је већи број студија које указују на повољан ефекат моноклонских антитела - анти ЦД 20 антитела, анти ЦД 22 антитела, анти Б лимфоцитних стимулатора и осталих (61).

\subsection{5. Ток и праћење лн}

Појава ЛН-а представља врло лош прогностички параметар код болесника са системским еритемским лупусом. Болесници са ЛН, лече се дуготрајно и веома пажљиво због склоности ка релапсима и егзацербацијама. Лоши прогностички фактори за болеснике са ЛН су појава нефротског синдрома, иницијално испољавање бубрежне инсуфицијенције, слаб одговор на примењено лечење. Патохистолошки лошију прогнозу имају болесници са испољеном атрофијом тубула, интерстицијском фиброзом, израженом гломерулском склерозом, 
артеритисом и некротизирајућим артериолитисом. То подвлачи велики значај правовременог постављања дијагнозе ЛН и започињања лечења.

Досадашњи биохемијско - имунски параметри за одређивање активности болести су недовољни, а њихова корист контроверзна. Зато је у пракси златни стандард за одређивање активности ЛН биопсија бубрега $(50,52,53,62)$.

Да би праћење ЛН било успешно није довољно учинити једну биопсију бубрега, већ се предлажу понављане биопсије бубрега. Међутим такве серијске - ребиопсије бубрега којима би пратили активност ЛН, успешност лечења или егзацербацију, рутински не користимо у клиничкој пракси из много разлога. Метода је болна, некомфорна за пацијента, могуће су и компликације $(62,63)$. Из свакодневне праксе у току праћења пацијената и без биопсије бубрега могуће је утврдити знаке активности болести који су уједно и лоши прогностички знаци ЛН. Лош прогностички знак била би припадност црној раси, изражена анемија, пораст серумског креатинина, изражена протеинурија, а на пато-хистолошком препарату: изражен степен хроницитета, бројне целуларне крешчент формације и интерстицијска фиброза. Последњих година преовладава мишљење да стандардно праћење бубрежне функције коришћењем серумског креатинина, није адекватно јер значајна оштећења бубрега настају пре функционог оштећења односно пре него што дође до пораста креатинина у серуму (59).

\section{3. УРИНАРНИ БИОМАРКЕРИ}

\subsection{1. Дефиниција биомаркера}

Биомаркери су супстанце или једињења која означавају биолошко стање, односно изражавају болест (64). Њих карактеришу биолошка својства на основу којих можемо да их откријемо и измеримо у крви, урину или другим телесним течностима и ткивима (64). На тај начин својим присуством биомаркери указују на нормално стање, или на разне биолошке процесе, односно указују на присутно патолошко стање, на клинички или терапијски одговор у лечењу и на друге значајне промене. 
Дефиниција биомаркера према Америчкој Агенцији за контролу лекова и хране - ФДА (US Food and Drug Administration) је да су то: „било који дијагностички индикатори који се могу измерити и који се могу искористити да покажу ризик или присуство болести" (65). Биомаркери могу бити молекули, ћелије, гени, генски продукти, ензими, хормони и многи други протеински партикли.

\subsection{2. Основне карактеристике биомаркера}

Добар биомаркер мора да омогући информације које ће убрзати дијагностику или је учинити прецизнијом, променити клинички приступ, терапију и ток лечења. Њихов задатак је да:

- пружају прецизне податке,

- да су осетљиви и специфичани,

- да су погодни за одређивање,

- да је узимање узорка безбедно

- да пружају информације које се не могу лако добити клиничким прегледом или другим процедурама,

- да потребно време за добијање резултата није предуго тј. да је прикладно за болест коју испитујемо,

- да је цена сразмерно ниска и да је прихватљив однос цена - резултат.

\subsection{3. Значај и одређивање уринарних биомаркера}

Последњих година развој био-технологије омогућио је значајан напредак у истраживањима на пољу уринарних биомаркера. Сматра се да они имају велику улогу у дијагностици и праћењу тока бубрежних болести. Истраживања на том пољу започета су још у 20. веку, а настављена у 21. веку и базирана су на познавању патофизиолошких механизама. Циљ ових истраживања је откривање протеинских деривата - пептида који би омогућили дијагностику бубрежних болести (акутних бубрежних лезија, гломерулских болести, канцерских лезија, акутног одбацивања графта, бубрежног оштећења у контрастним нефропатијама, системским болестима и многим другим (65-67) (Слика 10). 
Слика 10 - Неки од уринарних биомаркера у акутном бубрежном оштећењу (67)

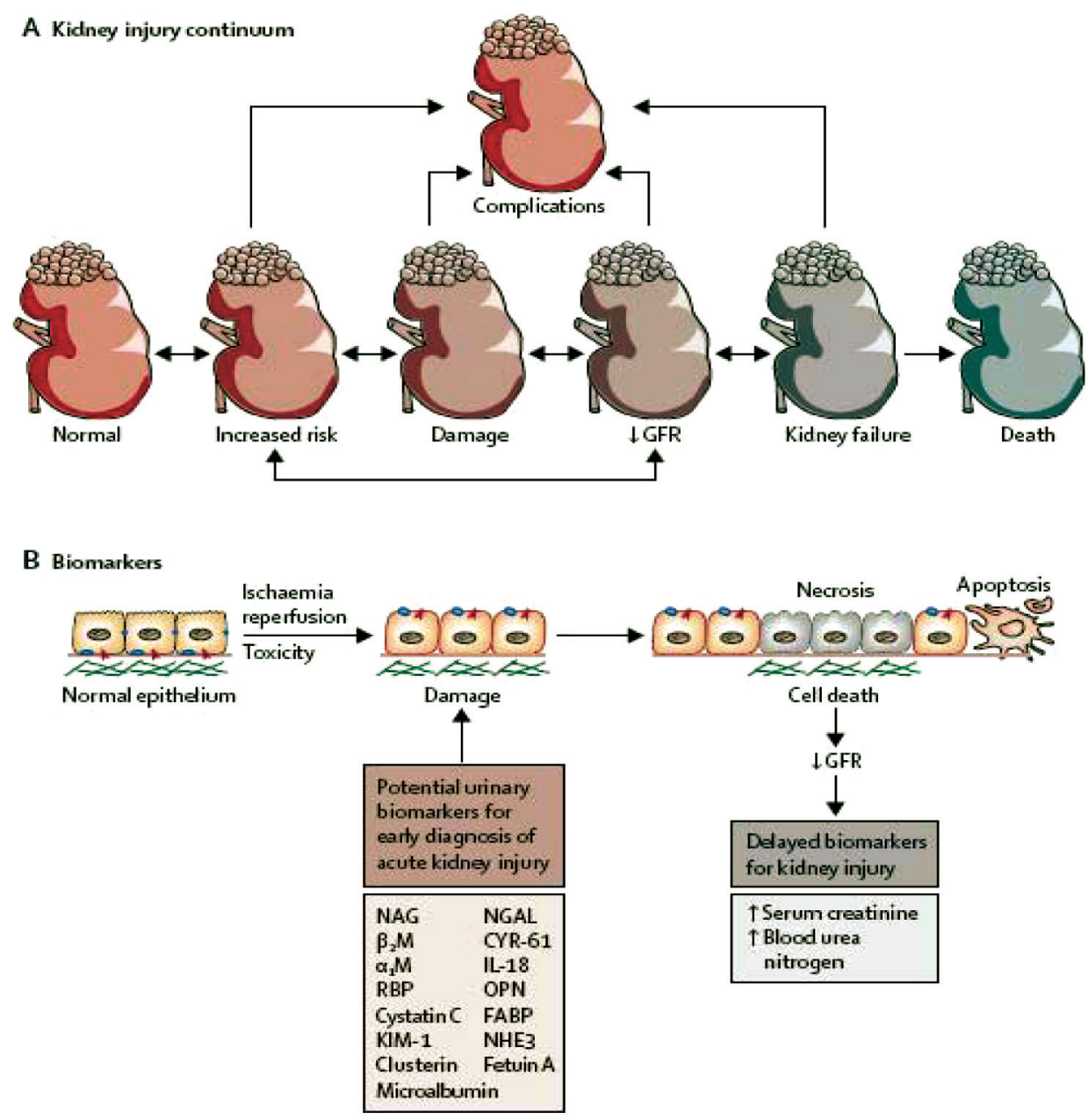

(Lameire, Van Biesen, Vanholder, Lancet 2008; 372; 1863) (67)

Уринарни седимент је обично високе густине, а чине га ћелијски елементи (организвани седимент: епителне ћелије, леукоцити, еритроцити, цилиндри) и различити кристали (неорганизовани седимент: кристали мокраћне киселине, калцијум-оксалата, цистин, амонијум магнезијум фосфати, аморфни урати и други). Повећан број ћелијских елемената, као и кристала је важан показатељ који користимо у свакодневној дијагностици (68).

Међутим, постоје и друге компоненте урина као што су уринарни протеини и пептиди који могу да се изолују у нормалном урину, настају услед апоптозе ћелија у току гломерулске филтрације (епителне ћелије које се нормално обнављају, ексосоме-цитоплазматски фрагменти који су носачи протеина или РНК, затим површински протеини и други). Ти протеини такође могу бити и показатељи бубрежног оштећења. 
Америчка Асоцијација Нефролога (АСН) је у свом извештају још 2005 године јасно нагласила да је развој истраживања биомаркера у раној детекцији акутне бубрежне инсуфицијенције у самом врху приоритетних истраживања $(69,70)$.

У студији Деварајан-а испитивана је сензитивност и специфичност неколико биомаркера у акутном бубрежном оштећењу и то: НГАЛ, Интерлеукин 18 (ИЛ-18), КИМ-1 (kidney injury molecule-1) и Л-ФАБП (liver-type fatty acid binding protein) (71). Иначе, инциденца појаве акутне бубрежне инсуфицијенције (АБИ) у болницама је око 5\%, а у јединицама интензивне неге и до $30 \%$, са тенденцијом ка порасту и посебно са високом стопом смртности $(71,72)$. Уочено је да су много инструктивнији подаци који су добијени истовременим одређивањем више биомаркера. На пример одређивање НГАЛ и ИЛ-18 је посебно значајно у акутној контрастној нефропатији, имајући у виду да је НГАЛ повишен већ на самом почетку појаве лезије бубрега (у првих 2 сата), а ИЛ-18 у првих 10 сати достиже свој максимум. Такође закључено је да одређивање више биомаркера пружа податке значајне и за етиологију, тежину и трајање акутне бубрежне лезије, потребу за методама замене бубрежне функције (дијализа), дужину болничког лечења, морталитет У овој групи биомаркера који су испитивани највећу сензитивност за настанак акутне бубрежне лезије имао је НГАЛ који је такође био и најранији биомаркер у урину (Слика 11) (71).

Слика 11 - Уринарни биомаркери значајни у раној детекцији АБИ (71)

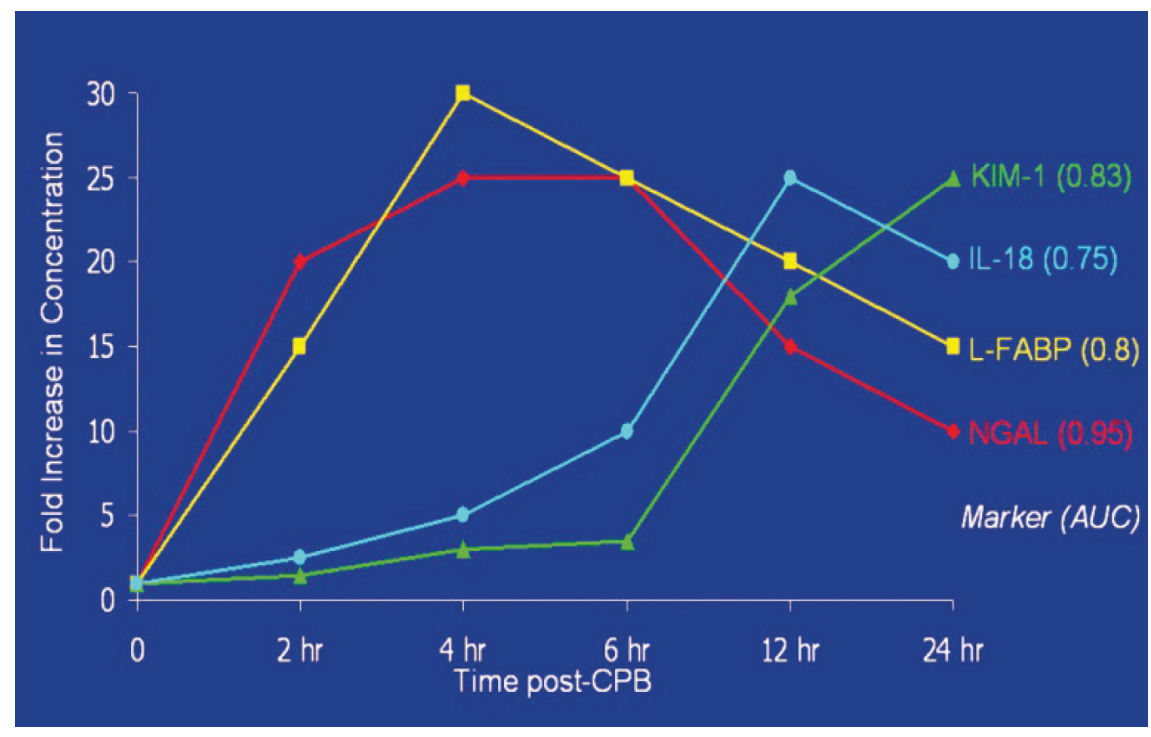

(Devarajan P. Emerging biomarkers of acute kidney injury. Contrib Nephrol 2007; 156: 203-12) (71) 
Уринарни биомаркери су углавном веома мали фрагменти мембрана који се ослобађају у урин и припадају или цитопазматским фрагментима или су последица апоптозе ћелија. Они се обично изолују центрифугирањем умереном брзином. У урину постоје и још ситнији партикли који се називају ексосоме (exosomes) које настају из епителних ћелија, из подоцита или тубулских ћелија проксималних и дисталних тубула. Ексосоме имају величину до 80нм, чине их цитоплазматски партикли са мембраном или пептиди епителних ћелија бубрега, а изолују се такође ултрафилтрацијом или центрифугирањем. Оне су носачи РНК што им даје посебан значај јер могу да укажу на генетске мутације (Слика 12). Захваљујући открићу ексосома и даљим спектрометријским испитивањима, запажени су и други биомаркери у урину $(66,69-71,73)$.

Слика 12 - Механизам формирања уринарних ексосома и њихова екскреција урином (66)

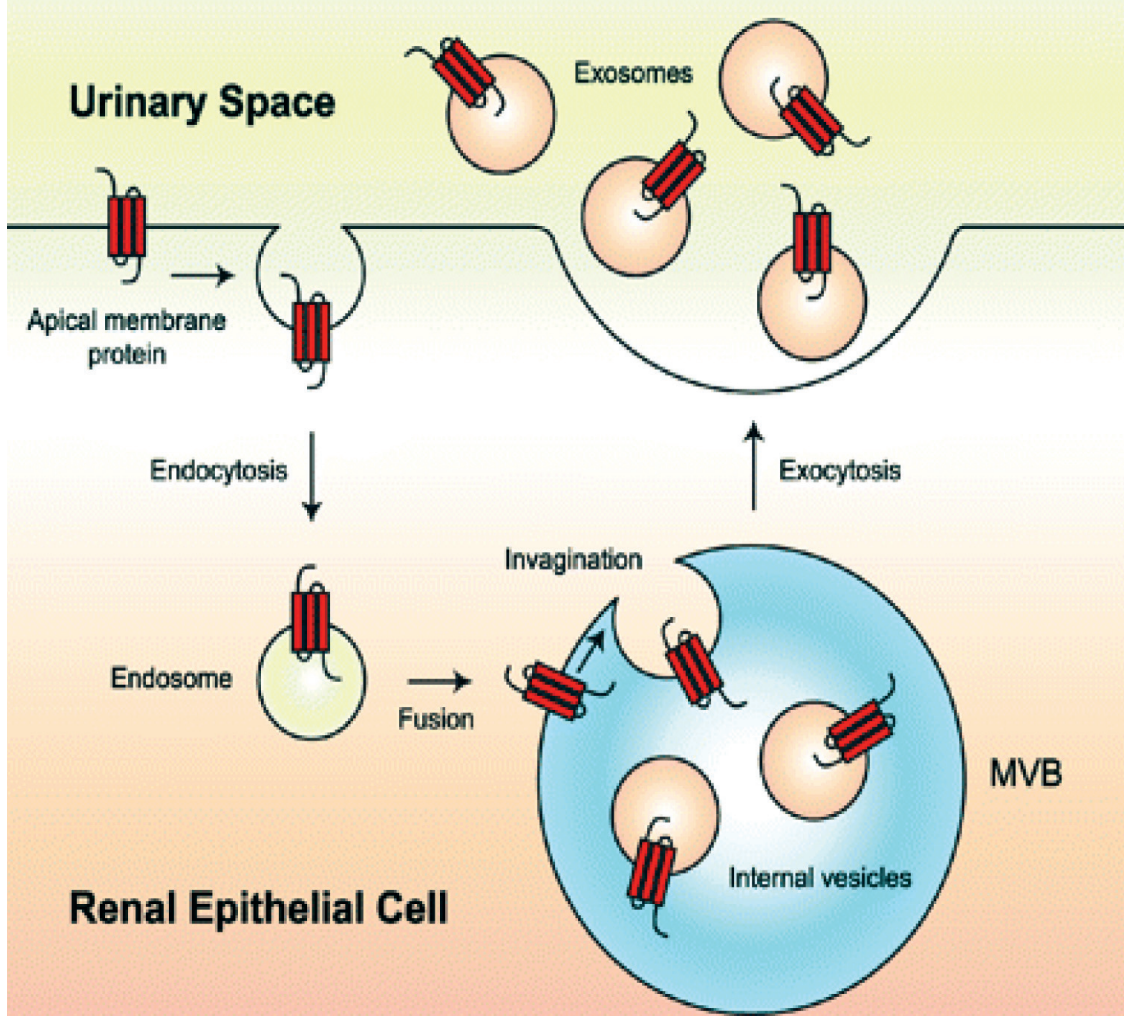

Pisitkun T, Johnstone R, Knepper MA. Discovery of Urinary Biomarkers.

Mol Cellu Proteomics 2006; 5 (10):1760-71. (66)

Данас се користе методе спектрометрије (mass-spectometry) које откривају промене у количини излучених специфичних пептида и протеина, што је значајно у раној дијагнози болести, у процени могућег одговора на лечење или за промену терапијског модалитета и на тај начин и у прогнози болести. 
Уринарни биомаркери су значајни не само у обољењима бубрега, већ и у другим системским болестима у којима се у гломерулима филтрирају и круже мали протеини и пептиди потенцијални индикатори болести. Идентификација биомаркера се обавља углавном на следеће начине:

- дводимензионалном електрофорезом спектрометријском методом (mass spectometry)

- и /или имунохемијском идентификацијомпротеина-спектрометријски (mass spectometry) СЕЛДИ-ТОФ-МС и капиларна електрофореза - МС (74-79). Данас се ради и ЛЦ-МС/МЦ метода за квантификацију (79).

\section{4. ЛИПОКАЛИН УДРУЖЕН СА НЕУТРОФИЛНОМ ГЕЛАТИНАЗОМ (НГАЛ)}

\subsection{1. Структура НГАЛ}

Липокалин удружен са неутрофилном гелатиназом (НГАЛ) или - Neutrophil gelatinase - associated lipocalin - познат је као липокалин 2 или сидерокалин, а представља протеин тежине $25 \mathrm{kDa}$, који је ковалентно везан за гелатиназу из неутрофила, а луче га специфичне грануле неутрофила након активације ћелија.

Породицу липокалина чини велики број чланова (више од 25) и свако од њих има способност да везује липофилне супстанце у језгро, односно да се удружују са другим протеинима обично као мономери и хомодимери (80-84).

У хемијском смислу НГАЛ представља гликопротеин везан за металопротеиназу 9 (ММП-9) у хуманим неутрофилима $(85,86)$ (Слика 13 и Слика 14).

Слика 13 - Кристалана структура хуманог НГАЛ у којој је липокалин удружен са гелатиназом- мономер (85)

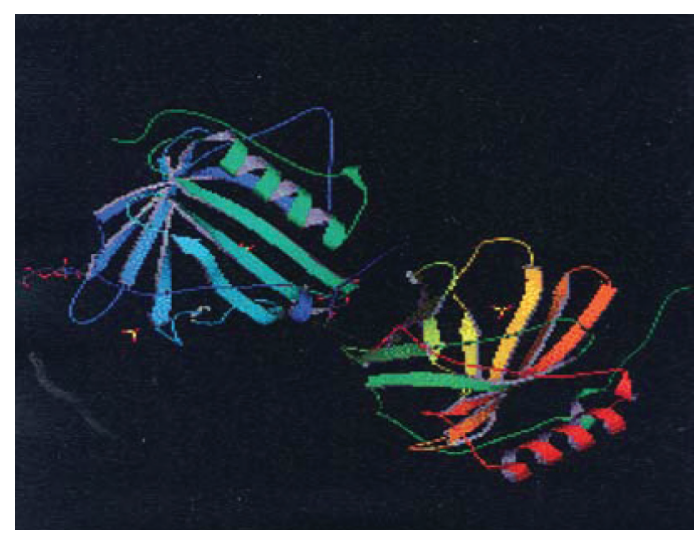


Слика 14 - Молекулска структура НГАЛ (85)

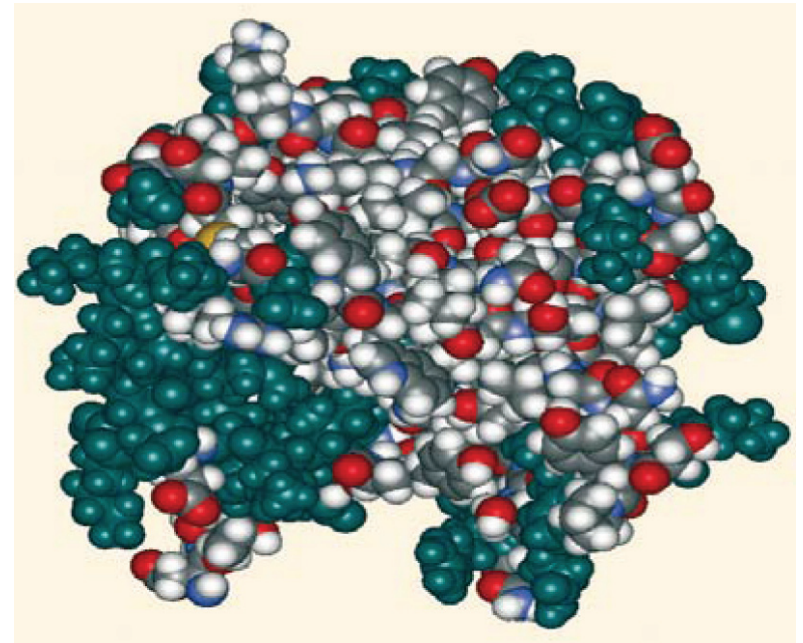

НГАЛ је сачињен од великог броја малих секреторних протеина тродимензионалне структуре који су и ефикасни носачи различитих супстанци (ретиноида, арахидонске киселине, простагландина, масних киселина, стероида, гвожђа, феромона и других) $(64,79,81)$. Централни део НГАЛ су аминокиселине, а поред ММП је и ентерохолин - сидерофоре са великим афинитетом за везивање гвожђа (80-86). То је посебно важно због познате чињенице да бактерије продукују сидерофоре (веома потентне носаче гвожђа) и у екстрацелуларном простору се везују за гвожђе. Ова чињеница је у експерименталним условима на мишевима указала да спој сидерофора и гвожђа јесте сензитиван показатељ грам-негативне бактеријске инфекције што је значајно посебно у развоју сепсе (87-89).

\subsection{2. Значај одрђивања НГАЛ}

НГАЛ се понекад у веома ниској концентрацији запажа и код здравих људи. Повишени нивои НГАЛ-а су повезаини са стањима инфламације у оквиру акутног перитонитиса, апендицитиса, дивертикулитиса, цистичне фиброзе, али и многих других обољења (79-82). На експерименталном моделу акутног бубрежног оштећења, закључено је да је НГАЛ један од најпотентнијих регулаторних протеина, као и у транспорту гвожђа, апоптози ћелија, бактериостази, диференцијацији ткива $(66,89)$. Такође је запажено, да је НГАЛ у циркулацији вишеструко повишен у току кардиоторакалних операција, због инфламаторног механизма активације леукоцита који је покренут применом екстракорпоралне циркулације (90). Активацијом неутрофила долази до ослобађања 
протеолитичких и лизозомских ензима који доприносе повећању васкуларне пропустљивости, па је НГАЛ схваћен као инфламаторни протеин (90).

Након исхемијско-реперфузијског оштећња, код деловања нефротоксичних супстанци и у сепси, бубрег реагује већ у првих 30 минута излучујући преко епителних ћелија тубула велике количине НГАЛ-а у урин (91). Због ове чињенице НГАЛ је назван и бубрежним „тропонином” као алузија на улогу тропонина као дијагностичког и прогностичког параметра у акутном коронарном синдрому (92-94).

Ранијих година у студијама прво у дечијој популацији, а касније и код одраслих особа запажено је да је развоју акутне бубрежне инсуфицијенције (АБИ) у јединицама интензивне неге претходило вишеструко повећање концентације уринарног НГАЛ-а у односу на контролну групу $(91,92)$.

Мерењем нивоа НГАЛ-а у урину и у плазми, након кардиохируршких интервенција доказано је да је он рани показатељ бубрежног оштећења (71, $92,93)$. При томе сматра се да је уринарни НГАЛ (у/НГАЛ) много сензитивнији показатељ акутног бубрежног оштећења од серумског НГАЛ-а (с/НГАЛ), јер се појављује раније. У поређењу са серумским креатинином 1-3 дана пре пораста креатинина указује на акутну лезију бубрега $(93,94)$.

АБИ се данас у лабораторијским анализама презентује порастом креатинина, међутим познато је да је креатинин показатељ који се јавља доста касно и зависи од многих елемената (година, пола, мишићне масе, лекова, уноса течности, физичког напрезања и других) па у акутној фази, серумски креатинин и промена гломерулске филтрације нису довољно сензитивни показатељи (92).

Међутим АБИ настала после кардио-пулмоналних операција представља животно угрожавајућу компликацију, а њено благовремено откривање базирано је углавном на анализи серумског креатинина за који се зна да се мења тек када бубрежна функција опадне за 50\%. НГАЛ мерен у серуму и у урину је значајно повишен у тим фазама што га чини идеалним маркером за рану детекцију бубрежног оштећења $(95,96)$.

То је показала и проспективна студија код педијатријских болесника након кардио-торакалних операција указавши да је дијагноза АБИ (која је описана као пораст серумског креатинина за 50\%) постављана 1-3 дана након интервенције. Међутим мерењем НГАЛ у плазми и у урину запажен је пораст нивоа већ 2-6 часова након операције (89). Ова истраживања су потврђена и у одраслој популацији. 
АБИ након кардиохируршких интервенција корелира са порастом уринарног НГАЛ већ после 3-5 часова након интервенције (93). Зато многи аутори сматрају да је мерење НГАЛ-а у јединицама интензивне неге неопходан елемент за успешно лечење ових болесника јер указује на тежину акутне бубрежне лезије и на тај начин омогућава планирање броја дијализних процедура, а тиме утиче и на дужину хоспитализације и на морталитет.

Shemin D и сарадници, закључују да би НГАЛ у урину због вишеструког значаја требало да буде одређиван у рутинским лабораторијским анализама у јединицама интензивне неге, педијатрији и у хирургији (97).

Parikh и сарадници, су у мултицентричној проспективној студији која је обухватила 1219 адултних болесника након кардиохируршких операција у раном постоперативном периоду мерили ниво биомаркера: НГАЛ у серуму, НГАЛ у урину и ИЛ 18, са идејом да се рано идентификују болесници са потенцијалним развојем АБИ (98). Код болесника који су развили АБИ максимална вредност ових биомаркера запажена је у првих 6 сати после операције. Наравно то су били болесници код којих је хоспитализација дуже трајала као и време проведено у јединици интензивне неге, код њих су чешће спровођене дијализе и ризик од леталног исхода је био већи (98).

Мерења уринарне екскреције биомаркера Цистатина Ц, НГАЛ-а, ИЛ8, КИМ-1, алкалне фосфатазе и гама-глутамил-транспептидазе код болесника са развојем АБИ у јединицама интензивне неге, од стране Ralib и сарадника, указала су на њихова значајна повећања (99). Они су као и дрги аутори раније, потврдили значај одређивања НГАЛ-а у урину (99). Од 6 испитиваних биомаркера само је 24 часовно излучивање НГАЛ (више од $184 \mathrm{ng} / \mathrm{ml}$ ) означавало групу болесника која је имала 2,1 пута већу учесталост смртности у току следећих 365 дана (99).

Пораст нивоа НГАЛ у серуму запажен у току и након церебро-васкуларних инсулта (ЦВИ), што је значајан податак имајући у виду да је ЦВИ трећи по реду узрок морталитета у развијеним земљама (100). У четворогодишњој студији на болесницима након акутне церебралне исхемије праћени су маркери активираних леукоцита, међу којима је био и НГАЛ, а у вези са инциденцом кардиоваскуларне смртности. Показано је да активирани леукоцити представљају предикторе кардиоваскуларног морталитета. Ниво НГАЛ и осталих праћених параметара (неутрофил протеиназе 4 - NP4 и тумор некрозис фактора рецептора протеина 1 - sTNFR-1) значајно је био повишен $(\mathrm{p}<0,005)$ у групи болесника са високом смртношћу (81). У последње време истраживања 
су усмерена и ка утврђивању улоге повишеног нивоа НГАЛ-а у срчаној слабости, коронарно-оклузивној болести срца и у атеросклерози (101).

НГАЛ је заступљен у ткивима и системима који су посебно изложени спољашњој средини као што су респираторни, гастроинтестинални и уринарни, па је и важан елемент одбране од егзогених бактеријских инфекција (102). Посебно је запажен пораст уринарног НГАЛ у инфективним стањима као што су инфекције уринарног тракта (102). Постоји више студија у којима је запажено да НГАЛ везан у неутрофилима односно у епителним ћелијама проксималних тубула представља маркер који је вишеструко повишен у инфекцијама уринарног тракта $(103,104)$.

Yilmaz и сарадиници су одређивали уринарни НГАЛ код деце у инфекцијама уринарног тракта и запазили су да је његова сензитивност 97\%, а специфичност 76\% (AUC: 0.979) (103). Они су закључили да се НГАЛ у урину код педијатријских болесника може користити за рано откривање инфекција уринарног тракта, али у одсуству акутне бубрежне лезије и хроничне бубрежне болести. Такође, указали су и да је у уринарним инфекцијама оптимални „сutoff“ уринарног НГАЛ-а, нижи у поређењу са нивоом који НГАЛ достиже у АБИ (103).

Мерењем нивоа комплекса НГАЛ/ММП-9 у урину такође у групи педијатријских болесника са уринарном инфекцијом Hatipoglu S и сарадници су запазили корелацију са позитивним нитритима у урину и леукоцитуријом, али не и са позитивним налазом ЦРП у серуму и леукоцитозом (104). Средња вредност нивоа уринарног комплекса НГАЛ/ММП-9 у групи болесника са уринарном инфекцијом била је сигнификантно виша ( $<$ < 0.0001) у поређењу са групом код које је урин био контаминиран. Није запажена статистички сигнификантна разлика у нивоу овог комплекса између контролне групе без уринарне инфекције и групе код које је урин био контаминиран (104). Њихов закључак је био да се одређивањем комплекса НГАЛ/ММП-9 у урину код уринарних инфекција може пратити одговор на лечење, али је запажено и да је значајан у диференцијалној дијагнози између контаминације урина и уринарне инфекције (104).

У малигним и у запаљенским обољењима црева оштећења мукозе као функционе баријере колона резултирају абсорбовањем бактеријских продукта у лумен црева, што додатно повећава инфламаторни одговор. Веома повишен ниво НГАЛ запажен је у епителним ћелијама колона и сматра се да је последица везивања са бактеријским пептидима, а посебно у стањима дивертику- 
литиса, апендицитиса као и осталих запаљењских обољења колона $(105,106)$. Повишен ниво НГАЛ запажен је и у премалигним и малигним лезијама црева. У аденокарциному колона је посебно повећана експресија НГАЛ у мукози и у суперфицијуму па се закључује да је синтеза НГАЛ у епителним ћелијама инфламаторних и неопластичних колоректалних болести значајно повишена $(105,106)$.

Потенцијална корист од одређивања у/НГАЛ-а код оболелих од карцинома, запажена је у праћењу одговора на терапију, али и у праћењу акутног бубрежног оштећења које може бити компликација болести или услед нефротоксичног ефекта антиканцерске терапије. Тако се запажа пораст у/НГАЛ-а у примарном карциному дојке (дукталном), али и при развоју цисплатинске нефротоксичности која је у 1/3 пацијената узрок акутне бубрежне инсуфицијенције $(107,108)$. Тај нефротоксични ефекат је дозно - завистан, а имајући у виду да је са већом дозом цисплатина јачи и антинеопластички ефекат (92). У том погледу највећи број испитивања се односио на цисплатин који је заступљен у око 50\% хемиотерапијских протокола, а јачина ефекта је дозно зависна (107).

На експерименталном (анималном) моделу цисплатинске нефротоксичности већ 3 сата по апликацији цисплатина детектује се пораст НГАЛ-а у урину $(108,109)$. Пораст креатинина у серуму запажа се тек након 96 часова по апликацији лека $(108,109)$. Тако је закључено да је у/НГАЛ потенцијални неинвазивни маркер за рану детекцију акутне бубрежне лезије изазване цисплатином, па би његово одређивање могло да омогући индивидуализацију дозе лека или увођење рено-протективних лекова $(108,109)$. Важно је такође да акутна лезија бубрега у великој мери погоршава опште стање малигних болесника и доводи до додатних компликација (исхемијских, кардиолошких, инфективних итд.) (71, 107-112).

Одређивање нивоа НГАЛ- а као параметра акутног бубрежног оштећења је значајно и у трансплантацији бубрега. Протоколарне биопсије бубрега учињене 1 сат након постављања васкуларне анастомозе у току трансплантације, указују на значајну корелацију између у/НГАЛ и појаве одложене функције графта $(101,113,114)$. Мерењем у/НГАЛ-а код болесника са трансплантираним бубрегом прати се његов пораст који је последица реперфузијско-исхемијских оштећења и врло рано може указати на одложену функцију графта (111). У проспективној мултицентричној студији код деце и одраслих мерењем нивоа у/НГАЛ-а у узорцима прикупљеним на дан транс- 
плантације идентификовани су пацијенти који су касније развили одложену функцију графта, а која се испољила тек након 2-4 дана (114).

У студији Magnussona и сарадника, поређени су нивои НГАЛ у плазми код трансплантираних болесника, са нивоима НГАЛ-а код болесника са уремијом, као и са групом здравих особа (115). Они су запазили да је ниво НГАЛ у групи болесника пре трансплантације и у групи болесника са уремијом, сигнификантно виши у односу на здраве особе (р < 0,0001) (115). Након трансплантације ниво НГАЛ је корелирао са серумским креатинином и временом трајања терминалне бубрежне слабости ( $<<0,0001)$, а после 3 и 12 месеци од трансплантације ниво НГАЛ је био нижи и у корелацији са хомоцистеином, што је можда одраз атеросклеротске компоненте бубрежне болести (115).

Овај закључак је у складу са студијама које су указале на везу између НГАЛ у плазми, хомоцистеина, ГФР и креатинина у серуму код болесника са атеросклерозом каротидних крвних судова, што потврђује значај одређивања НГАЛ и у кардиоваскуларним болестима (116).

Malyszko и сарадници су пратили ГФР, серумски креатинин, ниво у/ НГАЛ у групи болесника са хроничном бубрежном инсуфицијенцијом (ХБИ) (стадијум 2-4) - не-дијабетичара и поредили са групом трансплантираних болесника (не-дијабетичара) који су били на терапији калцинеуринским инхибиторима, микофенолат мофетилом и кортикостероидима и са трећом групом коју су представљале здраве особе (117). Они су запазили да је ниво у/ НГАЛ и серумског креатинина значајно виши, а ГФР је нижа у групи болесника са ХБИ и код трансплантираних у односу на здраве особе. Такође су запазили да је ниво НГАЛ већи код болесника са ХБИ - стадијум 4, у односу на ХБИ у стадијуму 2 (117). Код болесника са ХБИ, НГАЛ у урину је корелирао са серумским креатинином и ГФР, а код трансплантираних болесника је корелирао значајно још и са концентрацијом циклоспорина у крви и ЦРП-ом. Код здравих особа ниво НГАЛ је корелирао са годинама старости, серумским креатинином и ГФР (117). Они су такође закључили да је ниво у/НГАЛ бољи показатељ циклоспоринске нефротоксичности од серумског креатинина (117).

И други аутори сматрају да је НГАЛ добар биомаркер и хроничног бубрежног обољења имајући у виду да ниво у плазми корелира са гломерулском филтрацијом боље од серумског креатинина (101, 117-120). Код болесника са хроничном бубрежном инсуфицијенцијом насталом услед прогресије гломерулонефритиса, ниво уринарног НГАЛ корелираће са серумским креатинином, ГФР и протеинуријом, а студије са овим болесницома такође указују 
да ниво НГАЛ много боље корелира са смањењем гломерулске филтрације од серумског креатинина (118-120).

Имајући у виду веома значајну улогу тубуларног оштећења у прогресији бубрежне болести ниво НГАЛ је према неким ауторима и маркер за резидуалну бубрежну функцију. Прелиминарна истраживања нивоа у/НГАЛ код болесника са израженом протеинуријом на почетку лечења указују на корелацију са високим нивоом у/НГАЛ и са погоршањем бубрежне функције у наредних годину дана (121).

Код деце са стероид-зависним нефротским синдромом која су лечена циклоспорином, мерењем НГАЛ у плазми и у урину запажено је, да је пре започињања лечења Циклоспорином (ЦсА) ниво НГАЛ исти као и код контролне групе који су чинили здрави ( $>>0.05)$. Такође запажен је пораст НГАЛ у серуму и у урину у току самог лечења ЦсА ( $<<0.01)$, као и позитивна коорелација између НГАЛ у урину и у серуму са нивом ЦсА у серуму. Аутори сматрају да би будуће студије на већем броју болесника могле да потврде значај одређивања НГАЛ у дијагностици степена тубулоинтерстицијског оштећења насталог у оквиру циклоспоринске нефротоксичности (122).

У експерименталним условима запажено је да ниво НГАЛ означава оштећење мезангијалних ћелија бубрега код мишева који су третирани нефритогеним анти-дс ДНА антителима (123).

НГАЛ у серуму и у урину је биомаркер који је протеклих година испитиван углавном у бубрежном оштећењу које је последица акутних дешавања у оквиру различитих стања (91-117). У тим ситуацијама НГАЛ се показао као веома сензитиван, рани показатељ бубрежне лезије, а као такав значајан је за избор могалитета лечења, дозе лекова, дужину терапије, даљи ток и прогнозу.

Међутим мали је број студија у којима је значај НГАЛ-а испитиван у хроничним гломерулским обољењима (118-122). Последњих година објављене су студије у којима се указује на значај одређивања НГАЛ у примарним и секундарним гломерулонефритисима, односно запажено је да се ниво у/НГАЛ повећава у стањима активне болести.

Ретке су и студије у којима је испитиван НГАЛ у развоју бубрежне лезије код СЛЕ. ЛН као једна од најозбиљнијих манифестација СЛЕ, погошава стање болесника и може бити узрок озбиљних и трајних последица, као и смртног исхода. Лечење ЛН је тешко, дуготрајно, а исход може бити неизвес- 
тан и поред примене најсавременијих лекова и процедура у лечењу. Посебну потешкоћу у лечењу ЛН представљају и могући релапси и егзацербације болести. Идентификација биомаркера који би био показатељ погоршања болести, а уједно би његово одређивање било једноставно у свакодневној пракси већ дуго представља изазов за истраживаче. Рано откривање активне болести смањило би дугорочни морбидитет и морталитет и имало би велики медицински и социо-економски значај.

Последњих година објављене су студије углавном код педијатријсих болесника и у њима први резултати везани за значај одређивања НГАЛ-а у ЛН $(123,125)$.

Студије у којима је одређиван НГАЛ у адултној групи болесника са СЛЕ и ЛН су још ређе, али и поред њихових недостатака везаних за методологију (број болесника, недостатак биопсије бубрега и пато-хистолошк верификације класе ЛН, време праћења итд.), претпостављено је да би овај биомаркер код адултних болесника са ЛН био такође веома значајан. Уринарни НГАЛ би могао бити потенцијални показатељ погоршања односно активности лупус нефритиса, а његово одређивање би омогућило рану детекцију и одредио степен бубрежног оштећења. Сматра се да је сензитивнији показатељ активности ЛН у поређењу са титром анти дс-ДНК антитела (85).

Досадашње студије у педијатрији су указале да је ниво урунарног НГАЛ-а веома добар параметар за стабилну ремисију лупус нефритиса $(124,125)$.

Све су ово новија сазнања која би морала бити поткрепљена студијама код одраслих болесника са лупус нефритисом код којих би била искључена потенцијална бубрежна слабост и њен утицај на ниво уринарног НГАЛ и рану детекцију активности Лн. 
2. ЦИЉ ИСТРАЖИВАЊА 


\section{1 ЦИЉЕВИ И ХИПОТЕЗЕ ИСТРАЖИВАЊА}

Циљеви истраживања:

1. Одредити иницијалну концентрацију у/НГАЛ код болесника са активним лупус нефритисом и након 2 и 4 месеца по започињању лечења

2. Одредити иницијалну концентрацију у/НГАЛ код болесника са лупус нефритисом који је у ремисији и пратити их на контролама након 2 и 4 месеца

3. Упоредити параметре активности болести и концентрацију у/НГАЛ код болесника са активном болешћу (испитивана група) и код болесника са лупус нефритисом у ремисији (контролна група)

4.Упоредити параметре активности болести и погоршања бубрежне функције са концентрацијама у/НГАЛ код болесника у испитиваној групи пре и након 2 и 4 месеца лечења.

Хипотезе истраживања:

- Повећана концентрација НГАЛ у урину код болесника са лупус нефритисом је рани биомаркер за активност болести, односно параметар у праћењу ремисије болести.

- Смањење концентрације НГАЛ у урину код болесника са лупус нефритисом у току лечења је поуздан параметар повољног ефекта примењеног лечења. 
3. МАТЕРИЈАЛ И МЕТОДЕ 


\section{1. Место}

Испитивање је обављено у Војномедицинској Академији (ВМА) - Београд и то у Клиници за нефрологију ВМА, Клиници за реуматологију ВМА, лабораторијско -био-хемијске и имунске анализе учињене су у Инситуту за биохемију BMA и Институту за експерименталну медицину и имунологију BMA, а пато-хистолошке анализе у Институту за патологијуи судску медицину BMA.

Студија је одобрена на седници Етичког одбора, Сектора за Лечење, BMA која је одржана 24.03.2011 год. Све особе су добровољно пристале да учествују у студији и информисане су о природи, трајању и очекиваним резултатима истраживања, а од њих је добијена одговарајућа писана сагласност за учешће у студији. Истаживање је спроведено у складу са принципима Хелсиншке декларације добре клиничке праксе.

\section{2. Испитиване групе}

У овој клиничкој, проспективној студији је учествовало 40 болесника са системским еритемским лупусом (СЛЕ), који је потврђен критеријумима Америчке реуматолошке асоцијације (АРА) $(40,41)$ и Лупус нефритисом (ЛН) потврђеним биопсијом бубрега и патохистолошким налазом (према класификацији С30) $(56,57,59)$. Обухваћени су болесници оба пола и различитог старосног доба (старији од 18 година).

Активност бубрежне болести је класификована и према Индексу активности бубрежне болести СЛЕДАИ/р (renal/Systemic Lupus Erythematosus Disease Activity Index - rSLEDAI) (51).

СЛЕДАИ/р се састоји од 4 критеријума који степенују бубрежно оштећење у оквиру СЛЕДАИ 2000 (Systemic Lupus Erythematosus Disease Activity Index-SLEDAI 2000) критеријумима активности за СЛЕ (51).

Овај индекс обухвата следеће параметре:

- хематурију (>5 еритроцита у видном пољу великог увеличања, уз искључење болесника са калкулозом, уринарном инфекцијом или другим узроком хематурије),

- пиурију (>5 леукоцита у видном пољу великог увеличања уз искључење уринарне инфекције), 
- протеинурију (>0.5 г/24ч или однос уринарних протеина/креатинина >0.5),

- цилиндрурију (гранулирани, еритроцитни, хијалини).

Скор реналне активности износио је од 0-16, а укључујући критеријум је био сваки скор активности већи од 0.

Студија је обухватила две групе болесника према јасним критеријимима:

1. Испитивана група: 20 болесника са СЛЕ и ЛН-ом, код којих је болест активна (критеријум за активност болести према стандардним биохемијским анализама: протеинурија $\geq 0,5$ г/24ч; однос уринарних протеина / креатинина $>0,5$; према СЛЕДАИ/р критеријумима; уз снижени комплемент Ц3, Ц4, позитивна анти дс-ДНА антитела и патохистолошки налаз биопсије бубрега).

Болесници су имали клиренс креатинина $\geq 60$ мил/мин./ по Кокрофту

2. Контролна група: 20 болесника са СЛЕ и ЛН-ом, који је у комплетној ремисији (према критеријуму - да је протеинурија $\leq 0,5$ г/24ч, однос уринарних протеина / креатинина <0,5; уз негативна анти - дс ДНА антитела, комплемент Ц3 и Ц4 у референтним границама и са клиренсом креатинина $\geq 60$ мил/мин.

Искључујући критеријуми су били исти и за групу која је испитивана и за контролну групу: болесници млађи од 18 година, болесници са уринарном инфекцијом (позитивна уринокултура), са калкулозом бубрега, са бубрежном инсуфицијенцијом (кл креатинина < 60мил/мин / по Кокрофту).

\section{3. Методологија рада}

Праћен је и поређен однос параметара, између испитиване групе и контролне групе на почетку лечења, као и испитиване и контролне групе током промена активности болести, а које се очекују 2 и 4 месеца по започињању лечења. У моменту одређивања у/НГАЛ независна група колега - нефролога са Клинике је на основу предвиђених параметара, без увида у резултате у/НГАЛ, процењивала активност болести. Такође у очекиваном термину промене активности болести (2-ги и 4-ти месец) праћени су и поређени и други параметри активности болести испитиваних група. Такође обављено је поређење параметара праћења, унутар група и то по визитама на 2 и 4 месеца. 
Параметри који су праћени у свакој визити били су стандардни биохемијски параметри и параметри бубрежне функције: Ц-реактивни протеин (ЦРП), крвна слика (ККС), креатинин, укупни протеини, албумини, холестерол, триглицериди. Такође су праћени и клиренси креатинина по формулама за гломерулска филтрацију (ГФР): ГФР МДРД (Modification of Diet in Renal Disease) и клиренс креатинина / по формули (Cockcroft-Gault) - КККр:

\section{MDRD формула - ГФР МДРД}

ГФР $(\mathrm{ml} / \mathrm{min} / 1.73 \mathrm{~m} 2)=186 \times\{[$ серум креатинин $(\mu \mathrm{mol} / \mathrm{l}) / 88.4]-1.154\}$

$$
\text { × старост (године) - } 0.203 \text { х } 0.742 \text { за жене }
$$

\section{Cockcroft-Gault - Формула (КККр):}

$$
\Gamma Ф \mathrm{P}(\mathrm{ml} / \mathrm{min})=\frac{[140-\text { старост }(\text { године })] \times \text { тел. тежина }(\mathrm{kg}) *(0.85 \text { за жене })}{\text { серум креатинин }(\mu \mathrm{mol} / \mathrm{l}) * 0.8136}
$$

Од имунских анализа праћени су: комплемент Ц3, Ц4, анти нуклеарна антитела (АНА- ХЕП 2 субстрат), анти дс ДНА антитела.

Од анализа у урину: седимент урина, протеинурија по Биурету, уринокултура, однос уринарних протеина и креатинина (Уп/к). Студија је обухватила три визите иницијалну, након 2 и 4 месеца по започињању лечења.

Поред рутинских клиничко-лабораторијских испитивања у време сваке посете, код сваког пацијента је искључиво у узорку првог јутарњег урина који је претходно центрифугиран у центрифуги на 4000 обртаја/мин (због уклањања талога) методом ЦМИА - хемилуминесцент имуноесеј технологијом - која представља имунохемијски тест, одређиван уринарни НГАЛ (комерцијални китови фирме: Abbott Diagnostic на ARCHITECT® i2000 SR аналајзеру). Tо je тест за квантитативно одређивање и заснива се на принципу микрочестица хемилуминисцентног имуноодређивања. Концентрација уринарног НГАЛ-а је изражавана y ng/mil, при чему је горњу референтну границу представљао ниво од 131,7 ng/mil.

\section{4. Статистичка обрада података}

Основна анализа праћених параметара извршена је путем стандардних параметара дескриптивне статистике (средња вредност \pm стандардна 
девијација - SD) или путем регистрације учесталости појаве неких обележја (фреквенција). У зависности од типа поређења (две или више група) и расподеле коришћен је Студентов т-тест алтернативно Ман-Витнијев - У тест (Mann-Whitney - U test) или анализа варијансе у једном правцу (алтернативно Краскал-Валисов тест (Kruskal-Walis test).

Поређење дистрибуција фреквенција различитих група извршено је путем $X^{2}$ теста. Значајност разлика испитиваних обележја прихваћена је на три нивоа значајности $(\mathrm{p}<0,05 ; \mathrm{p}<0,01 ; \mathrm{p}<0,001)$.

Конструисана је РОК крива за у/НГАЛ и одређене граничне вредности на основу израчунатих вредности за специфичност и сензиивност.

Застатистичку анализу коришћен јекомерцијални статистички софтвер: Statistica 8,0, Stat Soft Inc., Tulsa, OK, SAD, 2007.

Снага студије и величина узорка: Да би снага студије била $80 \%$, а вероватноћа грешке првог типа ( $\alpha=0.05)$, а имајући у виду да је разлика између група утврђивана путем $\mathrm{t}$-теста и узимајући у обзир да је очекивана разлика концентрација уринарног НГАЛ између група око $50 \%$ са стандардном девијацијом $\approx \pm 30 \%$, закључено је да је потребан број пацијената 17 (минимално) у свакој групи. 
4. РЕЗУЛТАТИ 


\section{1. Демографски и лабораторијски резултати}

\subsection{1. Демографски подаци испитаника}

Испитивање је обухватило 40 болесника са СЛЕ и ЛН тип IV који су лечени и контролисани у Клиници за нефрологију и Клиници за реуматологију, Војномедицинске Академије у Београду. Испитаници су били подељени у две групе по 20 болесника. Прву групу су чинили болесници са активним ЛН (Група 1/A), а другу групу (Група 2/Р) болесници са ЛН који је у ремисији.

Табела 6 - Демографски подаци испитаника

\begin{tabular}{|c|c|c|c|c|c|}
\hline \multirow{2}{*}{ Параметри } & \multicolumn{4}{|c|}{ Групе $(\mathrm{H}=20)$} & \multirow{2}{*}{$\begin{array}{c}\text { Поређење између } \\
\text { група }\end{array}$} \\
\hline & \multicolumn{2}{|c|}{$1 / \mathrm{A}$} & \multicolumn{2}{|c|}{$2 / P$} & \\
\hline \multirow{2}{*}{ Пол } & женски & мушки & женски & мушки & \multirow{2}{*}{$x^{2}=0,69 ; p=0,40$} \\
\hline & $15(75 \%)$ & $5(25 \%)$ & $18(90 \%)$ & $2(10 \%)$ & \\
\hline \multicolumn{6}{|c|}{$\overline{\mathrm{X}} \pm$ СД } \\
\hline Год. старости & \multicolumn{2}{|c|}{$37,50 \pm 15,74$} & \multicolumn{2}{|c|}{$42,65 \pm 12,44$} & $\mathrm{t}=1,14 ; \mathrm{p}=0,25$ \\
\hline $\begin{array}{l}\text { Тел. тежина } \\
\text { Визита } 0 \\
\text { Визита } 1 \\
\text { Визита } 2\end{array}$ & $\begin{array}{l}68,74 \pm 12, \\
67,46 \pm 13, \\
66,30 \pm 13,\end{array}$ & & \multicolumn{2}{|c|}{$67,27 \pm 9,92$} & $\begin{array}{l}t=0,40 ; p=0,68 \\
t=0,25 ; p=0,79 \\
t=0,13 ; p=0,89\end{array}$ \\
\hline Тип Лн & \multicolumn{2}{|c|}{ IV } & \multicolumn{2}{|c|}{ IV } & \\
\hline Лечење & \multicolumn{4}{|c|}{$\begin{array}{l}\text { Кортикостероиди, Циклофосфамид, } \\
\text { Микофенолат, Азатиоприн/Циклоспорин }\end{array}$} & \\
\hline
\end{tabular}

Увидом у податке може се закључити да не постоји статистички значајна разлика између група у односу на дистрибуцију болесника према полу, годинама и телесној тежини.

\subsection{2. Лабораторијски резултати испитаника}

У следећим табелама приказани су лаб. резултати испитаника по визитама 0-2 (Табеле 7, 8, 9, 10). 
Табела 7 - Лабораторијски параметри по визитама за обе групе - Крвна слика

\begin{tabular}{|c|c|c|c|}
\hline Параметри: ККС & $\begin{array}{c}1 / \mathrm{A} \\
\overline{\mathrm{X}} \pm \text { СД }\end{array}$ & $\begin{array}{c}2 / P \\
\bar{X} \pm \text { СД }\end{array}$ & $\begin{array}{c}\text { Поређење } \\
\text { између група }\end{array}$ \\
\hline $\begin{array}{l}\text { Еритроцити: Ep } 10^{12} / \mathrm{L} \\
\text { Визита } 0 \\
\text { Визита } 1 \\
\text { Визита } 2\end{array}$ & $\begin{array}{l}4,02 \pm 0,68 \\
4,25 \pm 0,48 \\
4,25 \pm 0,46\end{array}$ & $\begin{array}{l}4,34 \pm 0,47 \\
4,45 \pm 0,44 \\
4,57 \pm 0,46\end{array}$ & $\begin{array}{l}p=0,099 \\
p=0,189 \\
\mathbf{p}=\mathbf{0 , 0 2 4} *\end{array}$ \\
\hline $\begin{array}{l}\text { Хемоглобин: Хб (g/L) } \\
\text { Визита } 0 \\
\text { Визита } 1 \\
\text { Визита } 2\end{array}$ & $\begin{array}{l}111,16 \pm 15,10 \\
120,30 \pm 13,03 \\
121,45 \pm 12,25\end{array}$ & $\begin{array}{l}124,25 \pm 12,83 \\
127,95 \pm 12,12 \\
139,60 \pm 42,38\end{array}$ & $\begin{array}{l}\mathbf{p}=\mathbf{0 , 0 0 5} * * \\
p=0,062 \\
p=0,071\end{array}$ \\
\hline $\begin{array}{l}\text { Леукоцити: Ле } 10^{9} / \mathrm{L} \\
\text { Визита } 0 \\
\text { Визита } 1 \\
\text { Визита } 2\end{array}$ & $\begin{array}{l}6,00 \pm 2,02 \\
7,14 \pm 2,49 \\
6,50 \pm 2,08\end{array}$ & $\begin{array}{l}7,02 \pm 3,58 \\
7,31 \pm 2,69 \\
7,41 \pm 2,82\end{array}$ & $\begin{array}{l}p=0,274 \\
p=0,832 \\
p=0,256\end{array}$ \\
\hline $\begin{array}{l}\text { Тромбоцити: Tp } \times 10^{9} / \mathrm{L} \\
\text { Визита } 0 \\
\text { Визита } 1 \\
\text { Визита } 2\end{array}$ & $\begin{array}{l}206,55 \pm 55,01 \\
225,10 \pm 42,57 \\
232,60 \pm 42,04\end{array}$ & $\begin{array}{c}248,05 \pm 106,64 \\
251,00 \pm 101,49 \\
264,05 \pm 92,09\end{array}$ & $\begin{array}{l}p=0,130 \\
p=0,360 \\
p=0,231\end{array}$ \\
\hline
\end{tabular}

${ }^{*} \mathrm{p}<0,05 ;{ }^{* *} \mathrm{p}<0,01 ; * * * \mathrm{p}<0,001$

Поређењем средњних вредности параметара крвне слике по визитама запажа се да скоро да нема статистички значајне разлике међу групама. Разлика је значајна $\left(\mathrm{p}=0,005^{* *}\right)$ у поређењу нивоа хемоглобина у нултој визити између група, као и еритроцита у другој визити $\left(\mathrm{p}=0,024^{*}\right)$, уз напомену да је ниво еритроцита у референтним границама у обе групе.

Табела 8 - Параметри бубрежне функције по визитама за обе групе

\begin{tabular}{|c|c|c|c|}
\hline $\begin{array}{c}\text { Параметри: } \\
\text { бубрежне функције }\end{array}$ & $\begin{array}{c}\mathbf{1 / A} \\
\overline{\mathrm{X}} \pm \text { СД }\end{array}$ & $\begin{array}{c}\mathbf{2 / P} \\
\overline{\mathrm{X}} \pm \text { СД }\end{array}$ & $\begin{array}{c}\text { Поређење } \\
\text { између група }\end{array}$ \\
\hline $\begin{array}{l}\text { Креатинин Кр (umol/l) } \\
\text { Визита } 0 \\
\text { Визита } 1 \\
\text { Визита } 2\end{array}$ & $\begin{array}{l}87,65 \pm 33,09 \\
82,10 \pm 27,86 \\
78,00 \pm 22,59\end{array}$ & $\begin{array}{l}79,15 \pm 19,93 \\
75,45 \pm 16,03 \\
72,15 \pm 16,16\end{array}$ & $\begin{array}{l}p=0,331 \\
p=0,360 \\
p=0,352\end{array}$ \\
\hline $\begin{array}{l}\text { Клиренс креатинина } \\
\text { ГФР / МДРД (ml/min) } \\
\text { Визита } 0 \\
\text { Визита } 1 \\
\text { Визита } 2\end{array}$ & $\begin{array}{l}86,52 \pm 29,92 \\
90,55 \pm 29,73 \\
94,65 \pm 25,04\end{array}$ & $\begin{array}{l}88,61 \pm 29,69 \\
88,74 \pm 25,88 \\
94,63 \pm 29,1\end{array}$ & $\begin{array}{l}p=0,825 \\
p=0,842 \\
p=0,997\end{array}$ \\
\hline $\begin{array}{l}\text { Кл. креатинина } \\
\text { Кокрофт/КККр }(\mathrm{ml} / \mathrm{min}) \\
\text { Визита } 0 \\
\text { Визита } 1 \\
\text { Визита } 2\end{array}$ & $\begin{array}{l}106,74 \pm 29,23 \\
111,74 \pm 32,97 \\
113,64 \pm 26,30\end{array}$ & $\begin{array}{l}103,33 \pm 23,39 \\
110,61 \pm 23,34 \\
111,20 \pm 24,66\end{array}$ & $\begin{array}{l}p=0,406 \\
p=0,125 \\
p=0,302\end{array}$ \\
\hline
\end{tabular}

$\left.{ }^{*} \mathrm{p}<0,05\right) ;{ }^{* *} \mathrm{p}<0,01 ;{ }^{* * *} \mathrm{p}<0,001$ 
Није утврђена статистички значајна разлика у параметрима бубрежне функције у серуму (креатинин, клиренс креатинина - по ГФР МДРД, клиренс креатинина по Кокрофту), што је сасвим разумљиво имајући у виду критеријуме за укључење болесника у студију. Недостатак ове значајности подвачи значај у/НГАЛ-а као параметра у ЛН јер искључује могућност да је он параметар акутизације бубрежне слабости.

Табела 9 - Биохемијски и имунски параметри обе групе у визитама

\begin{tabular}{|c|c|c|c|}
\hline $\begin{array}{c}\text { Параметри: } \\
\text { Биохемијске и имунске анализе }\end{array}$ & $\begin{array}{c}\mathbf{1 / A} \\
\overline{\mathrm{X}} \pm \text { СД }\end{array}$ & $\begin{array}{c}\mathbf{2 / P} \\
\overline{\mathrm{X}} \pm \text { СД }\end{array}$ & $\begin{array}{c}\text { Поређење } \\
\text { између група }\end{array}$ \\
\hline Ц-реактивни протеин: ЦРП(mg/L) & & & \\
\hline Визита 0 & $5,66 \pm 6,17$ & $3,75 \pm 1,48$ & $p=0,357$ \\
\hline Визита 1 & $4,42 \pm 3,45$ & $3,16 \pm 0,61$ & $p=0,043^{*}$ \\
\hline Визита 2 & $3,47 \pm 0,61$ & $3,48 \pm 2,29$ & $p=0,030 *$ \\
\hline Укупни протеини: УП (g/l) & & & \\
\hline Визита 0 & $59,65 \pm 9,12$ & $67,15 \pm 9,25$ & $\mathbf{p}=0,013^{* *}$ \\
\hline Визита 1 & $61,80 \pm 5,86$ & $67,90 \pm 7,46$ & $\mathrm{p}=0,006^{* *}$ \\
\hline Визита 2 & $62,85 \pm 5,20$ & $68,75 \pm 8,46$ & $p=0,231$ \\
\hline Албумини: Алб (g/l) & & & \\
\hline Визита 0 & $33,35 \pm 7,88$ & $39,05 \pm 4,45$ & $\mathbf{p}=0,007^{* *}$ \\
\hline Визита 1 & $37,20 \pm 4,25$ & $40,20 \pm 4,67$ & $p=0,040^{*}$ \\
\hline Визита 2 & $38,85 \pm 4,36$ & $40,50 \pm 4,90$ & $p=0,268$ \\
\hline Холестерол: Хол (mmol/l) & & & \\
\hline Визита 0 & $5,22 \pm 1,36$ & $5,35 \pm 0,81$ & $p=0,714$ \\
\hline Визита 1 & $5,30 \pm 0,95$ & $5,42 \pm 0,95$ & $p=0,695$ \\
\hline Визита 2 & $5,04 \pm 0,81$ & $5,31 \pm 1,26$ & $\mathrm{p}=0,427$ \\
\hline Триглицериди: Триг (mmol/l) & & & \\
\hline Визита 0 & $1,53 \pm 0,65$ & $1,54 \pm 0,34$ & $p=0,961$ \\
\hline Визита 1 & $1,55 \pm 0,71$ & $1,50 \pm 0,28$ & $p=0,764$ \\
\hline Визита 2 & $1,55 \pm 0,78$ & $1,44 \pm 0,43$ & $p=0,599$ \\
\hline Компемент: Ц3 (g/l) & & & \\
\hline Визита 0 & $0,65 \pm 0,16$ & $0,83 \pm 0,11$ & $\mathbf{p}=0.000^{* * *}$ \\
\hline Визита 1 & $0,75 \pm 0,11$ & $0,82 \pm 0,10$ & $\mathrm{p}=0,077$ \\
\hline Визита 2 & $0,79 \pm 0,09$ & $0,86 \pm 0,12$ & $p=0,062$ \\
\hline Комплемент: Ц4 (g/l) & & & \\
\hline Визита 0 & $0,09 \pm 0,11$ & $0,14 \pm 0,03$ & $\mathbf{p}=0,000^{* * *}$ \\
\hline Визита 1 & $0,11 \pm 0,03$ & $0,14 \pm 0,04$ & $\mathrm{p}=0,06$ \\
\hline Визита 2 & $0,18 \pm 0,20$ & $0,15 \pm 0,03$ & $p=0,156$ \\
\hline Анти дс ДНА Антитела (IU/ml) & & & \\
\hline Визита 0 & $105,45 \pm 78,03$ & $12,07 \pm 11,71$ & $\mathrm{p}=0,000^{* * *}$ \\
\hline Визита 1 & $90,05 \pm 91,33$ & $12,00 \pm 14,43$ & $\mathbf{p}=0,000^{* * *}$ \\
\hline Визита 2 & $67,90 \pm 80,37$ & $11,82 \pm 31,26$ & $\mathbf{p}=0,000^{* *}$ \\
\hline
\end{tabular}

${ }^{*} \mathrm{p}<0,05 ;{ }^{* *} \mathrm{p}<0,01 ;{ }^{* * *} \mathrm{p}<0,001$ 
Поредећи средње вредности лабораторијских (биохемијских и имунских) анализа, између група, статистичка значајност је уочена за укупне протеине и албумине у иницијалној (нултој) визити и у првој визити, већ у другој визити та разлика између група је несигнификантна. Комплемент Ц3 и Ц4 је статистички значајно био различит само у поређењу група у нултој визити што је одговарало разлици која је постојала пре започињања лечења, већ у визитама 1 и 2 та разлика је статистички незначајна. Анти дс-ДНА антитела су значајно била различита између група у све три визите.

Табела 10 - Лабораторијски параметри из урина за обе групе у све три визите

\begin{tabular}{|c|c|c|c|}
\hline $\begin{array}{c}\text { Лабораторијски } \\
\text { параметри / урин }\end{array}$ & $\begin{array}{c}\text { 1/A } \\
\overline{\mathrm{X}} \pm \text { СД }\end{array}$ & $\begin{array}{c}\mathbf{2 / P} \\
\overline{\mathrm{X}} \pm \text { СД }\end{array}$ & $\begin{array}{c}\text { Поређење } \\
\text { између група }\end{array}$ \\
\hline \multicolumn{4}{|l|}{ СЛЕДАИ / p } \\
\hline Визита 0 & $5,20 \pm 2,66$ & $0,00 \pm 0,00$ & $\mathbf{p}=0,000 * * *$ \\
\hline Визита 1 & $2,75 \pm 1,80$ & $0,00 \pm 0,00$ & $\mathbf{p}=\mathbf{0 , 0 0 0} * * *$ \\
\hline Визита 2 & $1,60 \pm 1,75$ & $0,00 \pm 0,00$ & $\mathbf{p}=\mathbf{0 , 0 0 0} * * *$ \\
\hline \multicolumn{4}{|l|}{ Протеинурија (g/24h) } \\
\hline Визита 0 & $4,12 \pm 4,08$ & $0,39 \pm 0,35$ & $\mathbf{p}=0,000 * * *$ \\
\hline Визита 1 & $2,00 \pm 1,32$ & $0,33 \pm 0,27$ & $\mathbf{p}=0,000^{* * *}$ \\
\hline Визита 2 & $1,05 \pm 0,87$ & $0,24 \pm 0,17$ & $\mathrm{p}=0,000^{* * *}$ \\
\hline \multicolumn{4}{|l|}{$\mathbf{У}_{\Pi / \text { кре }}$} \\
\hline Визита 0 & $2,76 \pm 2,95$ & $0,30 \pm 0,20$ & $\mathbf{p}=0,000 * * *$ \\
\hline Визита 1 & $1,38 \pm 1,03$ & $0,26 \pm 0,16$ & $\mathbf{p}=0,000 * * *$ \\
\hline Визита 2 & $0,71 \pm 0,507$ & $0,20 \pm 0,07$ & $\mathbf{p}=0,000 * * *$ \\
\hline \multicolumn{4}{|l|}{ НГАЛ /У (ng/ ml) } \\
\hline Визита 0 & $173,25 \pm 172,12$ & $18,75 \pm 10,76$ & $\mathbf{p}=0,000 * * *$ \\
\hline Визита 1 & $73,29 \pm 48,76$ & $14,69 \pm 6,27$ & $\mathbf{p}=0,000 * * *$ \\
\hline Визита 2 & $49,60 \pm 72,57$ & $13,35 \pm 10,22$ & $\mathbf{p}=0,000 * * *$ \\
\hline
\end{tabular}

$* * * p<0,001$

Праћени параметри из урина у свим визитама, били су статистички значајно различити међу групама $(\mathrm{p}<0,001)$. Добијена је статистички значајна разлика за 24ч протеинурију у свим визитама, а имајући у виду да смо поредили групу са активним ЛН и групу код које је болест била у ремисији. Још један од параметара за активност ЛН представљен у виду односа протеина у урину и креатинина (Уп/кр ) био је сигнигфикантно различит између група. Средња вредност уринарног НГАЛ -а је износила за Групу 1/А 173,25 $\pm 172,12$ $\mathrm{ng} / \mathrm{ml}$, а у групи 2/P 18,75 $\pm 10,76 \mathrm{ng} / \mathrm{ml}$ у иницијалној визити. Овако висока 
СД објашњава се великим разликама у нивоу у/НГАЛ у обе групе. У Групи 1/А ниво у/ НГАЛ се кретао од 772,3 до 28,4 ng/ml, а у Групи 2/Р од 42 до $2,1 \mathrm{ng} / \mathrm{ml}$.

На графиконима од 1 - 8, приказани су само статистички значајни лабораторијски параметри који су поређени између група по визитама

Графикон 1 - Поређење средњих вредности укупних протеина између $1 /$ и $2 /$ Р групе у све три визите

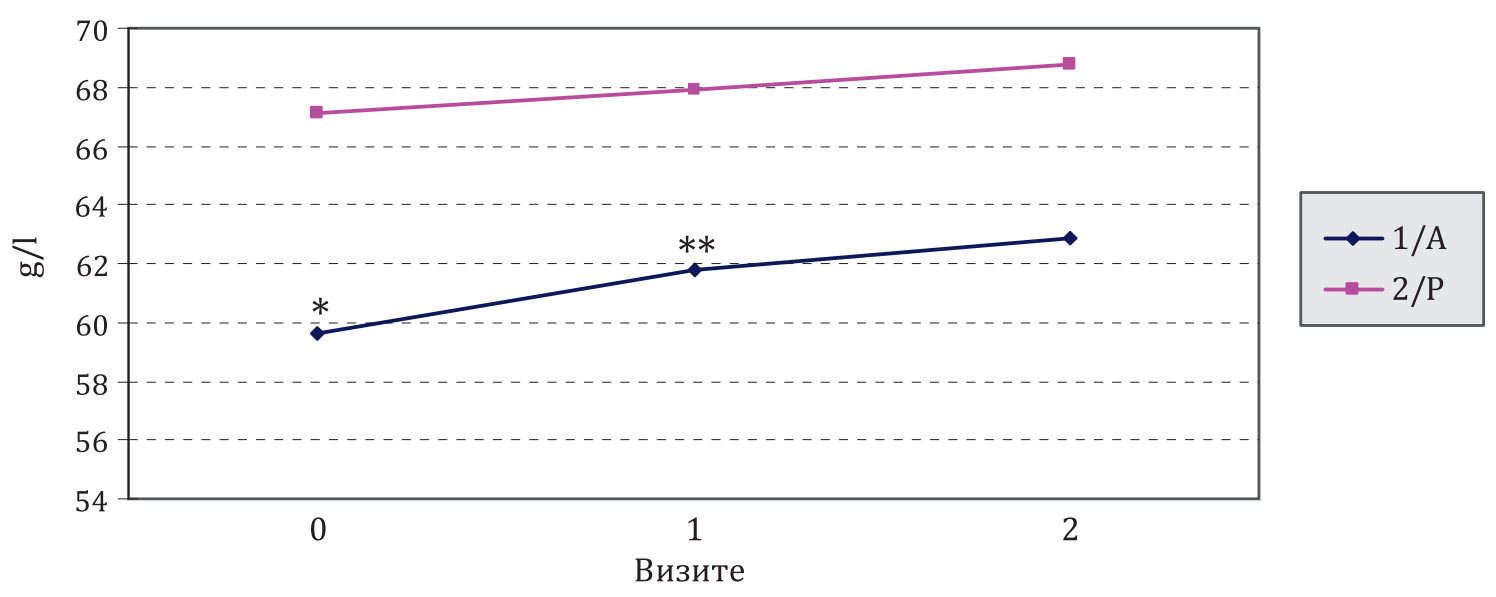

Поређење (визите):

0:0 p- 0,013*

$1: 1$ p- 0,006**

$2: 2 \mathrm{HC}$

Графикон 2 - Поређење средњих вредности албумина између 1/А и 2/Р групе у све три визите

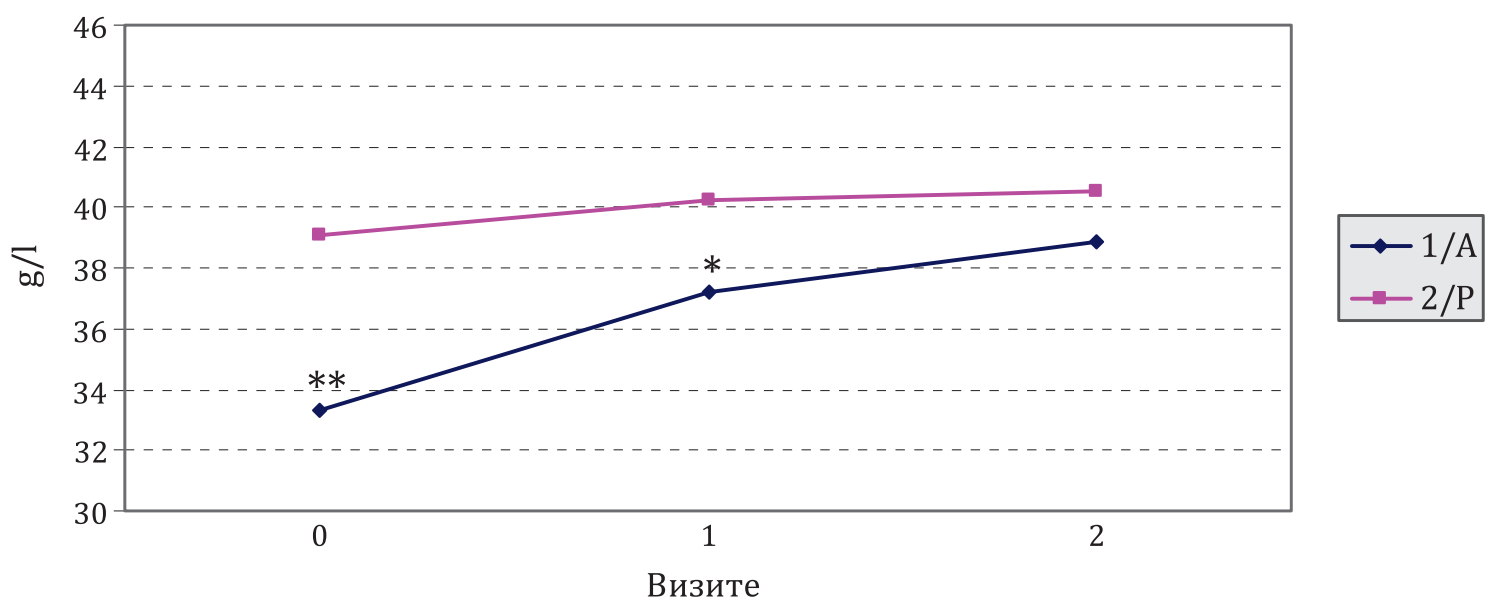

Поређење (визите):

${ }^{*} \mathrm{p}<0,05 ;{ }^{* *} \mathrm{p}<0,01$

$0: 0 \mathbf{p}=0,007^{* *}$

$1: 1 \mathrm{p}=0,040$ *

2:2 HC 
Графикон 3 - Поређење средњих вредности ЦЗ комплемента, између 1/А и 2/Р групе у све три визите

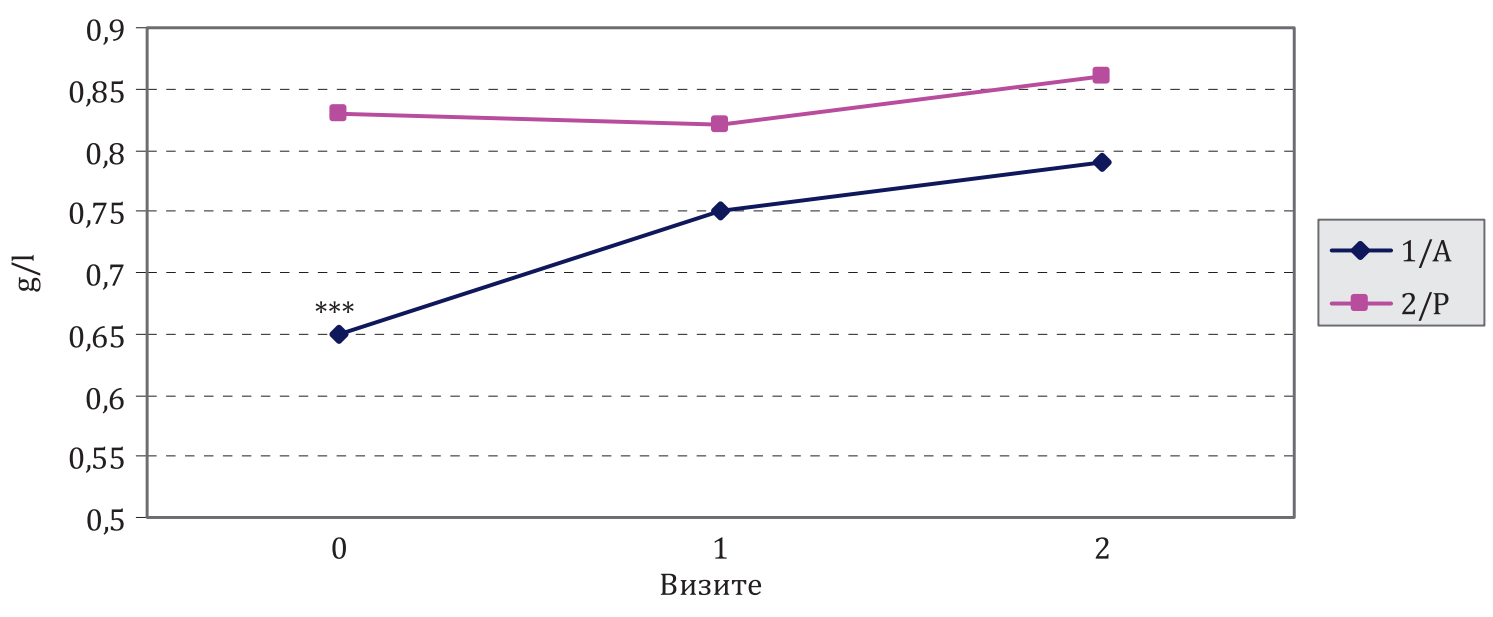

Поређење (визите):

$0: 0 \mathbf{p}=\mathbf{0 . 0 0 0}{ }^{* * *}$

поређење осталих визита НС

Графикон 4 - Поређење средњих вредности анти дс ДНА антитела између 1/А и 2/Р групе у све три визите

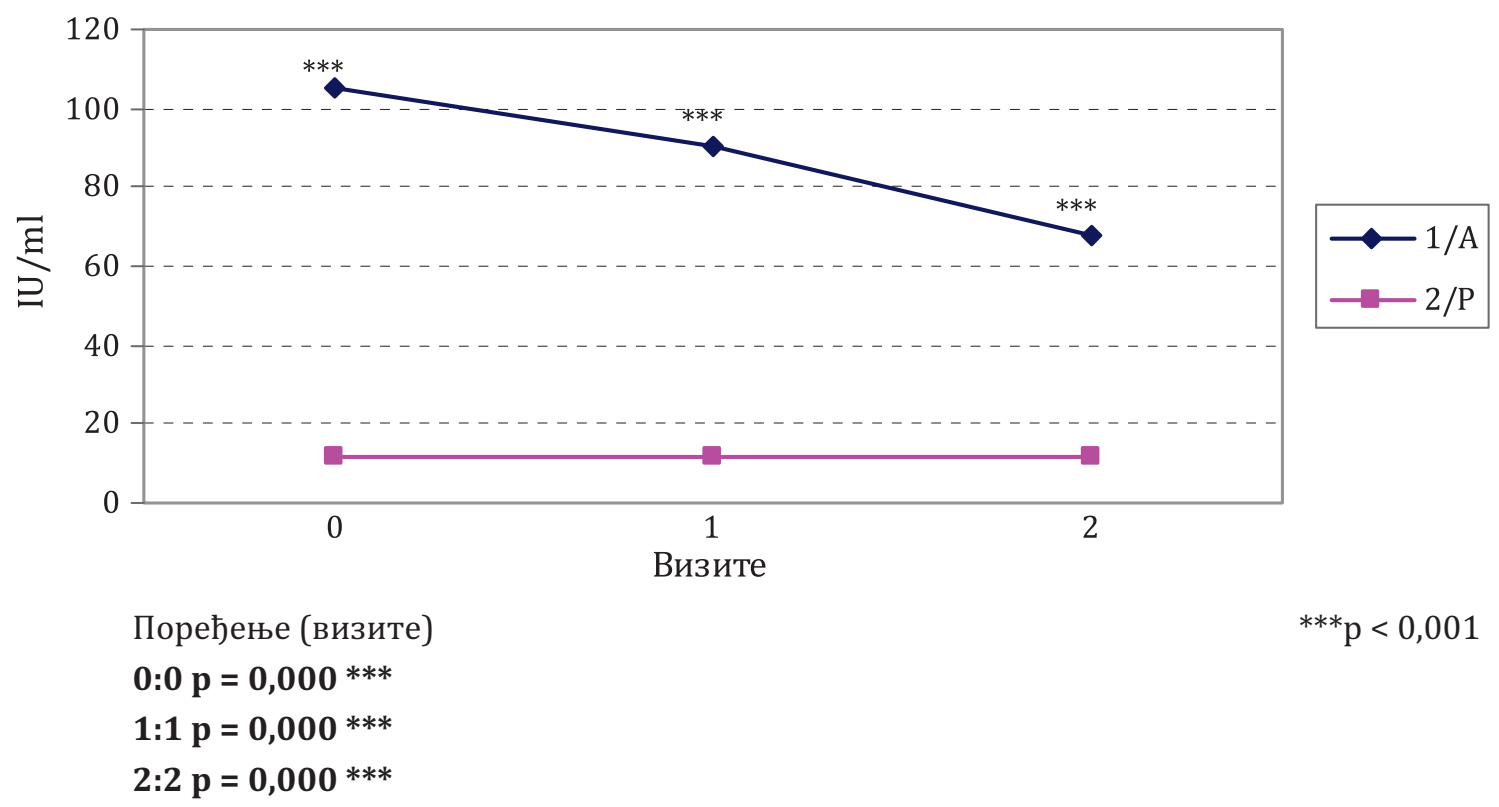

Добијена је статистички значајна разлика у свим визитама поређењем средњих вредности анти дс ДНА антитела. 
Графикон 5 - Поређење средњих вредности 24ч. протеинурије између 1/А и 2/Р групе у све три визите

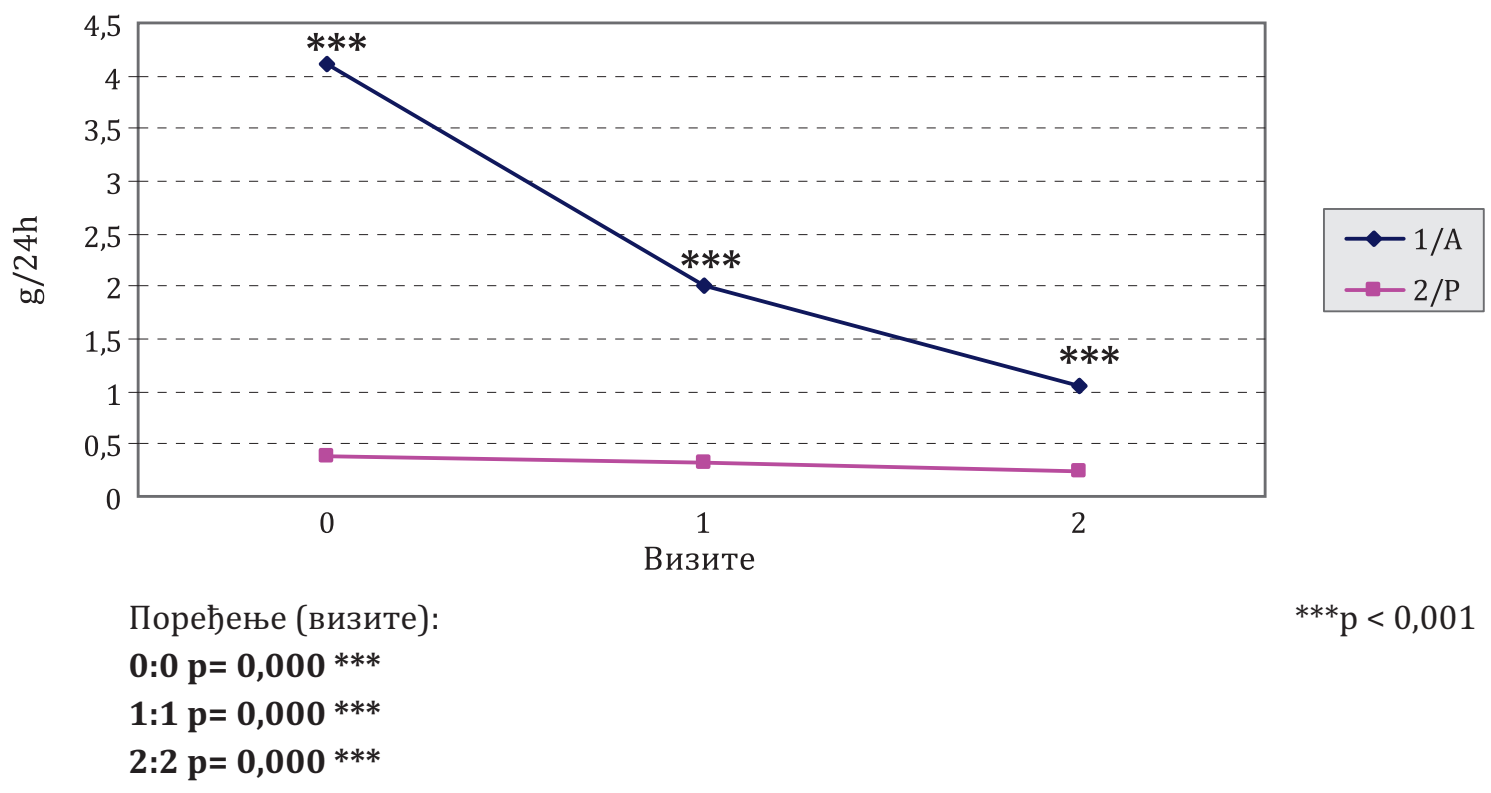

Добијена је статистички значајна разлика између група у свим визитама за протеинурију што је и очекивано, јер је поређена група са активном болешћу и група код које је ЛН у ремисији.

Графикон 6 - Поређење средњих вредности СЛЕДАИ/р између 1/А и 2/Р групе у све три визите

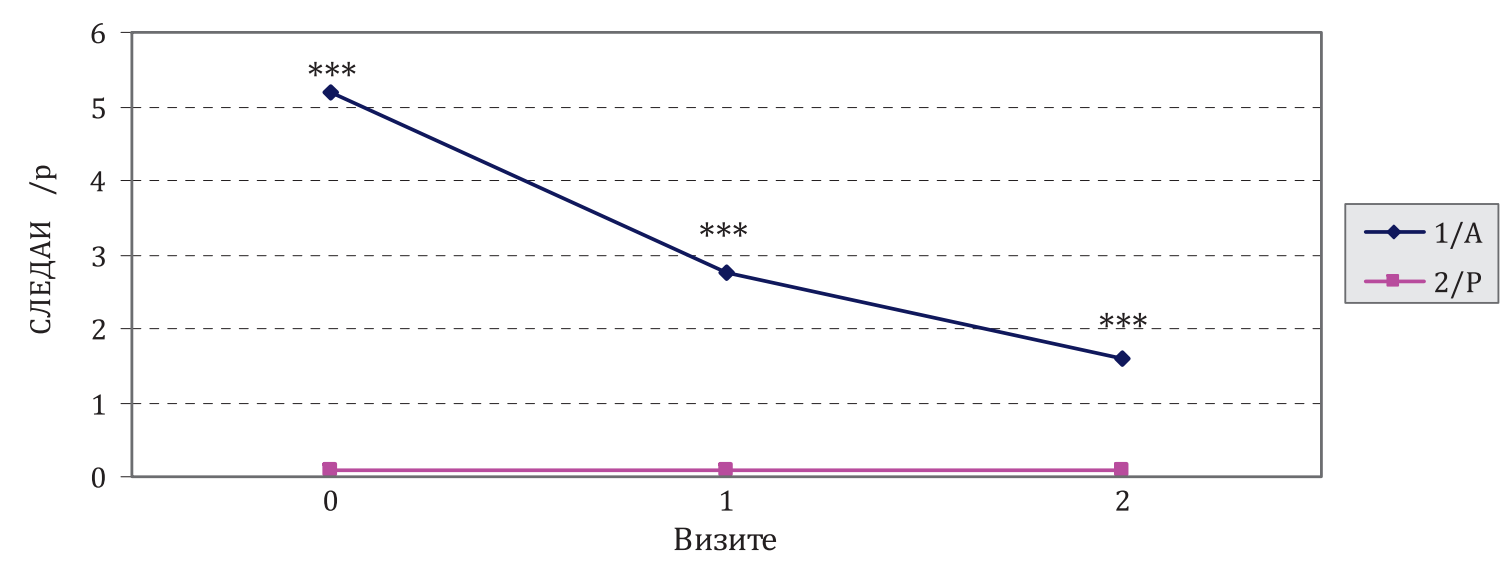

Поређење (визите):

$0: 0 \mathrm{p}=0,000^{* * *}$

$1: 1 \mathrm{p}=0,000^{* * *}$

$2: 2 \mathrm{p}=0,000^{* * *}$ 
Графикон 7 - Поређење средњих вредности односа уринарних протеина и креатинина између 1/А и 2/Р групе у све три визите

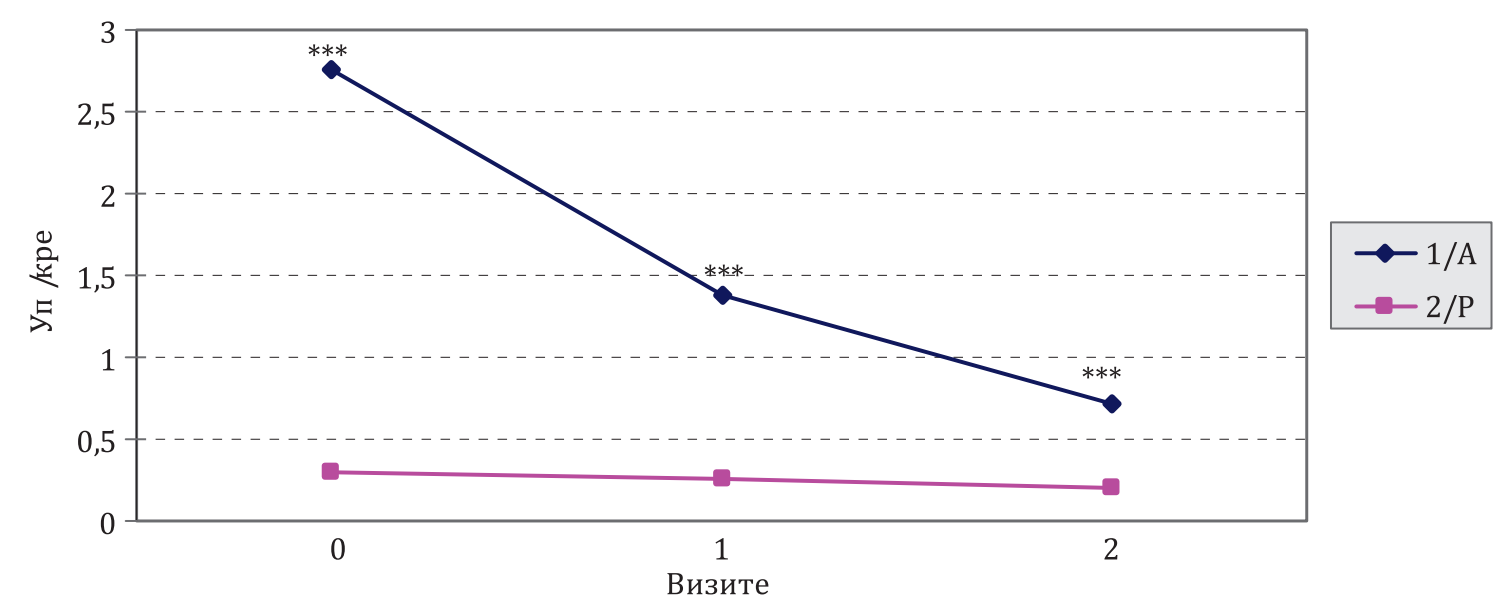

Поређење (визита):

$* * * \mathrm{p}<0,001$

$0: 0 \mathrm{p}=0,000^{* * *}$

$1: 1 \mathrm{p}=0,000^{* * *}$

$2: 2 \mathrm{p}=0,000^{* * *}$

Графикон 8 - Поређење средњих вредности у/НГАЛ између

$1 /$ и и $2 /$ Р групе у све три визите

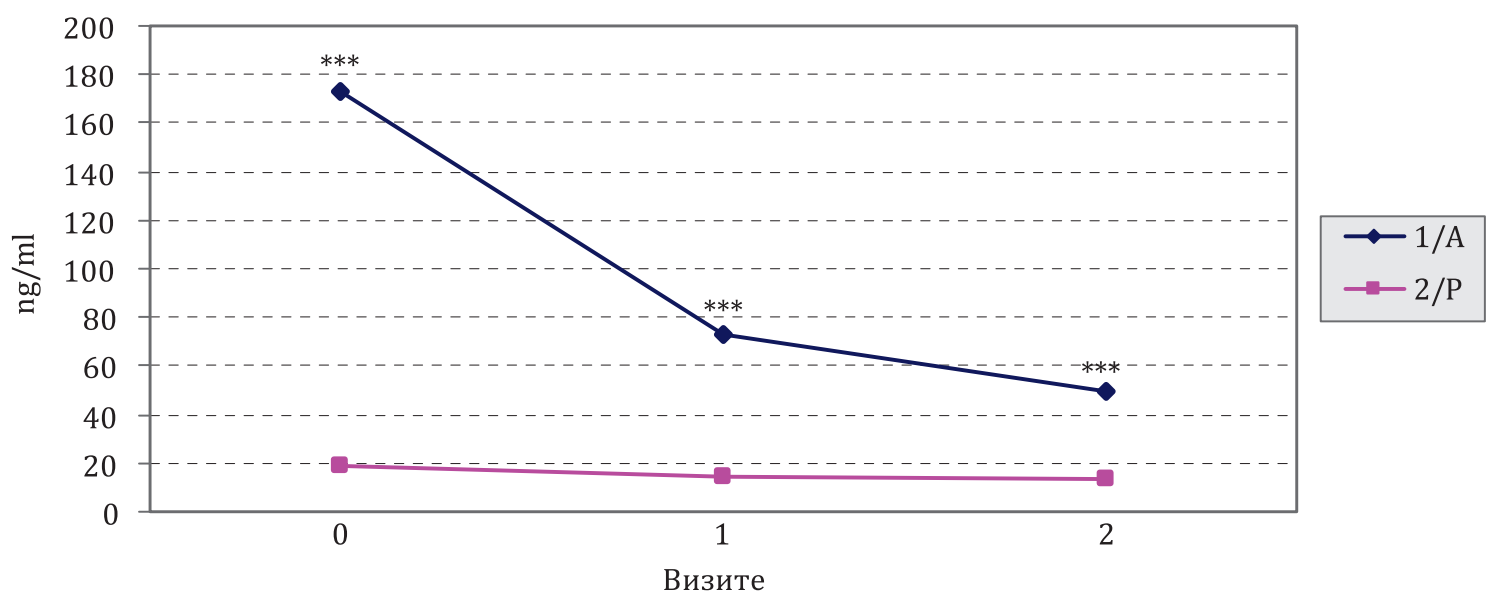

Поређење (визита):

$* * * \mathrm{p}<0,001$

$0: 0 \mathbf{p}=0,000^{* * *}$

$1: 1 \mathrm{p}=0,000^{* * *}$

$2: 2 \mathrm{p}=0,000^{* * *}$

Поређењем средње вредности у/НГАЛ упоредно између група на 2 месеца (укупно 3 визите) коришћењм Mann-Whitney U testa закључујемо да је унутар групе 1/А статистички значајно смањење у/НГАЛ, као и смањење СЛЕДАИ/р скора, 24ч. протеинурије, и Уп/кр. 


\subsection{3. Појединачни прикази лабораторијских параметара за болеснике обе групе}

На следећим графиконима приказани су појединачни лабораторијски резултати за параметре који су били статистички значајно различити по визитама, за сваког од 20 болесника из групе са активним ЛН (1/А) и из групе у ремисији (2/P).

Графикон 9 - Приказ вредности албумина појединачно за сваког болесника у групи $1 / \mathrm{A}$

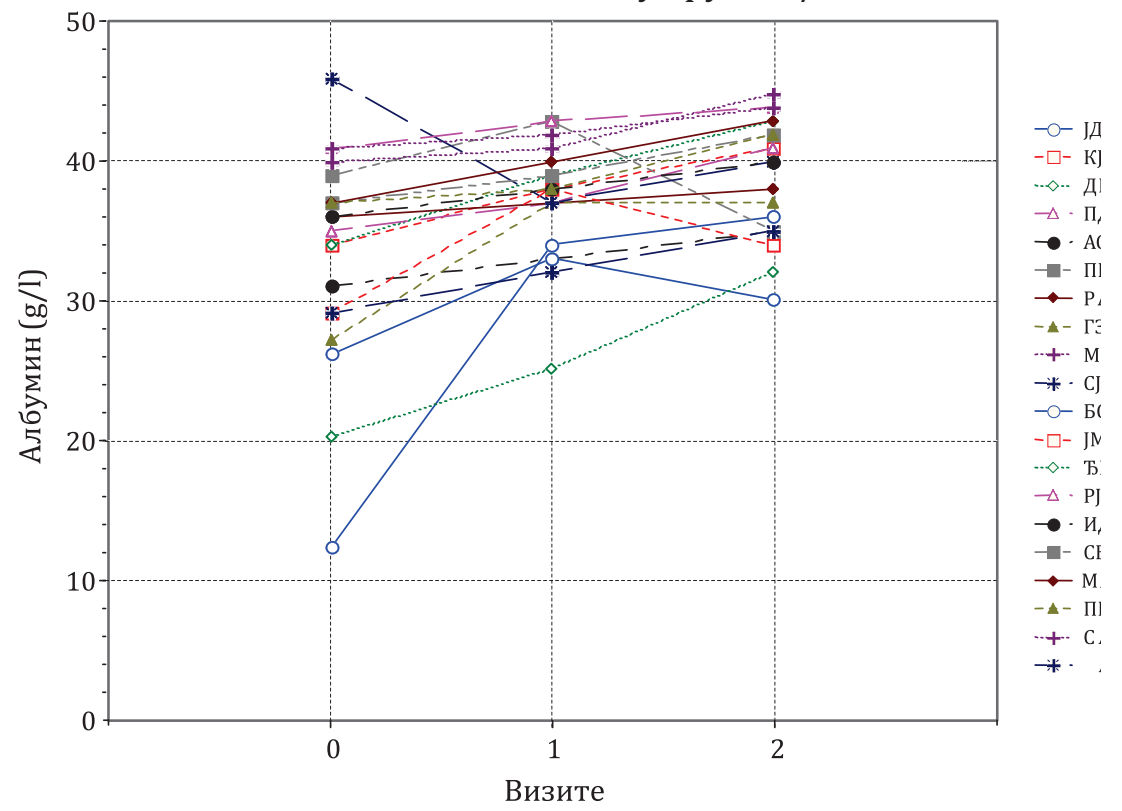

Графикон 10 - Приказ вредности албумина појединачно за сваког болесника у групи 2/P

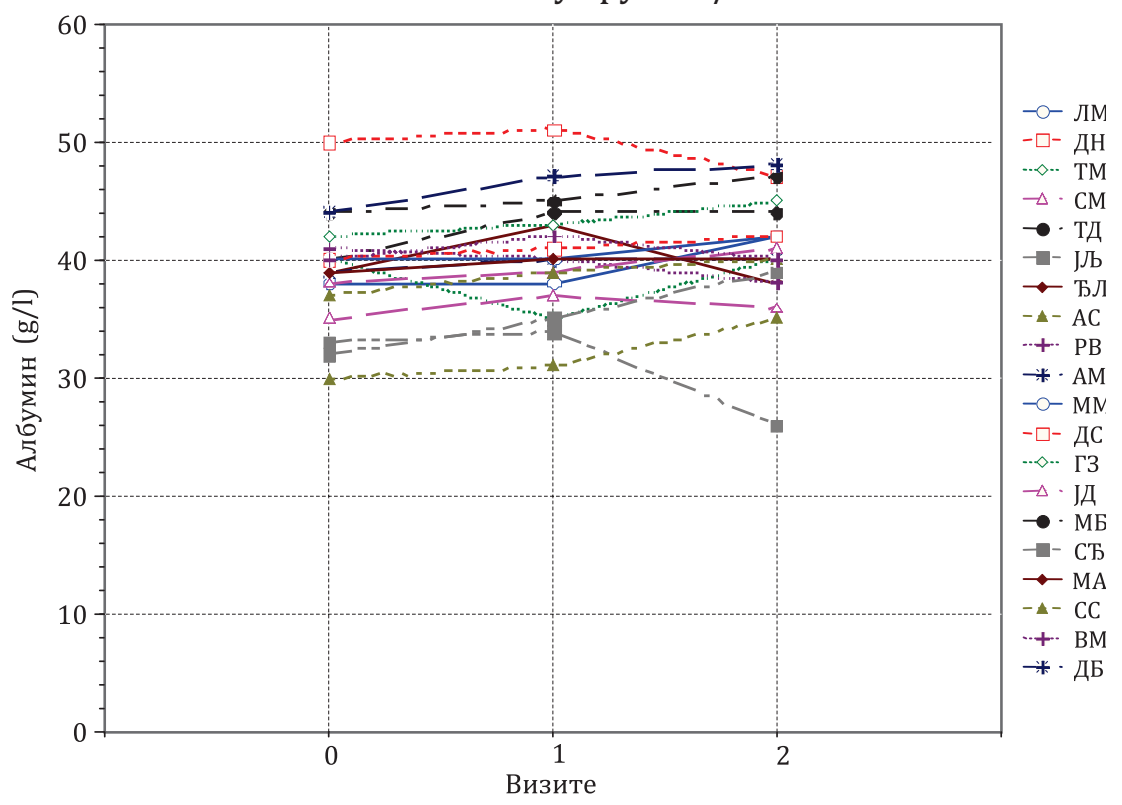


Запажамо да се ниво албумина у серуму између болесника ове две групе разликовао значајно у нултој визити (група 1/A 33,35 \pm 7,88 g/l, група 2/P 39,05 \pm 4,45 g/l ) и у првој визити (1/A: 37,20 \pm 4,25 g/l; 2/P: 40,20 $\pm 4,67$ g/l), док је у трећој та разлика незначајна.

Графикон 11 - Приказ вредности анти дс ДНА антитела посебно за сваког болесника у групи $1 / \mathrm{A}$

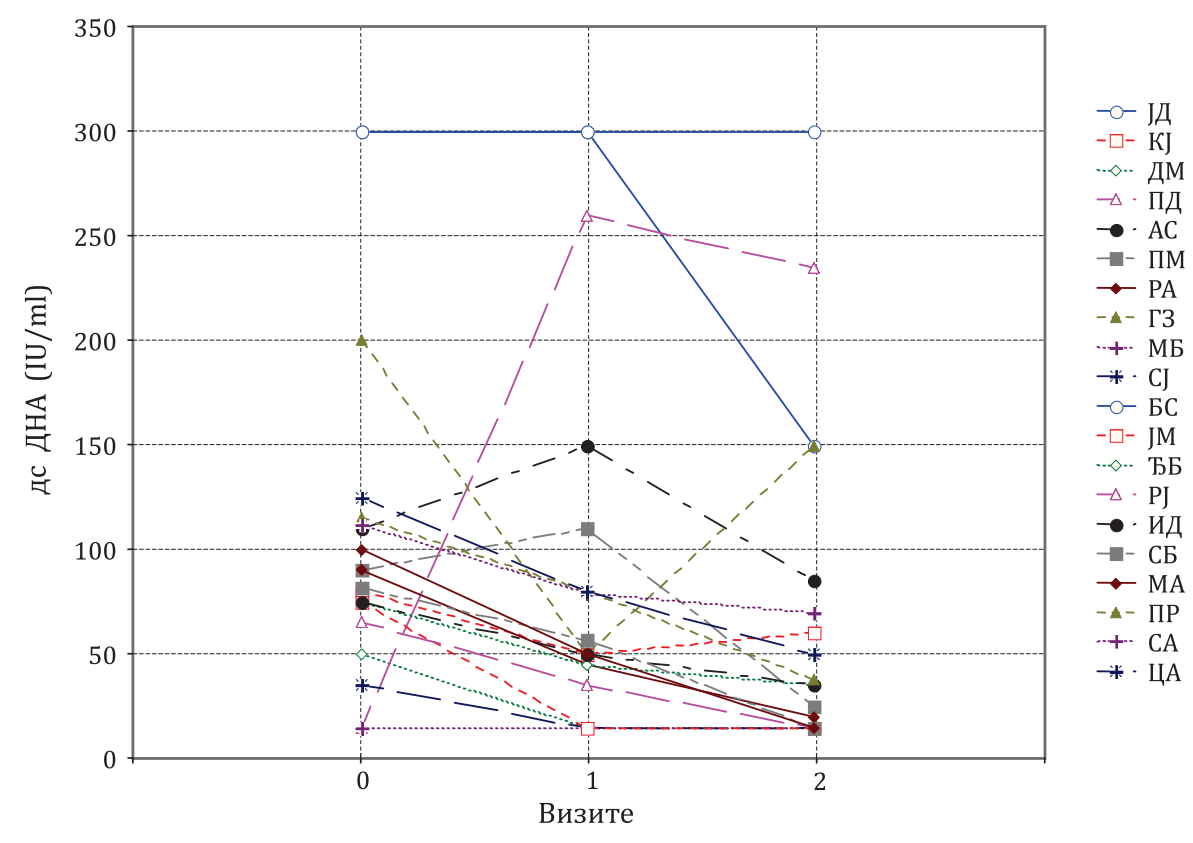

Графикон 12 - Приказ вредности анти дс-ДНА Ат посебно за сваког болесника у групи $2 / \mathrm{P}$

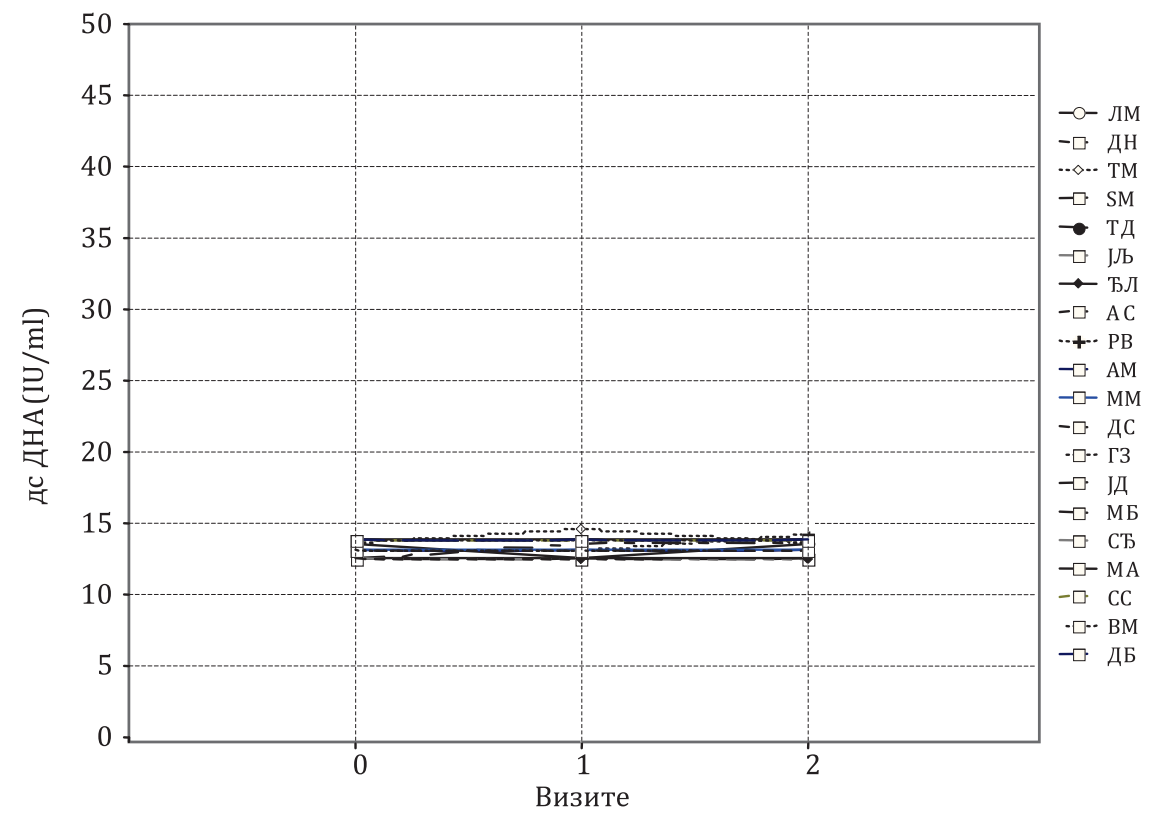


Посматрајући појединачне резултате за анти дс-ДНА антитела у групи 1/А запажа се вредност до $300 \mathrm{IU} / \mathrm{ml}$ у нултој визити, а у визити 2- након 4 месеца (уз одговарајућу терапију) код неких болесника ниво дс-ДНА антитела износи и $15 \mathrm{IU} / \mathrm{ml}$ (што је гранична-референтна вредност). У групи 2/Р вредности су углавном биле до $15 \mathrm{IU} / \mathrm{ml}$, при чему су код неких болесника биле идентичне и представљене су у Графикону 12 јединственом линијом.

Графикон 13 - Приказ вредности 24ч. протеинурије посебно за сваког болесника у групи $1 / \mathrm{A}$

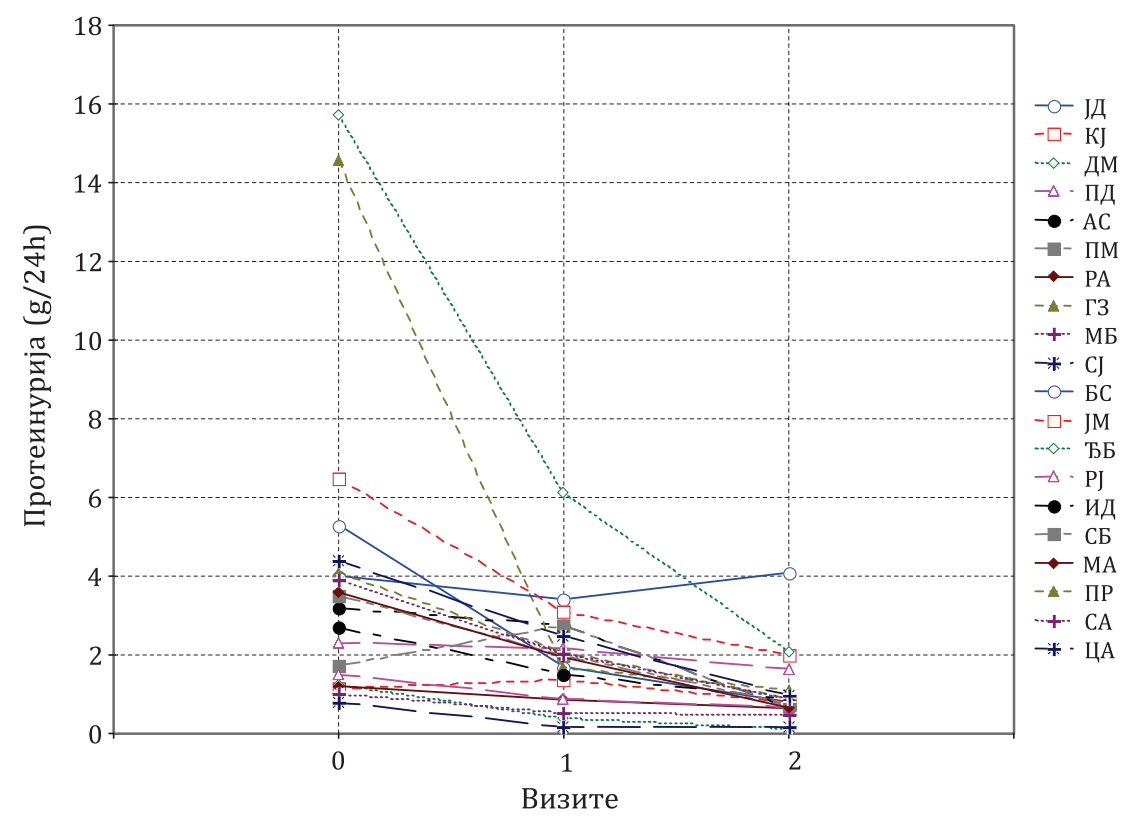

Графикон 14 - Приказ вредности 24ч. протеинурије посебно за сваког болесника у $1 / \mathrm{P}$

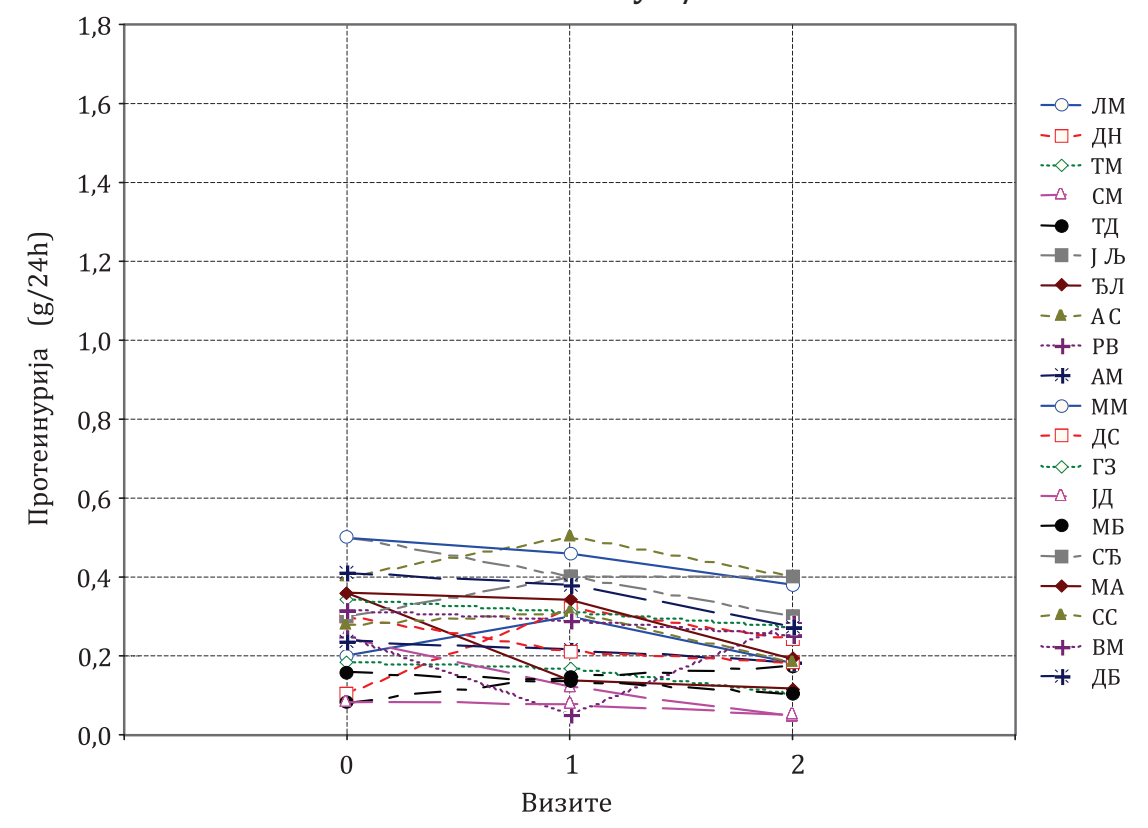


Протеинурија је у групи 1/А била од 15,75 g/24h иницијално, до 0,150 $\mathrm{g} / 24 \mathrm{~h}$ у другој визити за неке болеснике, док су у групи 2/Р протеинурије биле до $0,500 \mathrm{~g} / 24 \mathrm{~h}$.

Графикон 15 - Приказ индекса СЛЕДАИ/р посебно за сваког болесника у групи $1 / \mathrm{A}$

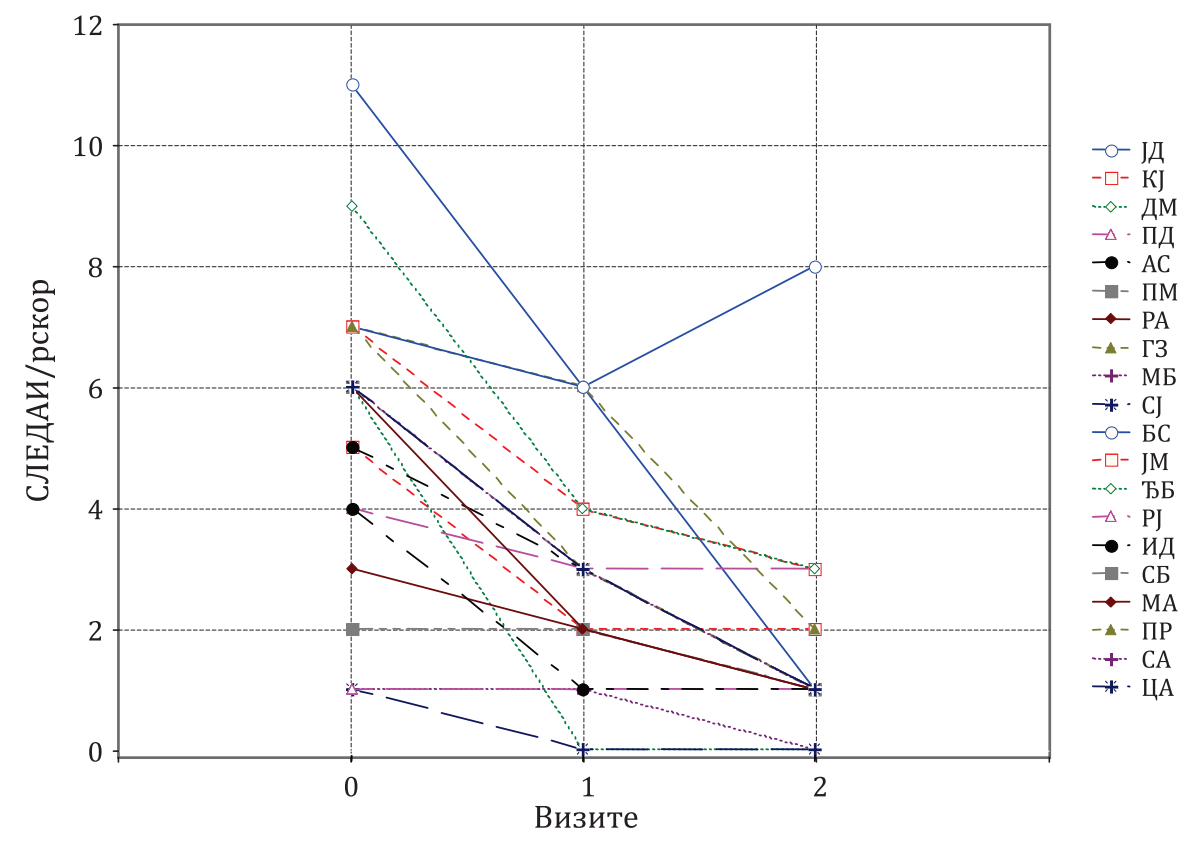

Графикон 16 - Приказ индекса СЛЕДАИ/р посебно за сваког болесника у групи $2 / \mathrm{P}$

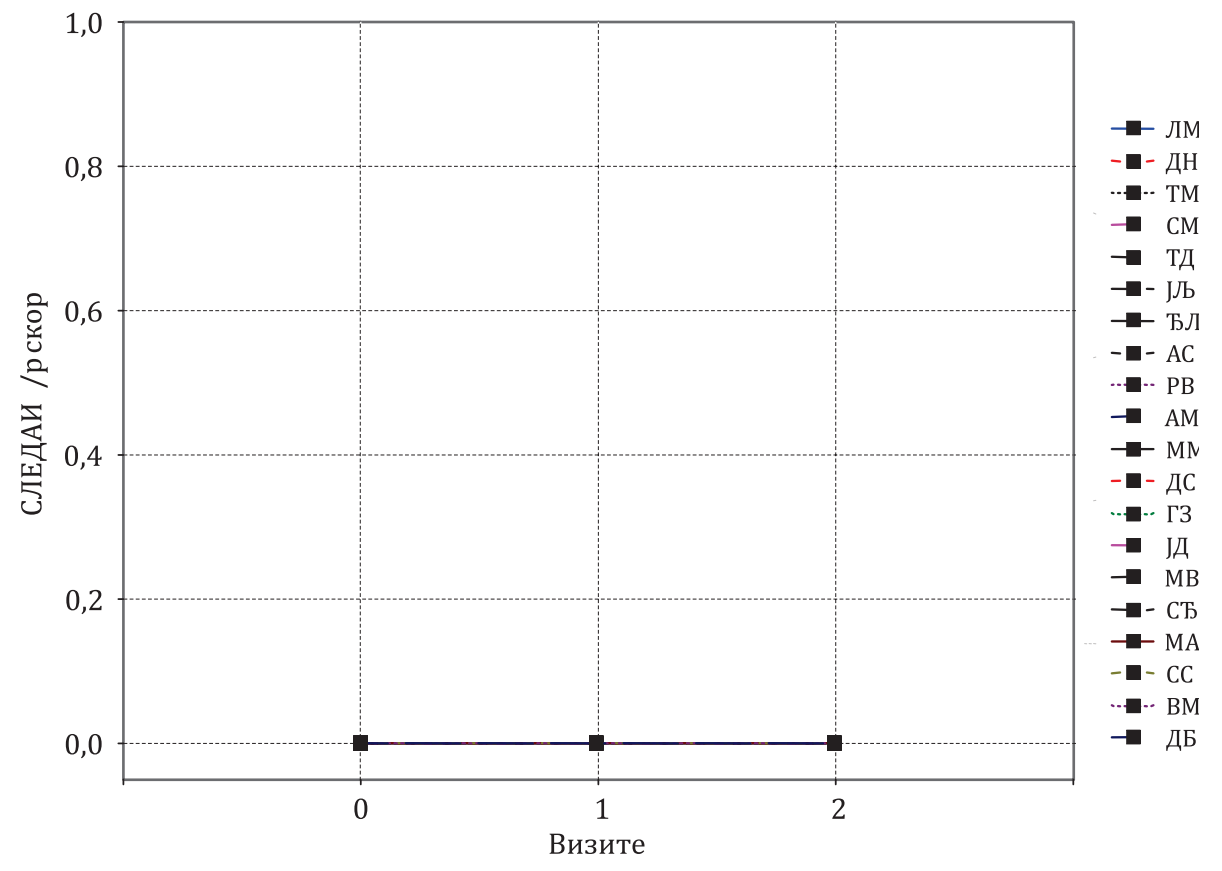


У групи 1/А индекс бубрежне активности СЛЕ: СЛЕДАИ/р износио је од 1-11 у нултој визити, док је код 20 болесника у групи 2/Р била идентична вредност СЛЕДАИ/р представљена јединственом линијом.

Графикон 17 - Приказ односа УП/кре, посебно за сваког болесника у групи 1/А

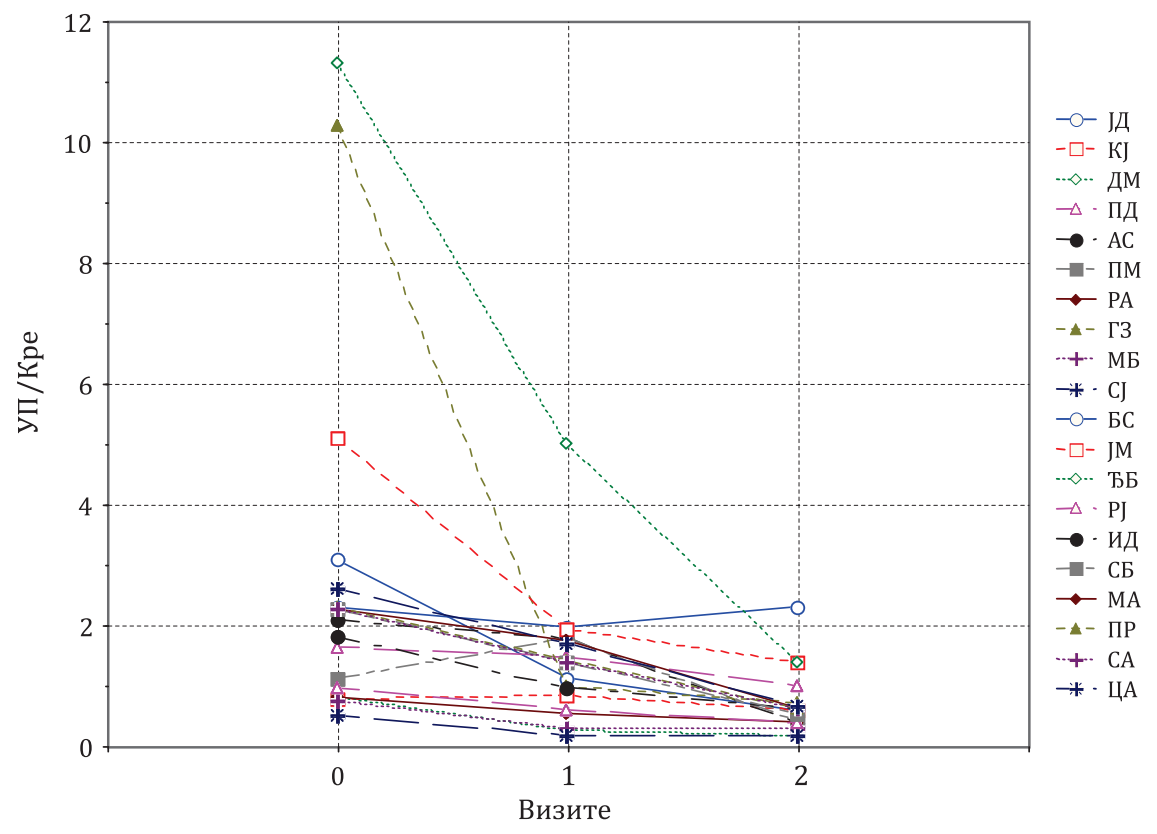

Графикон 18 - Приказ односа УП/кре, посебно за сваког болесника у групи 2/Р

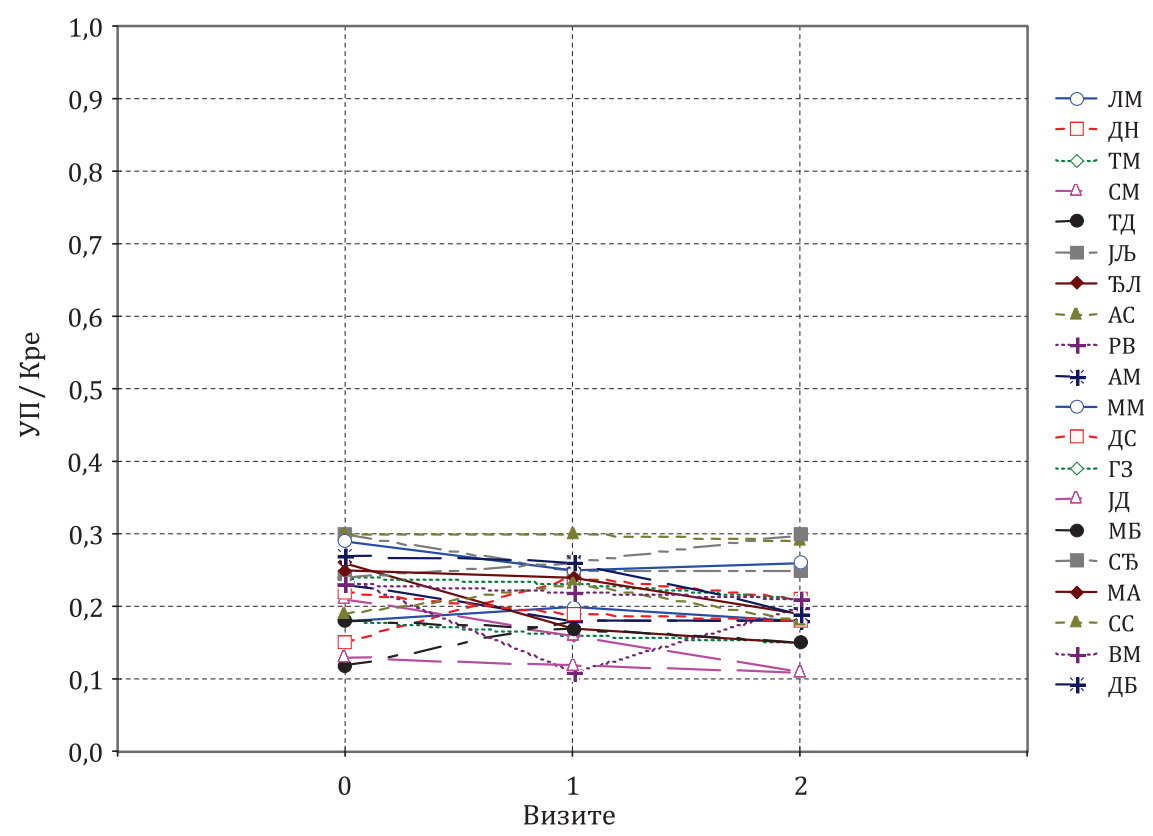

Однос Уп/кре између болесника је у групи 1/А износио је до 11,0 док је код болесника са стабилном ремисијом у групи 2/Р износио до 0,30 у нултој визити. 
Графикон 19 - Приказ у/НГАЛ посебно за сваког болесника у групи 1/А

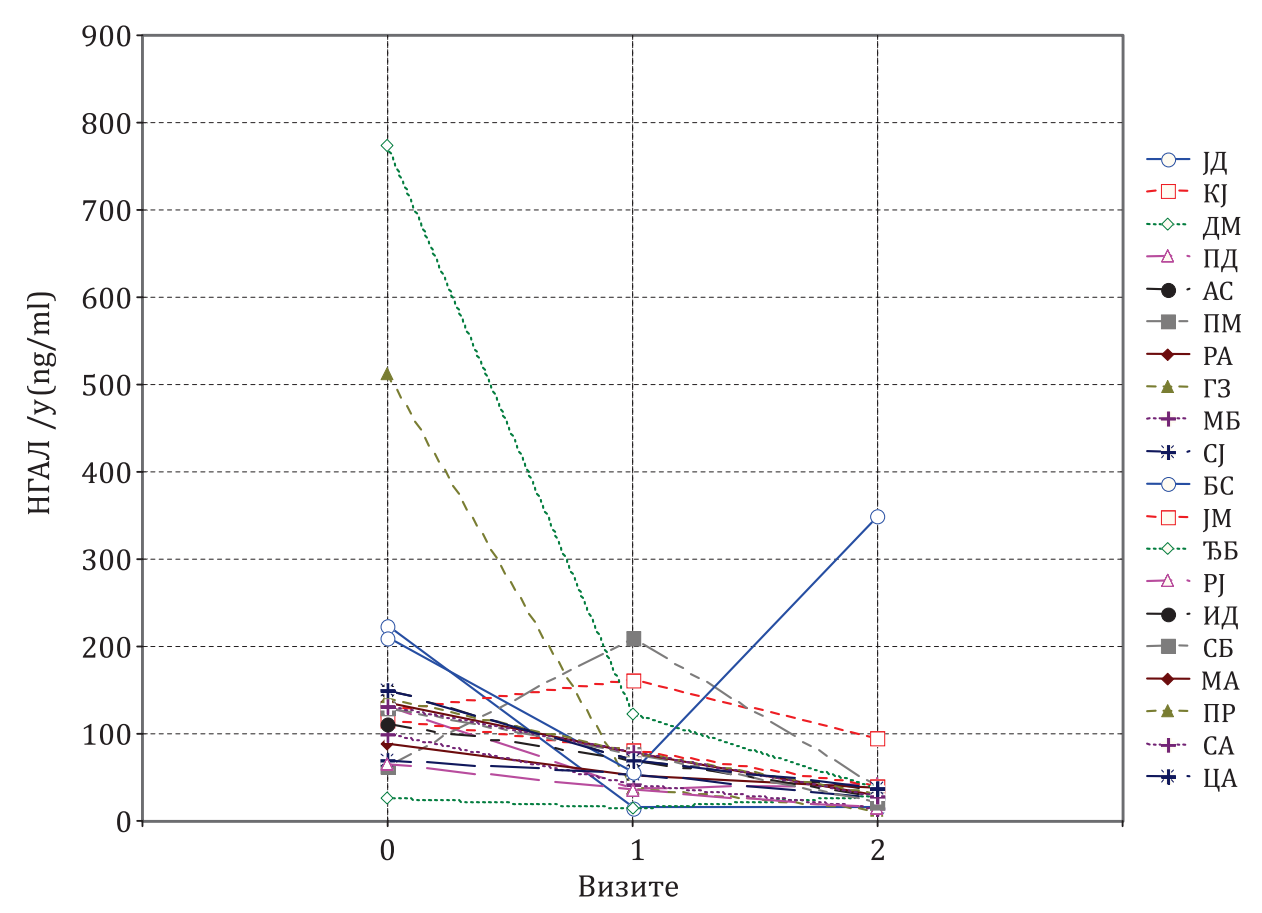

Графикон 20 - Приказ у/НГАЛ посебно за сваког болесника у групи 2/Р

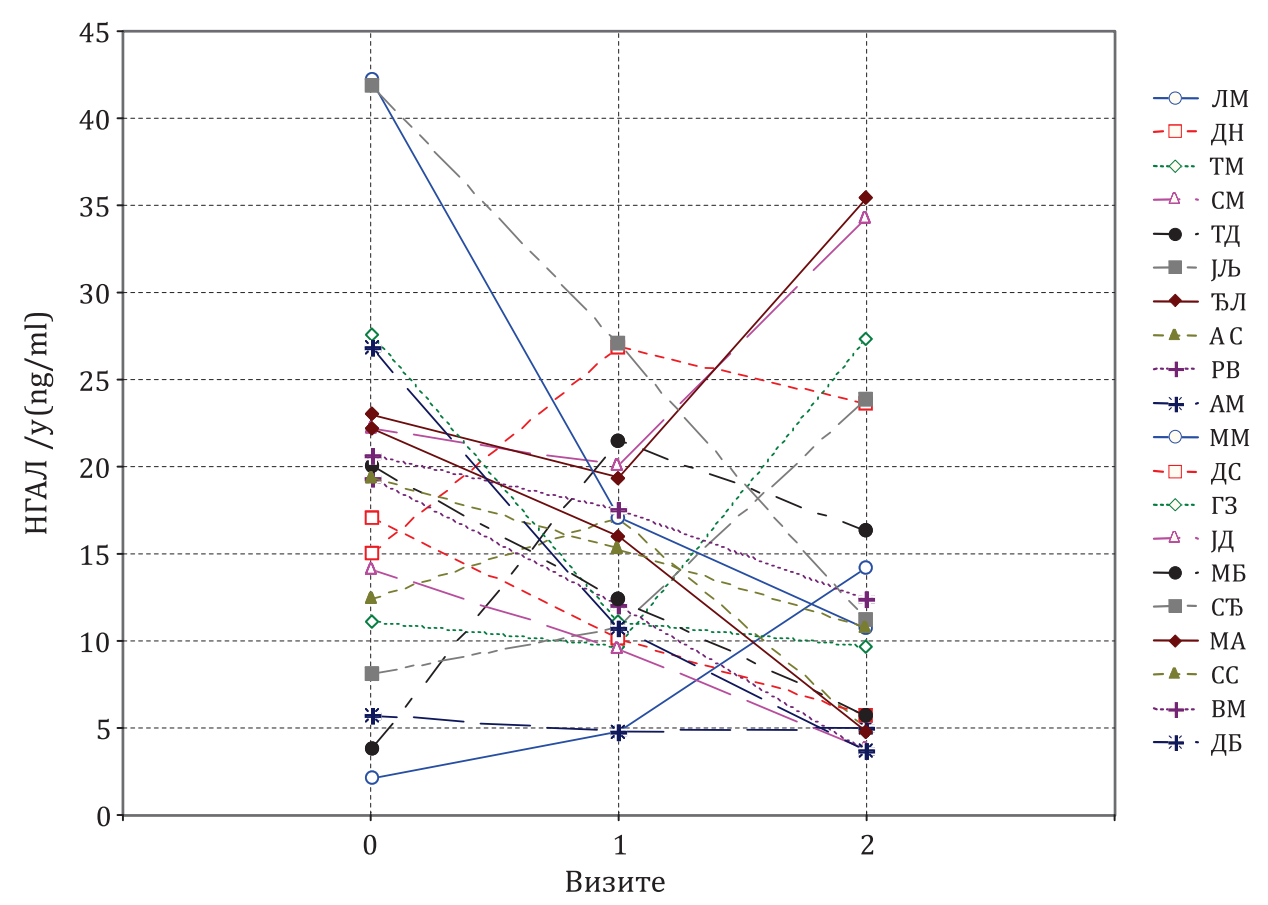

Појединачне вредности у/НГАЛ у групи 1/А биле су од $770 \mathrm{ng} / \mathrm{ml}$ до $63 \mathrm{ng} / \mathrm{ml}$ у нултој визити, док су вредности у 2/Р групи просечно износиле у нултој визити $18,75 \pm 10,76 \mathrm{ng} / \mathrm{ml}$, до $13,35 \pm 10,22 \mathrm{ng} / \mathrm{ml}$ у другој визити. 


\section{2. Поређење података унутар група по визитама}

\subsection{1. Група 1/А: Поређење средњих вредности праћених лабораторијских параметара по визитама}

Табела 11 - Лаб. параметари у групи 1/А по визитама и њихова разлика

\begin{tabular}{|c|c|c|c|c|}
\hline \multicolumn{5}{|c|}{$1 / \mathrm{A}(\overline{\mathrm{X}} \pm$ СД $)$} \\
\hline Лаб.парам/с & Визита 0 & Визита 1 & Визита 2 & $\begin{array}{l}\text { Kruskal Wallis } \\
\text { H test/ANOVA }\end{array}$ \\
\hline ЦРП (mg/L) & $5,66 \pm 6,17$ & $4,42 \pm 3,45$ & $3,47 \pm 0,61$ & $\begin{array}{l}0: 1 \mathrm{HC} \\
0: 2 \mathrm{HC}\end{array}$ \\
\hline Ep x10^12/L & $4,02 \pm 0,68$ & $4,25 \pm 0,48$ & $4,25 \pm 0,46$ & $\begin{array}{l}0: 1 \mathrm{HC} \\
0: 2 \mathrm{HC}\end{array}$ \\
\hline Хб (g/L) & $111,16 \pm 15,10$ & $120,30 \pm 13,03$ & $121,45 \pm 12,25$ & $\begin{array}{l}0: 1 \mathrm{HC} \\
0: 2 \mathrm{HC}\end{array}$ \\
\hline Лe x $10^{\wedge}$ 9/L & $6,00 \pm 2,02$ & $7,14 \pm 2,49$ & $6,50 \pm 2,08$ & $\begin{array}{l}0: 1 \mathrm{HC} \\
0: 2 \mathrm{HC}\end{array}$ \\
\hline $\operatorname{Tp} \times 10^{\wedge} 9 / \mathrm{L}$ & $206,55 \pm 55,01$ & $225,10 \pm 42,57$ & $232,60 \pm 42,04$ & $\begin{array}{l}0: 1 \mathrm{HC} \\
0: 2 \mathrm{HC}\end{array}$ \\
\hline Kp (umol/l) & $87,65 \pm 33,09$ & $82,10 \pm 27,86$ & $78,00 \pm 22,59$ & $\begin{array}{l}0: 1 \mathrm{HC} \\
0: 2 \mathrm{HC}\end{array}$ \\
\hline УП (g/l) & $59,65 \pm 9,12$ & $61,80 \pm 5,86$ & $62,85 \pm 5,20$ & $\begin{array}{l}0: 1 \mathrm{HC} \\
0: 2 \mathrm{HC}\end{array}$ \\
\hline Алб (g/l) & $33,35 \pm 7,88$ & $37,20 \pm 4,25$ & $38,85 \pm 4,36$ & $\begin{array}{l}0: 1 \mathrm{p}=0,09 \\
0: 2 \mathbf{p}=\mathbf{0 , 0 1 0}\end{array}$ \\
\hline Хол (mmol/l) & $5,22 \pm 1,36$ & $5,30 \pm 0,95$ & $5,04 \pm 0,81$ & $\begin{array}{l}0: 1 \mathrm{HC} \\
0: 2 \mathrm{HC}\end{array}$ \\
\hline Триг (mmol/l) & $1,53 \pm 0,65$ & $1,55 \pm 0,71$ & $1,55 \pm 0,78$ & $\begin{array}{l}0: 1 \mathrm{HC} \\
0: 2 \mathrm{HC}\end{array}$ \\
\hline Ц3 (g/l) & $0,65 \pm 0,16$ & $0,75 \pm 0,11$ & $0,79 \pm 0,09$ & $\begin{array}{l}0: 1 \mathbf{p}=\mathbf{0 , 0 3 0} * \\
0: 2 \mathbf{p}=\mathbf{0 , 0 0 2} * * \\
1: 2 \mathrm{p}=0,594\end{array}$ \\
\hline Ц4 (g/l) & $0,09 \pm 0,04$ & $0,11 \pm 0,03$ & $0,18 \pm 0,20$ & $\begin{array}{l}0: 1 \mathrm{HC} \\
0: 2 \mathrm{HC}\end{array}$ \\
\hline $\begin{array}{l}\text { анти дс ДНА } \\
\text { Ат (IU/ml) }\end{array}$ & $105,45 \pm 78,03$ & $90,05 \pm 91,33$ & $67,90 \pm 80,37$ & $\begin{array}{l}0: 1 p=0,46 \\
0: 2 \mathbf{p}=\mathbf{0 , 0 3 3} \\
1: 2 p=0,79\end{array}$ \\
\hline $\begin{array}{l}\text { ГФР/МДРД } \\
\text { (ml/min) }\end{array}$ & $86,52 \pm 29,92$ & $90,50 \pm 29,73$ & $94,65 \pm 25,04$ & $\begin{array}{l}0: 1 \mathrm{HC} \\
0: 2 \mathrm{HC}\end{array}$ \\
\hline КККр (ml/min) & $106,74 \pm 29,23$ & $111,74 \pm 32,97$ & $113,64 \pm 26,30$ & $\begin{array}{l}0: 1 \mathrm{HC} \\
0: 2 \mathrm{HC}\end{array}$ \\
\hline
\end{tabular}

${ }^{*} \mathrm{p}<0,05 ;{ }^{* *} \mathrm{p}<0,01 ;{ }^{* * *} \mathrm{p}<0,001$ 
Поређење података анализом варијансе - АНОВА учињено је за серумски креатинин, албумине, холестерол, триглицериде, клиренс креатинина ГФРМДРД, клиренс креатинина по Кокрофту, комплемент Ц3 и Ц4, док је за остале параметре коришћен Kruskal Wallis H test .

Табела 12 - Лаб. параметри из урина у групи 1/А, праћени по визитама и њихова разлика

\begin{tabular}{|c|c|c|c|c|}
\hline \multicolumn{5}{|c|}{$1 / \mathrm{A}(\overline{\mathrm{X}} \pm \mathrm{CД})$} \\
\hline Лаб. парам/у & Визита 0 & Визита 1 & Визита 2 & $\begin{array}{c}\text { Kruskal Wallis } \\
\text { H test }\end{array}$ \\
\hline $\begin{array}{l}\text { Протеинурија } \\
\text { по Биурету } \\
\text { (g/24h) }\end{array}$ & $4,12 \pm 4,08$ & $2,00 \pm 1,32$ & $1,05 \pm 0,87$ & $\begin{array}{l}0: 1 \mathrm{p}=0,158 \\
0: 2 \mathbf{p}=\mathbf{0 , 0 0 0} * * * \\
1: 2 \mathbf{p}=\mathbf{0 , 0 3 3} *\end{array}$ \\
\hline $\begin{array}{l}\text { Ур.прот / креат. } \\
\text { УП/к }\end{array}$ & $2,76 \pm 2,95$ & $1,38 \pm 1,033$ & $0,71 \pm 0,50$ & $\begin{array}{l}0: 1 p=0,142 \\
0: 2 \mathbf{p}=\mathbf{0 , 0 0 0} * * * \\
1: 2 \mathbf{p}=\mathbf{0 , 0 4 3} *\end{array}$ \\
\hline СЛЕДАИ/p & $5,20 \pm 2,66$ & $2,75 \pm 1,80$ & $1,60 \pm 1,75$ & $\begin{array}{l}0: 1 \mathbf{p}=\mathbf{0 , 0 4 0} * \\
0: 2 \mathbf{p}=\mathbf{0 , 0 0 0} * * * \\
1: 2 \mathrm{p}=0,158\end{array}$ \\
\hline НГАЛ (ng/ml) & $173,25 \pm 172,12$ & $73,29 \pm 46,76$ & $49,60 \pm 72,57$ & $\begin{array}{l}0: 1 \mathbf{p}=\mathbf{0 , 0 2 5} \mathbf{5}^{* *} \\
0: 2 \mathbf{p}=\mathbf{0 , 0 0 0} * * * \\
1: 2 \mathbf{p}=\mathbf{0 , 0 3 5} *\end{array}$ \\
\hline
\end{tabular}

${ }^{*} \mathrm{p}<0,05 ;{ }^{* *} \mathrm{p}<0,01 ;{ }^{* * *} \mathrm{p}<0,001$

Поређењем лабораторијских параметара по визитама на 2 месеца, запажа се очекивано, да у групи 1/А на примењено лечење долази до постепеног повећања нивоа хемоглобина, повећања ук. протеина, албумина, комплемента, смањења холестерола и триглицерида, анти дс-ДНА антитела и 24ч. протеинурије.

Добијена је статистички значајна разлика за серумске албумине, Ц3 комплемент и анти дс ДНА антитела, док су остале разлике биле не сигнификантне.

Међутим поредећи разлике у визитама 0 према 1, 0 према 2, као и 1:2 за уринарне анализе: 24ч протеинурију, СЛЕДАИ/р, однос Уп/кре и у/НГАЛ добијене су статистички значајне разлике. 
Графикон 21 - Поређење средње вредности албумина праћено у визитама - 1/А група /Kruskal Wallis H test /

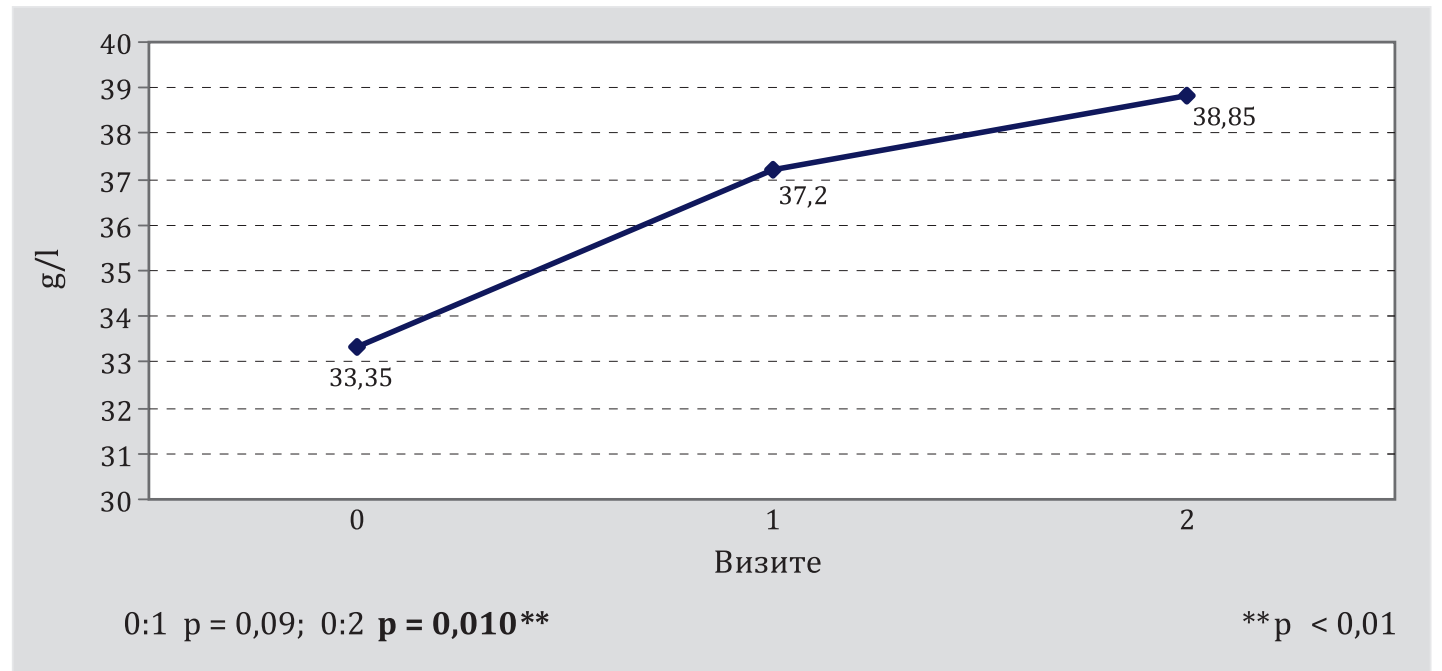

Добијена је статистичка значајност у поређењу нулта визите са другом (пораст нивоа албумина са 33,35 \pm 7,88 g/l на 38,85 \pm 4,36 g/l, што је било очекивано имајући у виду да су то болесници у активној групи ЛН, код којих се спроводи лечење индукционом терапијом.

Сличне резултате добили смо у овој групи поређењем Ц3 комплемента у визитама (Графикон 22)

Графикон 22 - Поређење средње вредности комплемента Ц3 у визитама- 1/А група

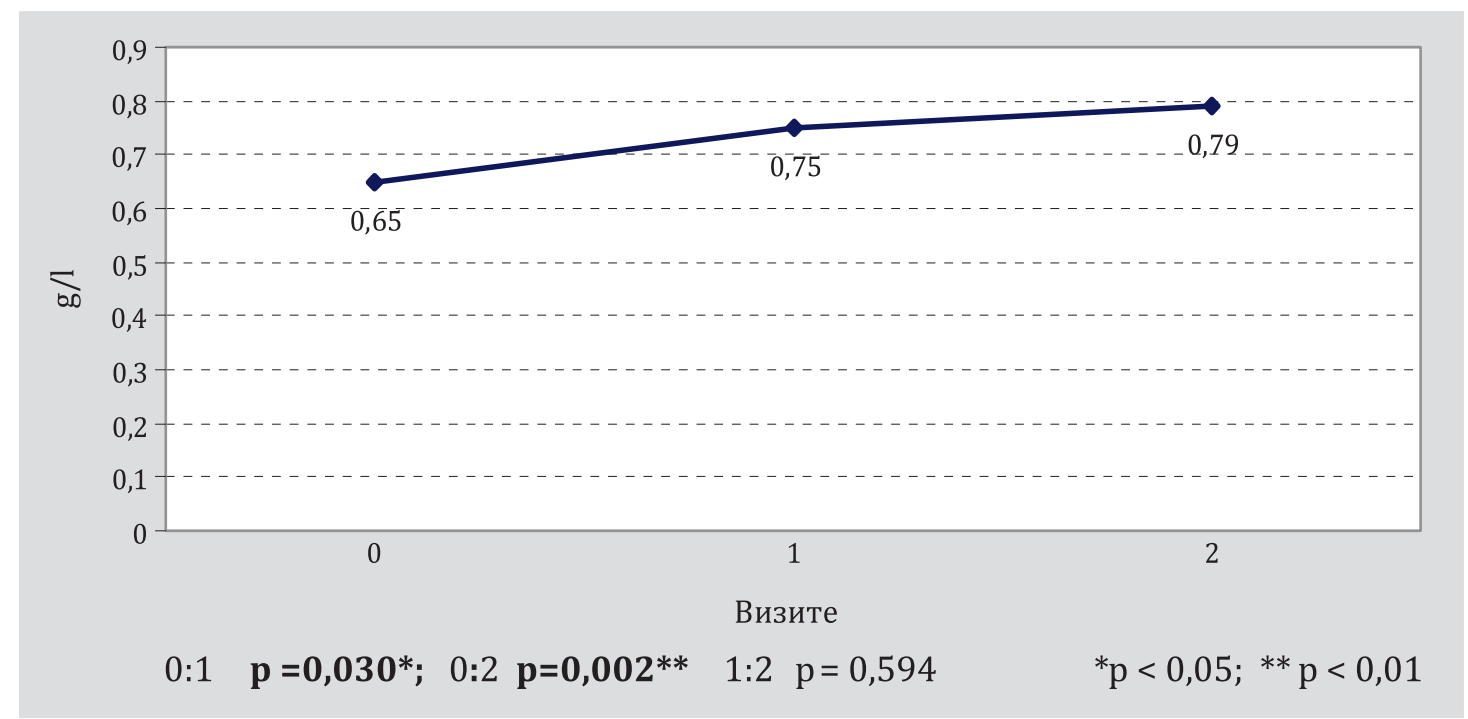

Добијена је статистичка значајност Ц3 у поређењу нулте са првом и нулте са другом визитом. 
Следећи графикон представља поређење анти дс ДНА антитела у визитама и показује статистичку значајност између добијених резултата у визити 0 према визити 2.

Графикон 23 - Поређење средње вредности анти дс ДНА у визитама - 1/А група

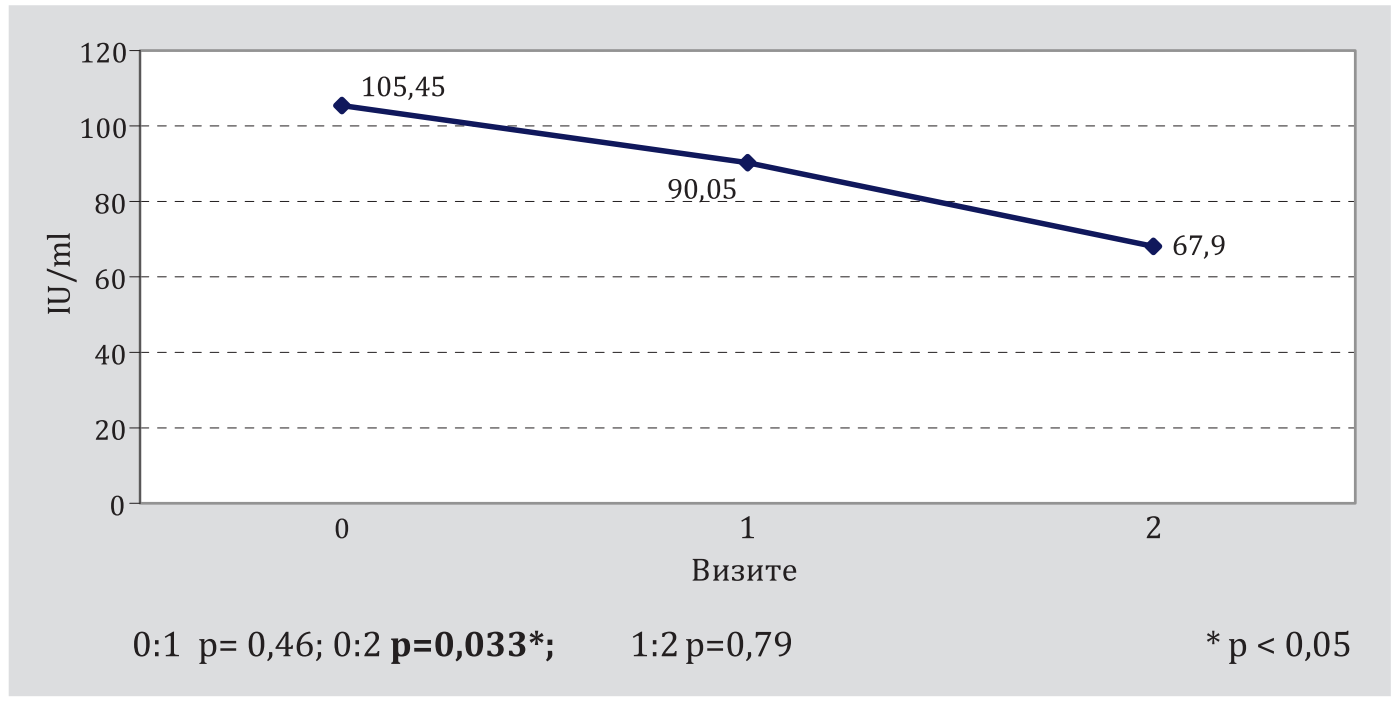

Имајући у виду да су резултати уринарних анализа значајан показатељ активности ЛН у овој групи смо добили резултате који су указали на позитиван ефекат примењеног лечења (протеинурија, СЛЕДАИ/р, Упр/кр и НГАЛ) Графикони 24 -27.

Графикон 24 - Поређење средње вредности протеинурије између визита - 1/А група

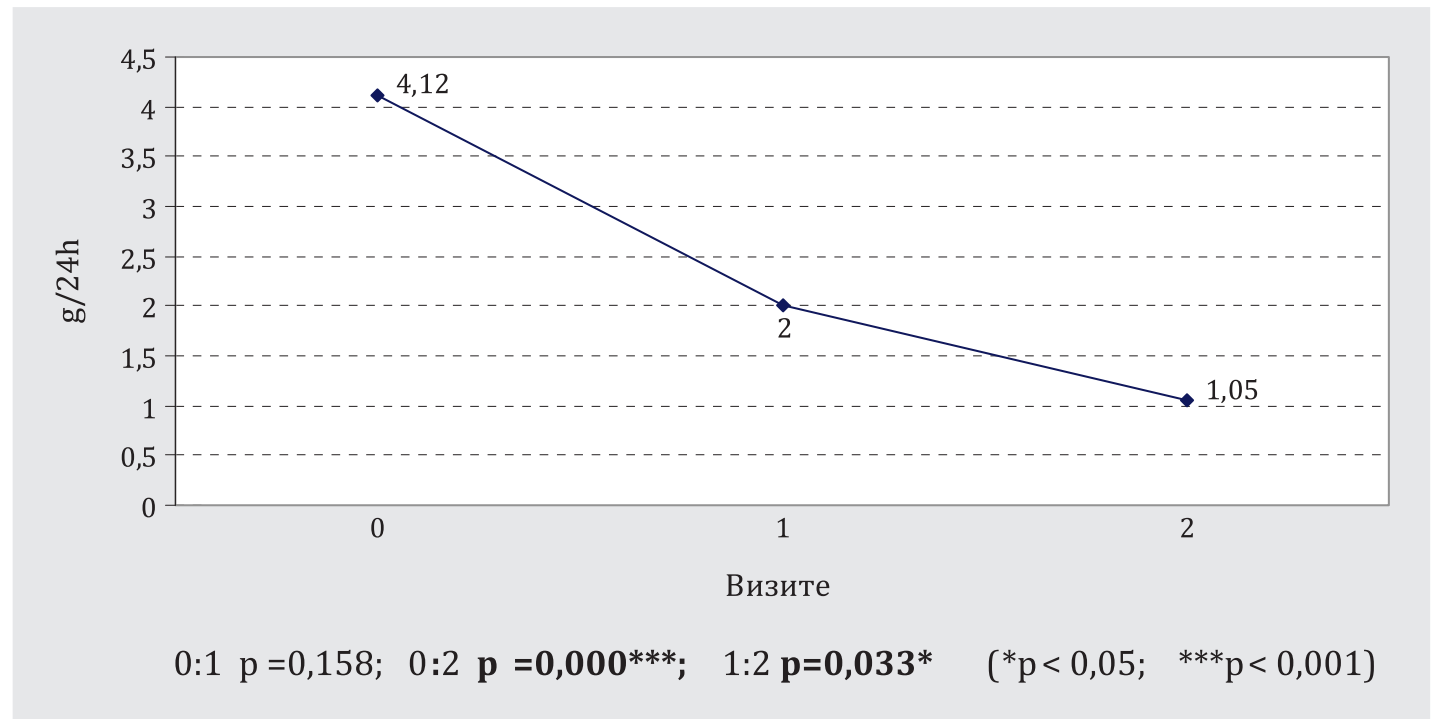


Графикон 25 - Поређење средње вредности СЛЕДАИ/р у визитама - 1/А група

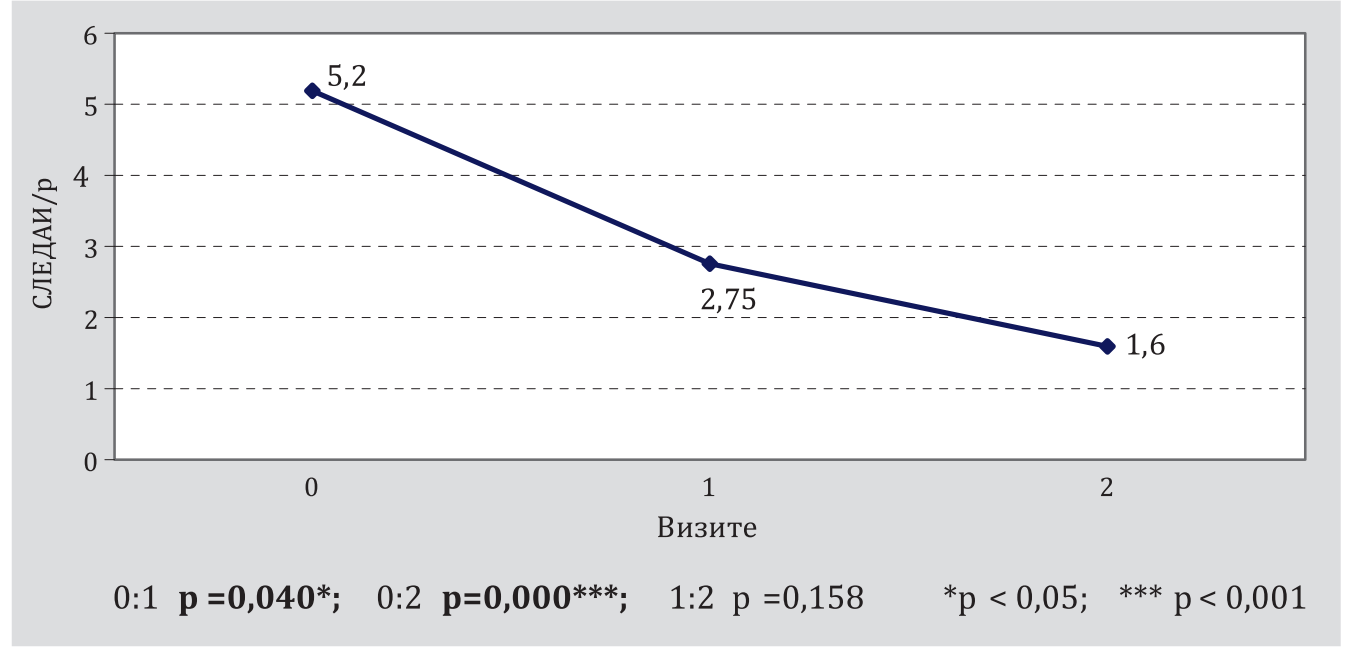

Графикон 26 - Поређење средње вредности односа Уп/кре праћеног у визитама - $1 /$ А група

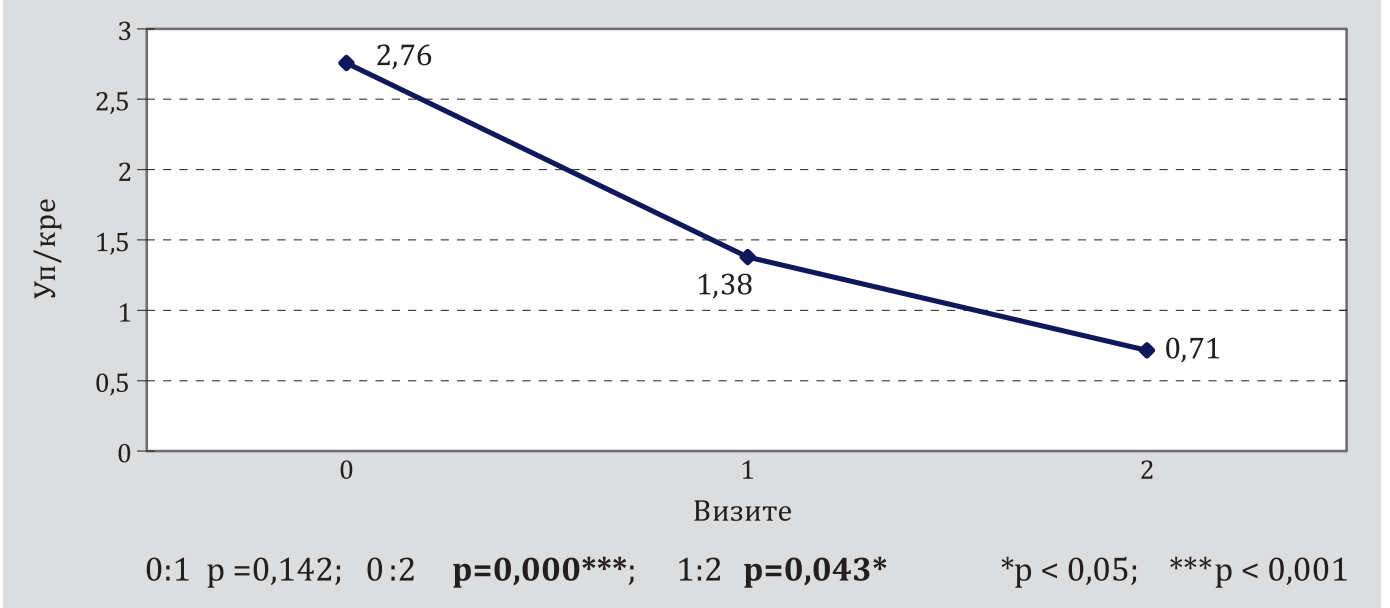

Графикон 27 - Поређење средњих вредности НГАЛ у визитама- 1/А група

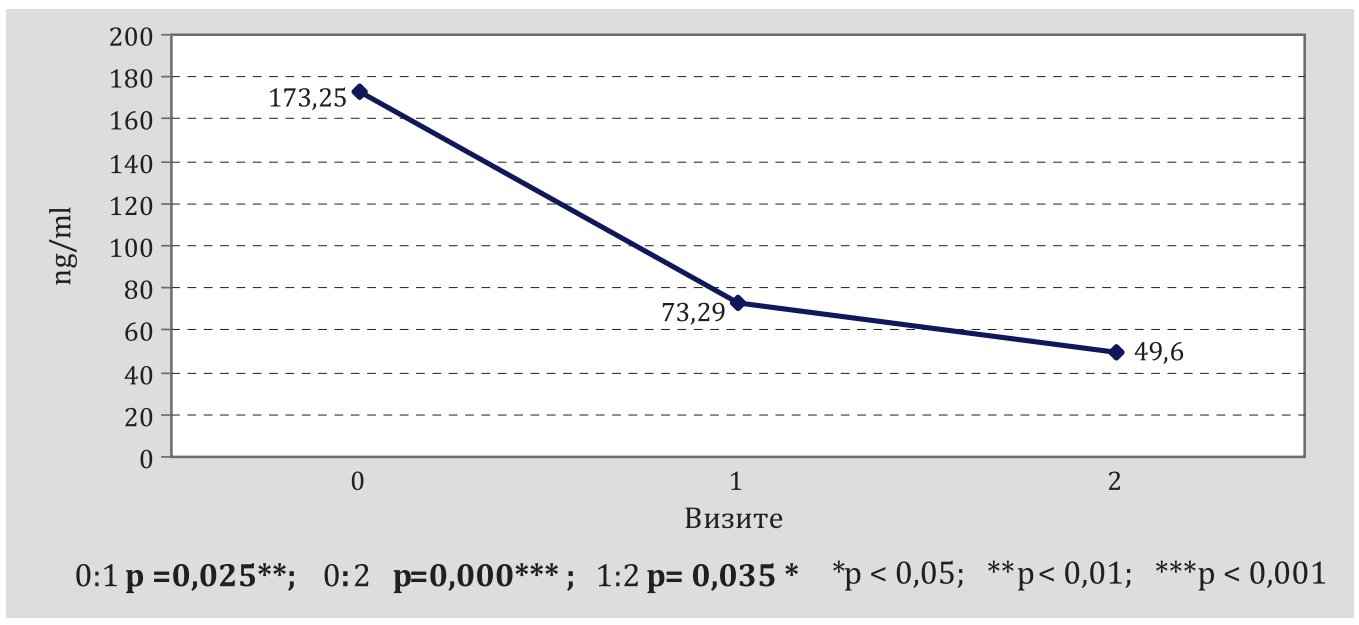


Током праћења, уринарни параметри (24ч. протеинурија, СЛЕДАИ/р, УП/кре, НГАЛ) у групи 1/А, су се статистички значајно смањивали, након започетог лечења (Графикони 24, 25, 26, 27), а посебно је та разлика значајна у поређењу нулте са визитом два.

\subsection{2. Поређење средњих вредности праћених лабораторијских параметара по визитама у групи 2/P}

Табела 13 - Лаб. анализе у групи 2/P ( $\mathrm{X} \pm \mathrm{CД})$ праћене у визитама и њихова разлика

\begin{tabular}{|c|c|c|c|c|}
\hline Параметри/с & Визита 0 & Визита 1 & Визита 2 & $\begin{array}{l}\text { Kruskal Wallis } \\
\text { H test/ANOVA }\end{array}$ \\
\hline ЦРП (mg/L) & $3,75 \pm 1,48$ & $3,16 \pm 0,61$ & $3,48 \pm 2,29$ & $\begin{array}{l}0: 1 \mathrm{HC} \\
0: 2 \mathrm{HC}\end{array}$ \\
\hline $\operatorname{Ep} \times 10^{12} / \mathrm{L}$ & $4,34 \pm 0,47$ & $4,45 \pm 0,44$ & $4,57 \pm 0,41$ & $\begin{array}{l}0: 1 \mathrm{HC} \\
0: 2 \mathrm{HC}\end{array}$ \\
\hline Хб (g/L) & $124,25 \pm 12,83$ & $127,95 \pm 12,12$ & $139,60 \pm 42,03$ & $\begin{array}{l}0: 1 \mathrm{HC} \\
0: 2 \mathrm{HC} \\
\end{array}$ \\
\hline Ле $\times 10^{9} / \mathrm{L}$ & $7,02 \pm 3,58$ & $7,31 \pm 2,69$ & $7,41 \pm 2,82$ & $\begin{array}{l}0: 1 \mathrm{HC} \\
0: 2 \mathrm{HC} \\
\end{array}$ \\
\hline $\mathrm{Tp} \times 10^{9} / \mathrm{L}$ & $248,05 \pm 06,64$ & $251,00 \pm 101,49$ & $264,05 \pm 92,09$ & $\begin{array}{l}0: 1 \mathrm{HC} \\
0: 2 \mathrm{HC} \\
\end{array}$ \\
\hline Kp (umol/l) & $79,15 \pm 19,93$ & $75,45 \pm 16,03$ & $72,15 \pm 16,16$ & $\begin{array}{l}0: 1 \mathrm{HC} \\
0: 2 \mathrm{HC}\end{array}$ \\
\hline УП (g/l) & $67,15 \pm 9,25$ & $67,90 \pm 7,46$ & $68,75 \pm 8,46$ & $\begin{array}{l}0: 1 \mathrm{HC} \\
0: 2 \mathrm{HC} \\
\end{array}$ \\
\hline Алб (g/l) & $39,05 \pm 4,45$ & $40,20 \pm 4,67$ & $40,50 \pm 4,90$ & $\begin{array}{l}0: 1 \mathrm{HC} \\
0: 2 \mathrm{HC}\end{array}$ \\
\hline Хол (mmol/l) & $5,35 \pm 0,81$ & $5,42 \pm 0,95$ & $5,31 \pm 1,26$ & $\begin{array}{l}0: 1 \mathrm{HC} \\
0: 2 \mathrm{HC} \\
\end{array}$ \\
\hline Триг (mmol/l) & $1,54 \pm 0,34$ & $1,50 \pm 0,28$ & $1,44 \pm 0,63$ & $\begin{array}{l}0: 1 \mathrm{HC} \\
0: 2 \mathrm{HC} \\
\end{array}$ \\
\hline Ц3 (g/l) & $0,83 \pm 0,11$ & $0,82 \pm 0,10$ & $0,86 \pm 0,12$ & $\begin{array}{l}0: 1 \mathrm{HC} \\
0: 2 \mathrm{HC} \\
\end{array}$ \\
\hline Ц4 (g/l) & $0, .14 \pm 0,03$ & $0,14 \pm 0,40$ & $0,15 \pm 0,03$ & $\begin{array}{l}0: 1 \mathrm{HC} \\
0: 2 \mathrm{HC} \\
\end{array}$ \\
\hline $\begin{array}{l}\text { анти дс ДНА } \\
\text { Ат IU/ml }\end{array}$ & $12,07 \pm 11,71$ & $12,00 \pm 14,43$ & $11,82 \pm 31,26$ & $\begin{array}{l}0: 1 \mathrm{HC} \\
0: 2 \mathrm{HC}\end{array}$ \\
\hline $\begin{array}{l}\text { ГФР/МДРД } \\
\text { (ml/min) }\end{array}$ & $88,61 \pm 29,69$ & $88,74 \pm 25,88$ & $94,63 \pm 29,13$ & $\begin{array}{l}0: 1 \mathrm{HC} \\
0: 2 \mathrm{HC}\end{array}$ \\
\hline КККр(ml/min) & $103,33 \pm 23,39$ & $110,61 \pm 23,34$ & $111,20 \pm 24,66$ & $\begin{array}{l}0: 1 \mathrm{HC} \\
0: 2 \mathrm{HC}\end{array}$ \\
\hline
\end{tabular}


Поређење података анализом варијансе - AHOBА учињено је за креатинин, албумине, холестерол, триглицериде клиренс креатинина ГФР-МДРД, КККр, Ц3, Ц4, док је за остале параметре коришћен Kruskal-Wallis H test. Поређење лабораторијских анализа у табели 13 није указало на статистичку значајност.

Табела 14 - Лаб. анализе у урина за групу 2/P ( $\overline{\mathrm{X}} \pm$ СД) праћене у визитама и њихова разлика

\begin{tabular}{|c|c|c|c|c|}
\hline Параметри/ у & Визита 0 & Визита 1 & Визита 2 & $\begin{array}{c}\text { Kruskal } \\
\text { Wallis Htest }\end{array}$ \\
\hline $\begin{array}{l}\text { Протеинурија по } \\
\text { Биурету (g/24h) }\end{array}$ & $0,39 \pm 0,35$ & $0,33 \pm 0,27$ & $0,24 \pm 0,17$ & $\begin{array}{l}0: 1 \mathrm{HC} \\
0: 2 \mathrm{HC} \\
1: 2 \mathrm{HC}\end{array}$ \\
\hline $\begin{array}{l}\text { Уринарни прот / } \\
\text { креат. Уп/кре }\end{array}$ & $0,30 \pm 0,21$ & $0,26 \pm 0,16$ & $0,20 \pm 0,07$ & $\begin{array}{l}0: 1 \mathrm{HC} \\
0: 2 \mathrm{HC} \\
1: 2 \mathrm{HC}\end{array}$ \\
\hline СЛЕДАИ/p & $0,00 \pm 0,00$ & $0,00 \pm 0,00$ & $0,00 \pm 0,00$ & $\begin{array}{l}0: 1 \mathrm{HC} \\
0: 2 \mathrm{HC} \\
1: 2 \mathrm{HC}\end{array}$ \\
\hline НГАЛ (ng/ml) & $18,75 \pm 10,76$ & $14,69 \pm 6,27$ & $13,35 \pm 10,22$ & $\begin{array}{l}0: 1 \mathrm{HC} \\
0: 2 \mathrm{HC} \\
1: 2 \mathrm{HC}\end{array}$ \\
\hline
\end{tabular}

Група 2/Р није имала статистички значајне промене у средњим вредностима праћених лабораторијских параметара у серуму и у урину што је разумљиво јер је то група болесника који су у стабилној ремисији. Ови болесници су одржавали стабилну ремисију све време праћења, а на то указује 24ч. протеинурија, налаз у седименту урина који је приказан преко СЛЕДАИ/р, као и однос УП/кре. Средња вредност у/НГАЛ у овој групи болесника је такође статистички незначајна, што корелира са осталим параметрима. Ниво у/НГАЛ је значајно нижи у односу на групу 1/А.

\section{3. Поређење разлика између група 1/A и 2/P}

Досадашњи преглед изнетих резултата у табелама и графиконима, посебно у оним у којима су међусобно поређане вредности 2/Р групе, не може у потпуности расветлити реалну слику динамике неких битних, праћених параметара у периоду од 0-2 визите. Разлог за то је чињеница да се почетне (базалне) вредности током 0 визите често статистички значајно разликују 
између група па је неопходно утврдити \% промена вредности параметара у односу на 0 промену за сваку групу понаособ, а затим их подесним статистичким анализама упоредити: Студентов т- тест (t-test) и алтернативно Ман-Витнијев У тест (Mann-Whitney U test) .

Табела 15 - Поређење значајности разлика између група 1/А и 2/Р у визитама 0-2

\begin{tabular}{|c|c|c|c|}
\hline \multirow{2}{*}{ Параметри } & \multicolumn{3}{|c|}{$\begin{array}{c}\text { Значајност разлика између група } 1 / \mathrm{A} \text { и } 2 / \mathrm{P} \text { - проме- } \\
\text { не регистроване током трајања студије } 0-2 \text { визита }\end{array}$} \\
\hline & 0: 1 & 0: 2 & $1: 2$ \\
\hline ЦРП (mg/L) & $p=0,665$ & $\mathrm{p}=0,903$ & $\mathrm{p}=0,532$ \\
\hline Kp (umol/l) & $\mathrm{p}=0,918$ & $\mathrm{p}=0,958$ & $\mathrm{p}=0,826$ \\
\hline УП (g/l) & $\mathrm{p}=0,155$ & $\mathrm{p}=0,818$ & $\mathrm{p}=0,717$ \\
\hline Алб (g/l) & $\mathrm{p}=0,092$ & $\mathbf{p}=0,047^{*}$ & $\mathrm{p}=0,185$ \\
\hline Хол (mmol/l) & $\mathrm{p}=0,533$ & $\mathrm{p}=0,792$ & $p=0,674$ \\
\hline Триг (mmol/l) & $p=0,462$ & $p=0,300$ & $\mathrm{p}=0,312$ \\
\hline Ц3 (g/l) & $\mathbf{p}=0,012 *$ & $\mathbf{p}=0,019 *$ & $p=0,958$ \\
\hline Ц4 (g/l) & $p=0,056$ & $\mathbf{p}=0,003^{* *}$ & $\mathrm{p}=0,07$ \\
\hline анти дс ДНА Ат IU/ml & $\mathrm{p}=0,003 * *$ & $\mathbf{p}=\mathbf{0 , 0 0 0} * * *$ & $\mathrm{p}=0,000^{* * *}$ \\
\hline ГФР/МДРД (ml/min) & $p=0,468$ & $\mathrm{p}=0,467$ & $\mathrm{p}=0,831$ \\
\hline КККр (ml/min) & $\mathrm{p}=0,506$ & $\mathrm{p}=0,901$ & $\mathrm{p}=0,591$ \\
\hline $\begin{array}{l}\text { Протеинурија по Биурету } \\
\text { (g/24h) }\end{array}$ & $\mathbf{p}=0,007^{* *}$ & $\mathbf{p}=0,000^{* * *}$ & $\mathrm{p}=0,01^{* *}$ \\
\hline Уринарни прот/креат. Уп/кре & $\mathrm{p}=0,000^{* * *}$ & $\mathbf{p}=0,000^{* * *}$ & $\mathrm{p}=0,002^{* *}$ \\
\hline СЛЕДАИ/p & $\mathrm{p}=0,927$ & $\mathrm{p}=0,294$ & $\mathrm{p}=0,71$ \\
\hline НГАЛ (ng/ml) & $\mathrm{p}=0,002 * *$ & $\mathrm{p}=0,021 *$ & $p=0,16$ \\
\hline
\end{tabular}

${ }^{*} \mathrm{p}<0,05 ;{ }^{* *} \mathrm{p}<0,01 ;{ }^{* * *} \mathrm{p}<0,001$

Статистички значајне разлике између група добијене су у поређењима нулте са првом и са другом визитом за: комплемент Ц3, анти дс ДНА антитела, 24ч.протеинурију, однос У пр/кре и НГАЛ. Поређење албумина и комплемента Ц4, статистички је било значајно само између нулте и друге визите. 


\section{4. Корелације НГАЛ са одабраним лабораторијским параметрима за групу 1/A}

Табела 16 - Корелација НГАЛ са параметрима који су значајни за активност болести

\begin{tabular}{|c|c|c|c|c|c|c|c|}
\hline \multirow{2}{*}{$\begin{array}{c}\text { Параме- } \\
\text { тар x }\end{array}$} & \multirow{2}{*}{$\begin{array}{c}\text { Статистички } \\
\text { параметри }\end{array}$} & \multicolumn{6}{|c|}{ Параметар у } \\
\hline & & Албум. & Ц3 & дсДНА & Протеинур. & СЛЕДАИ/p & УП/кре \\
\hline \multirow{2}{*}{$\begin{array}{l}\text { НГАЛ } \\
\text { Визита } 0\end{array}$} & Коеф.корелац. (r) & $-0,60$ & $-0,33$ & 0,26 & 0,94 & 0,54 & 0,93 \\
\hline & Вероватноћа & $p<0,01$ & n.s. & n.s. & $p<0,001$ & $\mathrm{p}<0,05$ & $p<0,001$ \\
\hline \multirow{2}{*}{$\begin{array}{l}\text { НГАЛ } \\
\text { Визита } 1\end{array}$} & Коеф.корелац. (r) & 0,04 & 0,32 & $-0,16$ & 0,42 & $-0,06$ & 0,41 \\
\hline & Вероватноћа & n.s. & n.s. & n.s. & n.s. & n.s. & n.s. \\
\hline \multirow{2}{*}{$\begin{array}{l}\text { НГАЛ } \\
\text { Визита } 2\end{array}$} & Коеф.корелац. (r) & $-0,49$ & $-0,50$ & 0,66 & 0,82 & 0,87 & 0,76 \\
\hline & Вероватноћа & $p<0,05$ & $p<0,05$ & $\mathrm{p}<0,001$ & $p<0,001$ & $p<0,001$ & $p<0,001$ \\
\hline
\end{tabular}

Из сумарног приказа израчунатих корелација у/НГАЛ и других битних параметара који су значајни за активност болести, уочава се статистички значајна корелација већине параметара током Визите 0 и Визите 2 а потпуна одсутност повезаности параметара током Визите 1. Детаљи потврђених корелација приказани су на следећим графиконима.

\subsection{1. Корелација у/ НГАЛ са албуминима у групи 1/А по визитама}

Следећа три графикона приказују негативну корелацију НГАЛ са албуминима у две визите (тј како расте ниво албумина у серуму, ниво НГАЛ је нижи). Статистичка значајност постоји у визитама 0 и 2 : 
Графикон 28 - Корелација у/НГАЛ и албумина у серуму у визити 0 за групу $1 / \mathrm{A}$

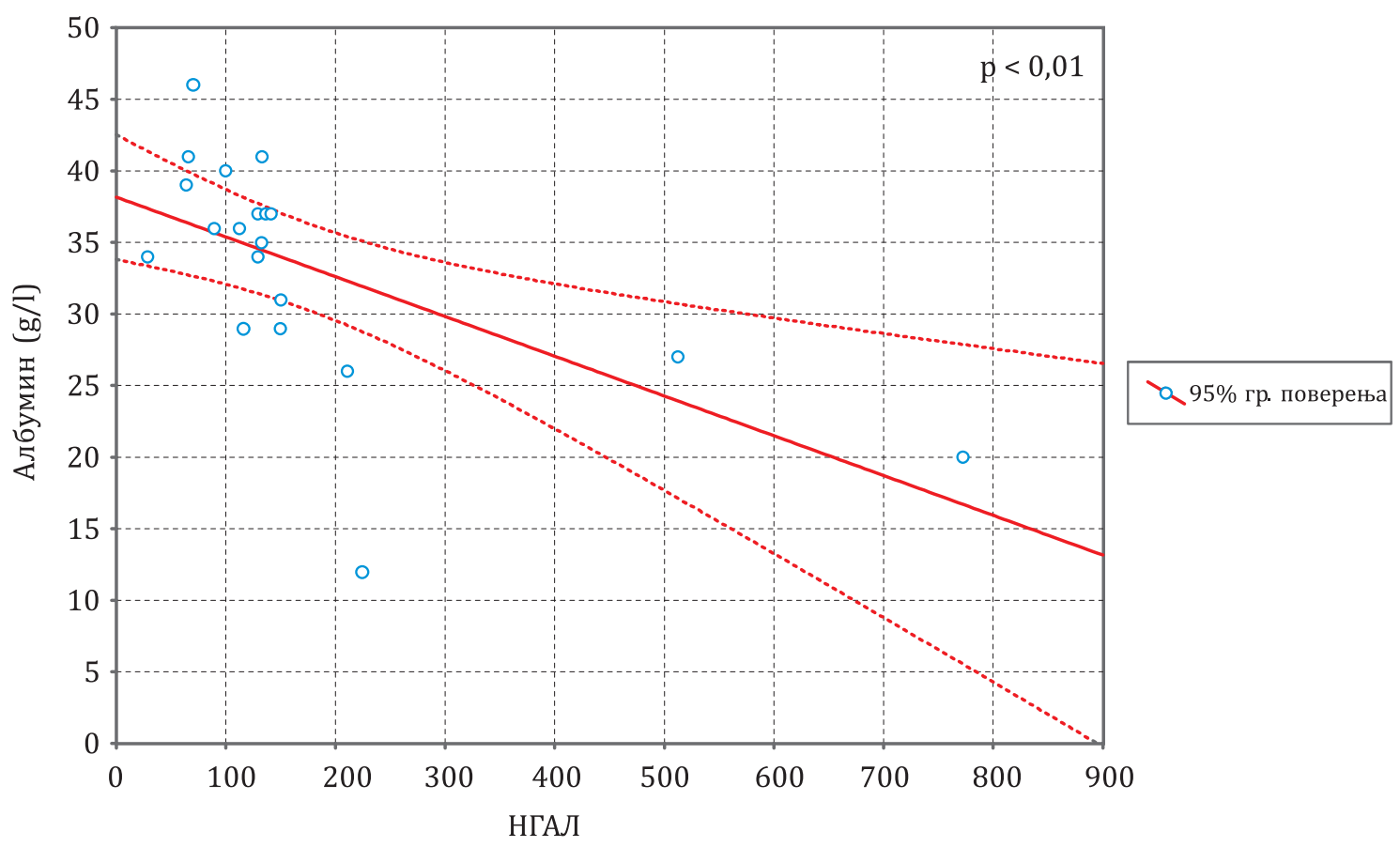

Графикон 29 - Корелација у/НГАЛ и албумина у серуму у визити 1 за групу $1 / \mathrm{A}$

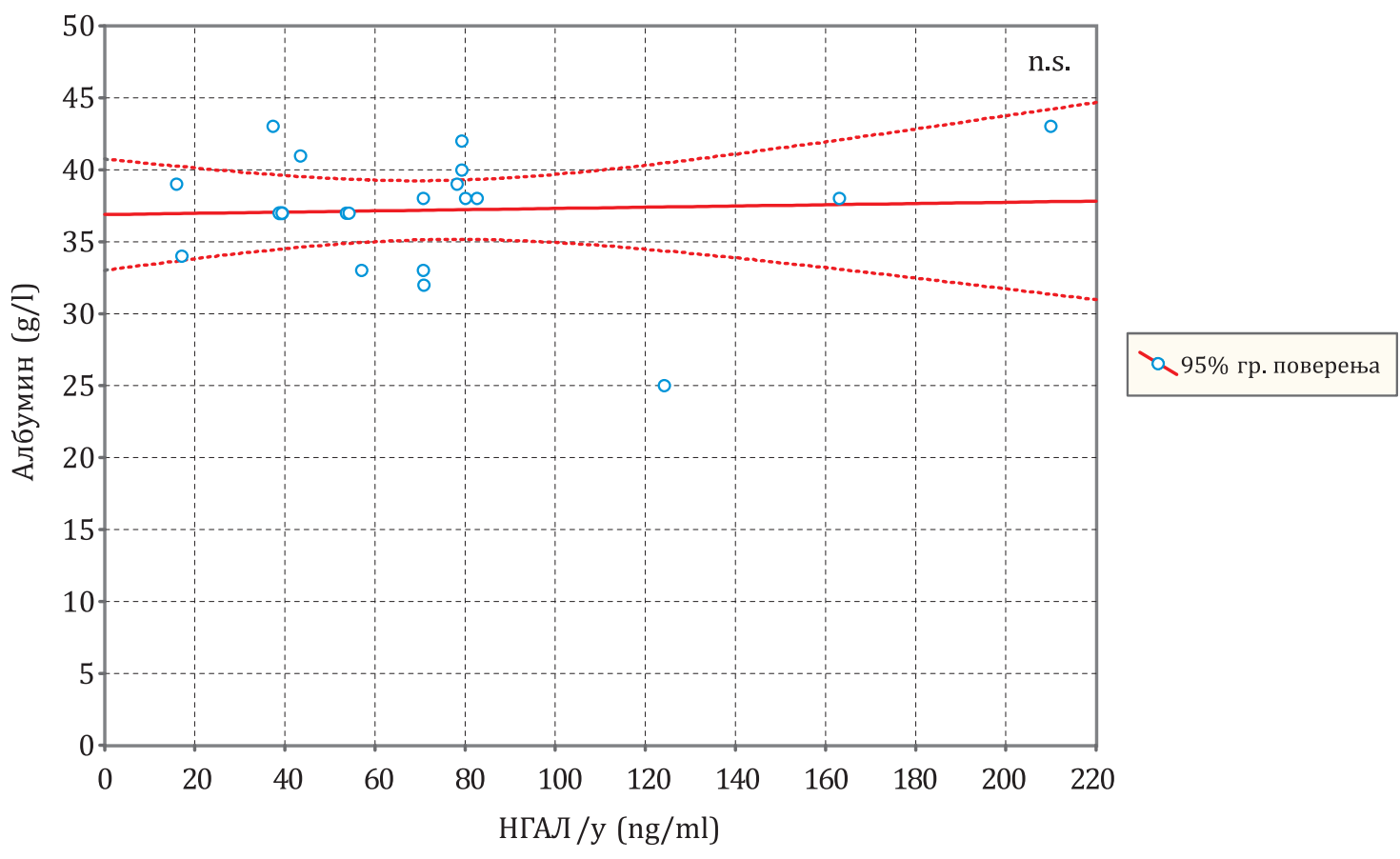


Графикон 30 - Корелација у/НГАЛ и албумина у серуму у визити 2 за групу 1/А

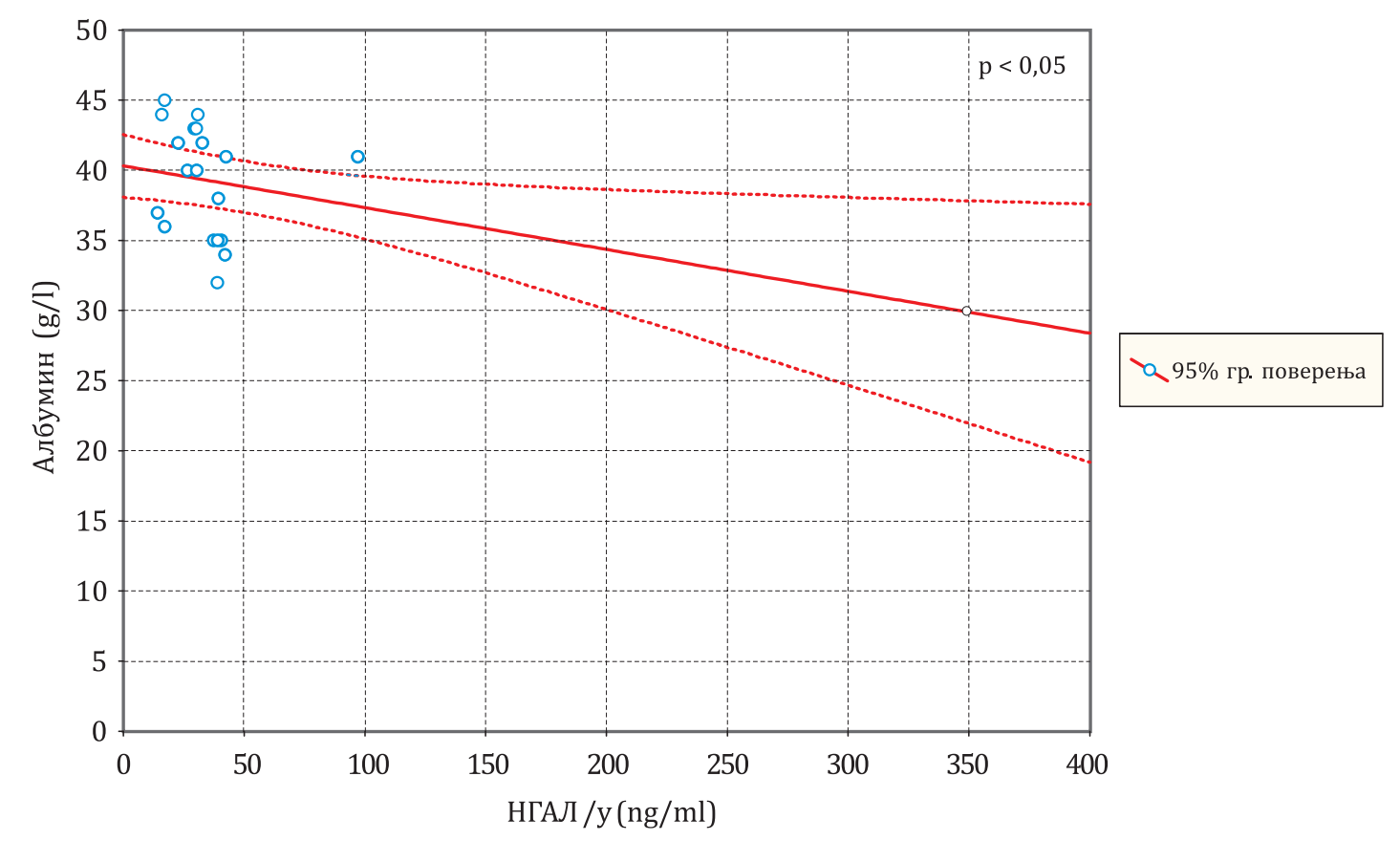

\subsection{2. Корелација у/ НГАЛ са анти дс ДНА антителима у групи 1/А по визитама}

Следећа три графикона показују позитивну корелацију дс ДНА антитела са НГАЛ у визити 2, док су остале визите статистички несигнификантне.

Графикон 31 - Корелација у/НГАЛ и анти дс ДНА Ат у визити 0 за групу 1/А

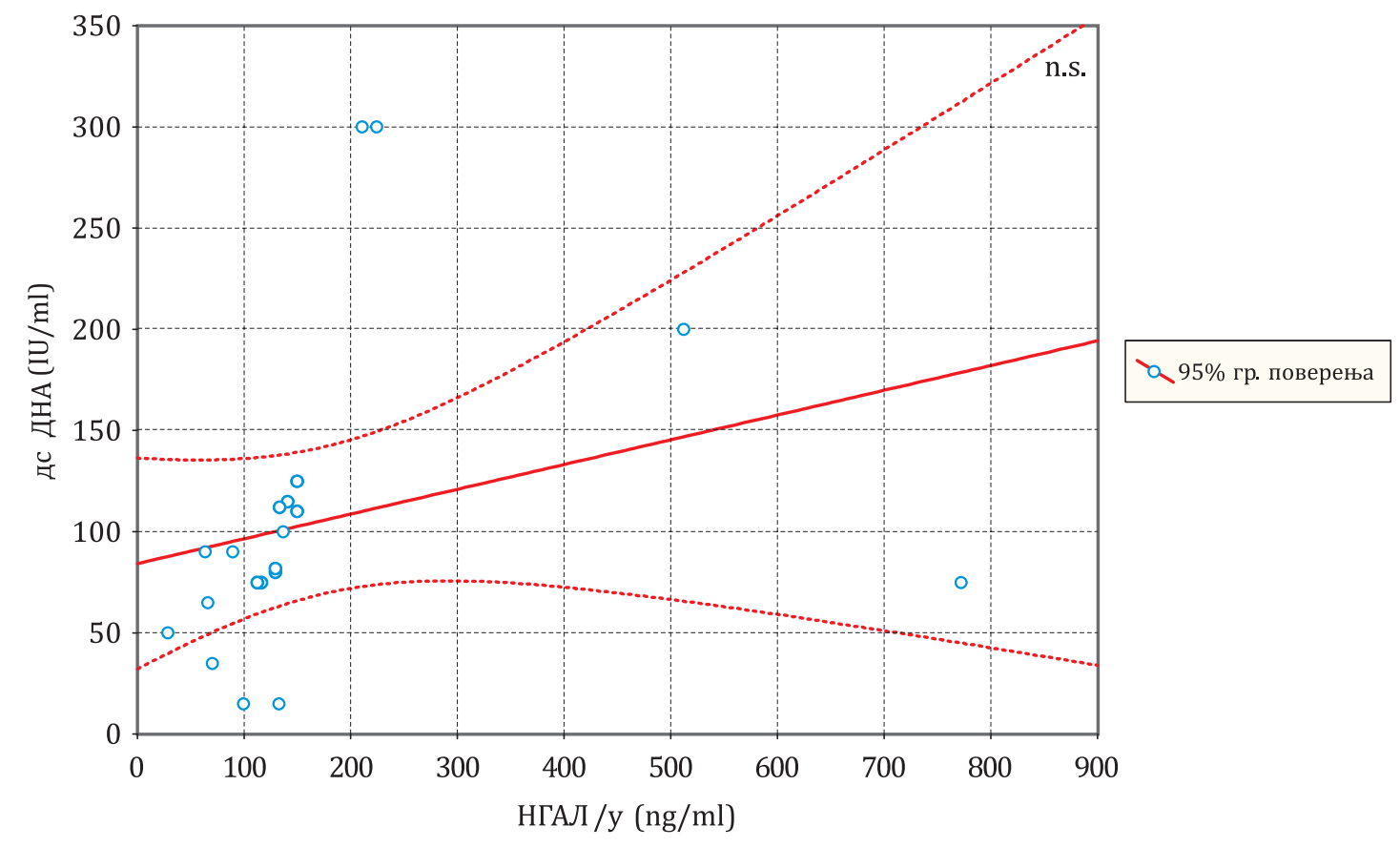


Графикон 32 - Корелација у/НГАЛ и анти дс-ДНА Ат у визити 1 за групу 1/А

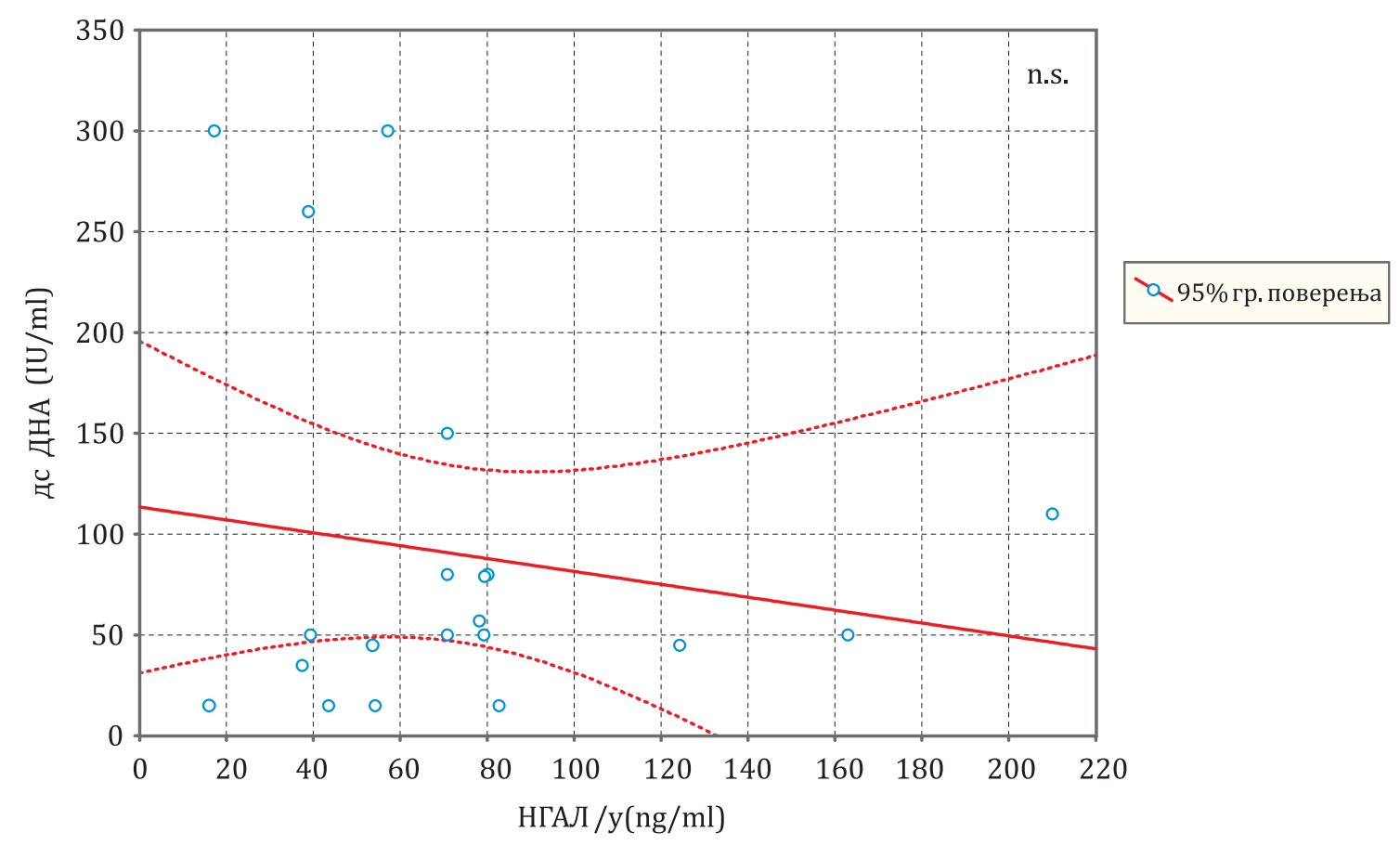

Графикон 33 - Корелација у/НГАЛ и анти дс-ДНА Ат у визити 2 за групу 1/А

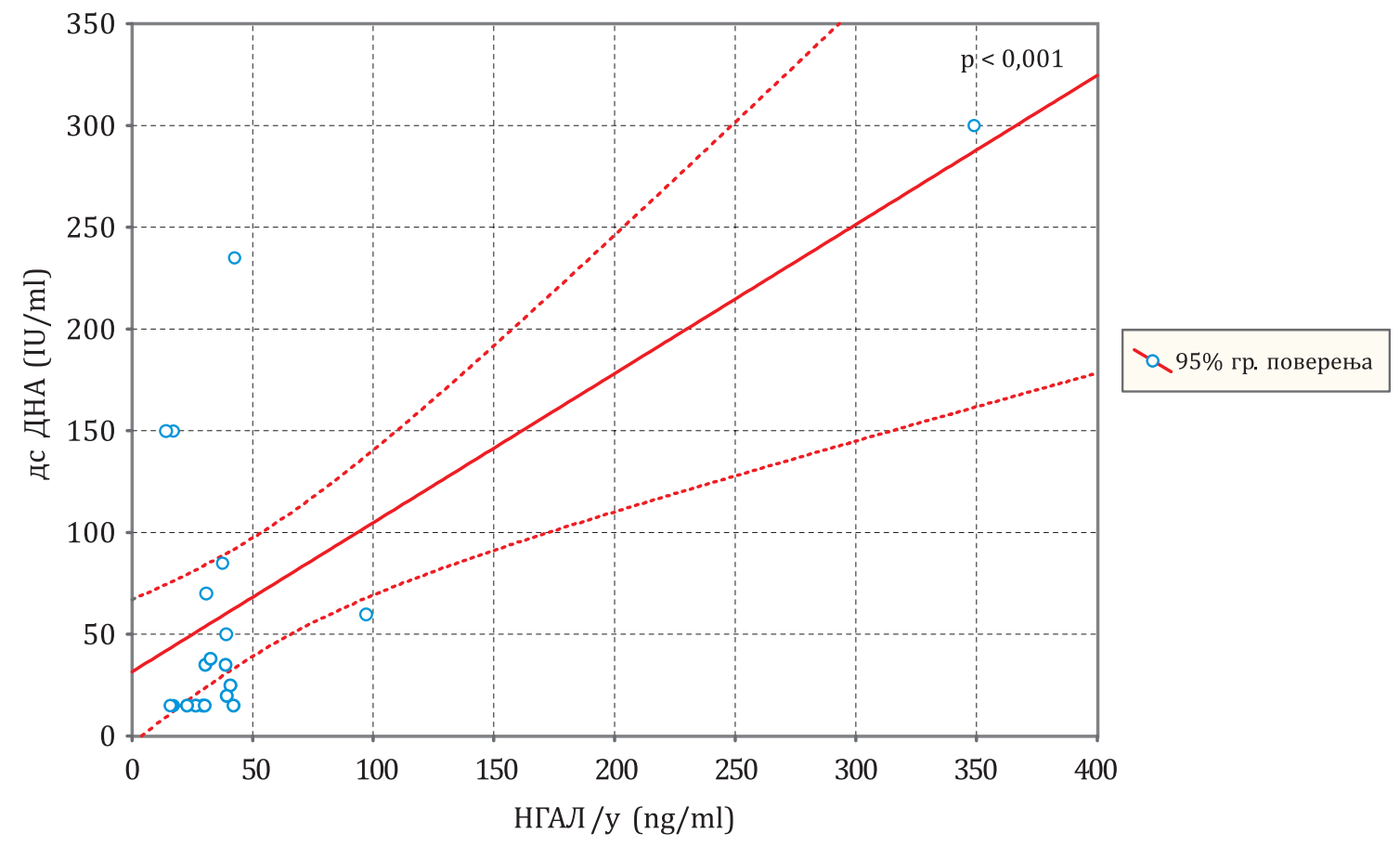




\subsection{3. Корелација у/ НГАЛ са 24ч. протеинуријом у групи 1/А по визитама}

Статистички значајна позитивна корелација између НГАЛ и 24ч. протеинурије приказана је у визити 0 и 2 :

Графикон 34 - Корелација у/НГАЛ и 24ч. протеинурије у визити 0 за групу 1/А

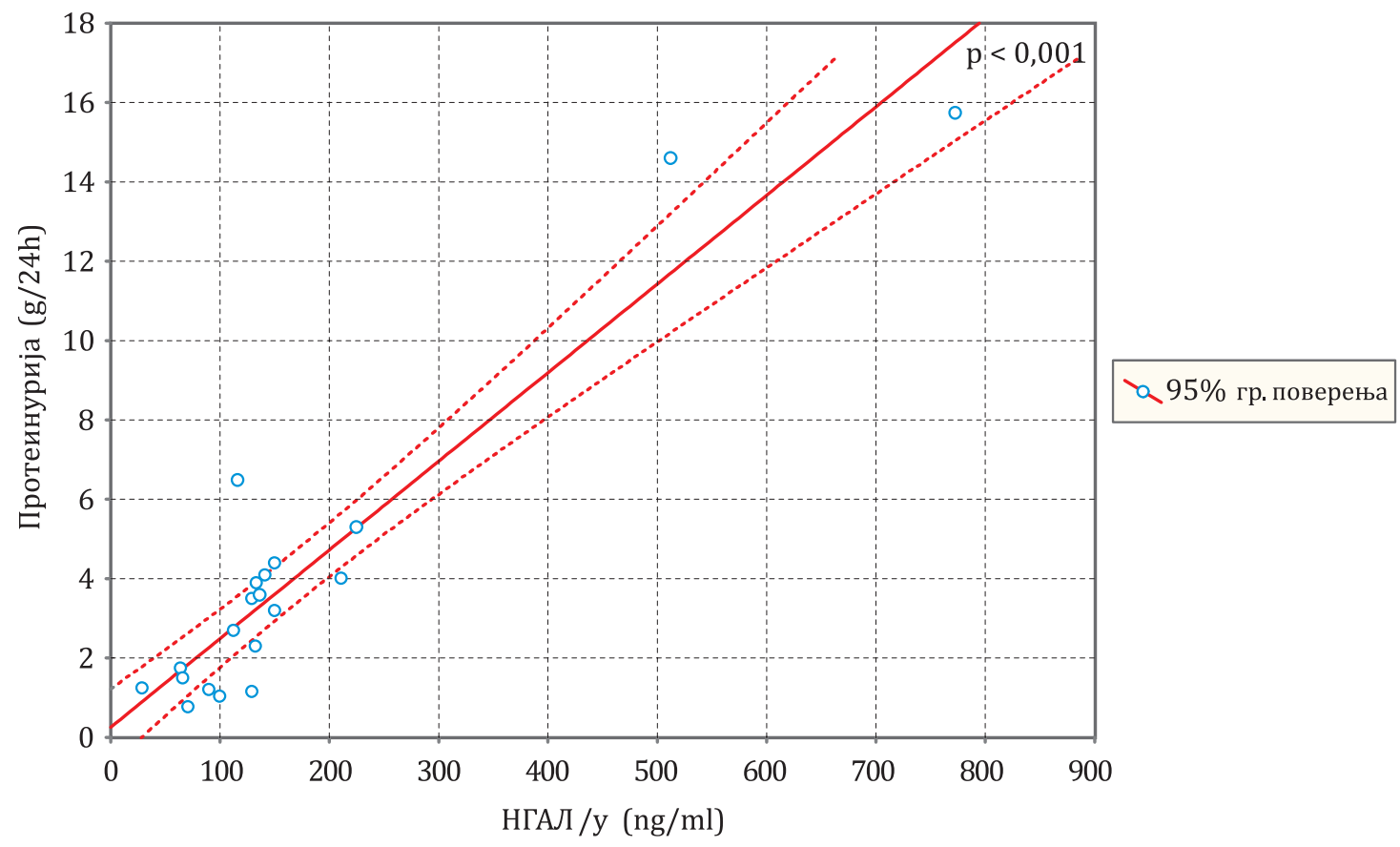

Графикон 35 - Корелација у/НГАЛ и 24ч. протеинурије у визити 1 за групу 1/А

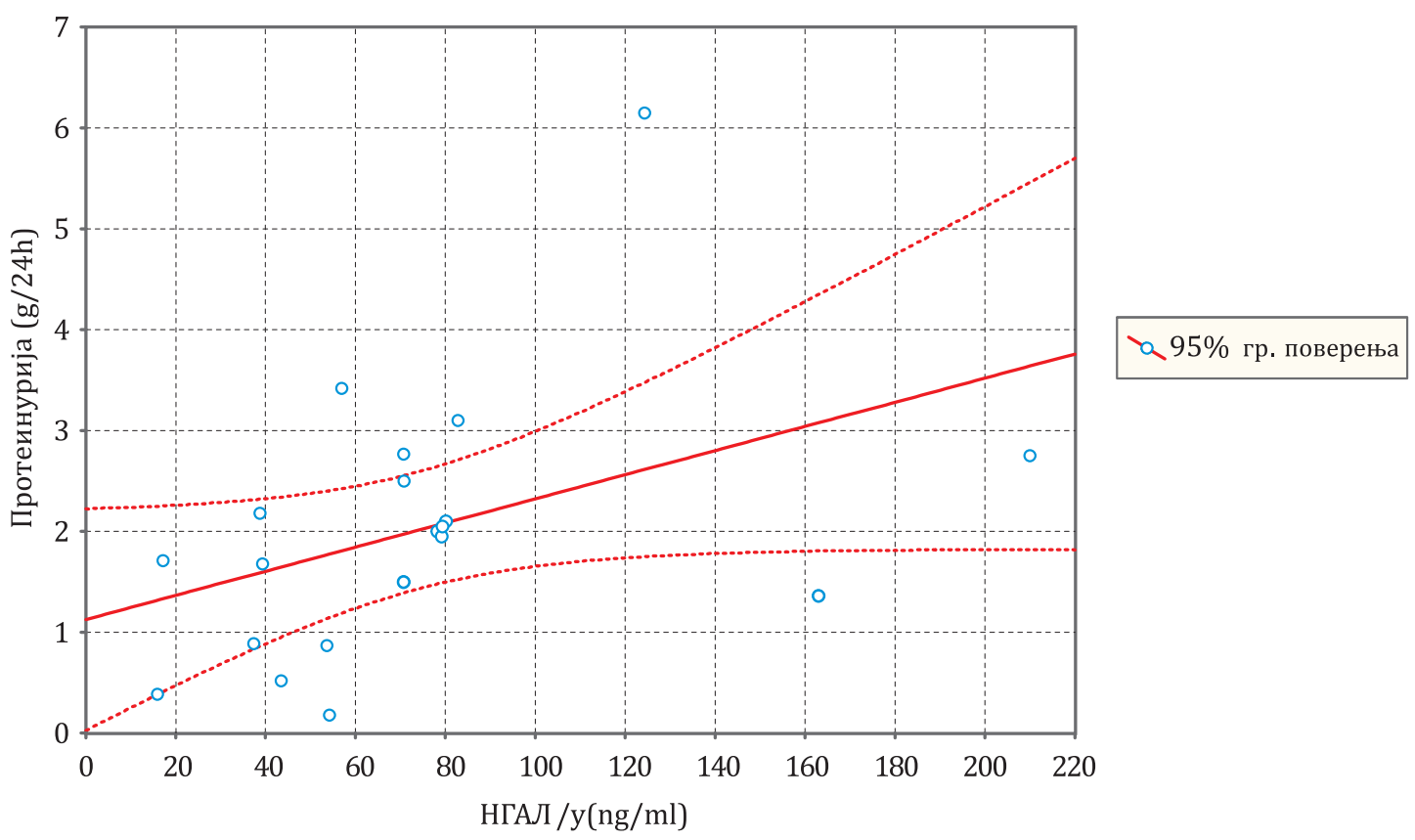


Графикон 36 - Корелација у/НГАЛ и 24ч. протеинурије у визити 2 за групу 1/А

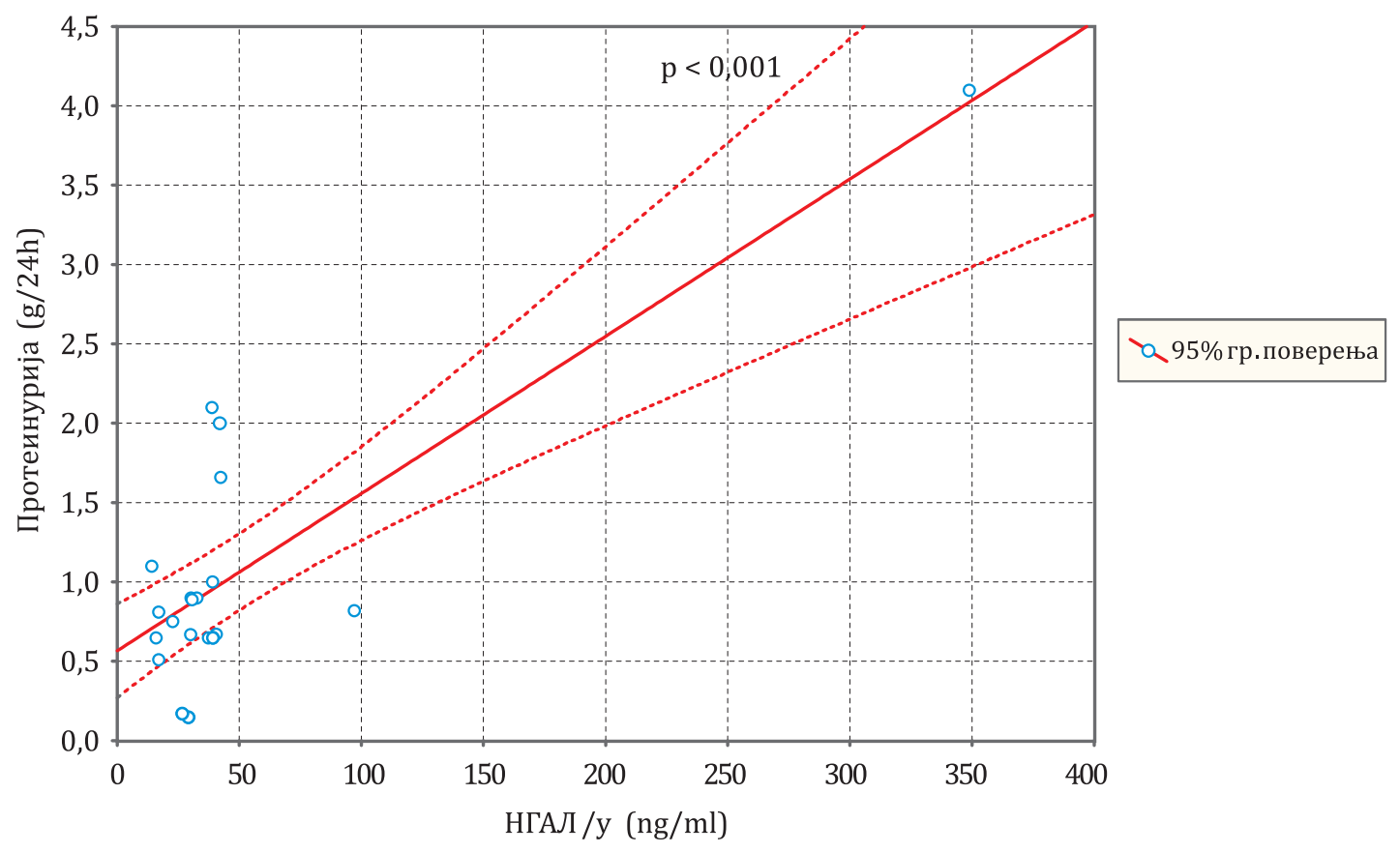

\subsection{4. Корелација у/ НГАЛ са СЛЕДАИ/р у групи 1/А по вИзИтама}

Такође се запажа статистички значајна позитивна корелација између НГАЛ и СЛЕДАИ/р у визитама 0 и 2 , док у визити 1 нема значајне разлике:

Графикон 37 - Корелација у/НГАЛ и СЛЕДАИ/р у визити 0 за групу 1/А

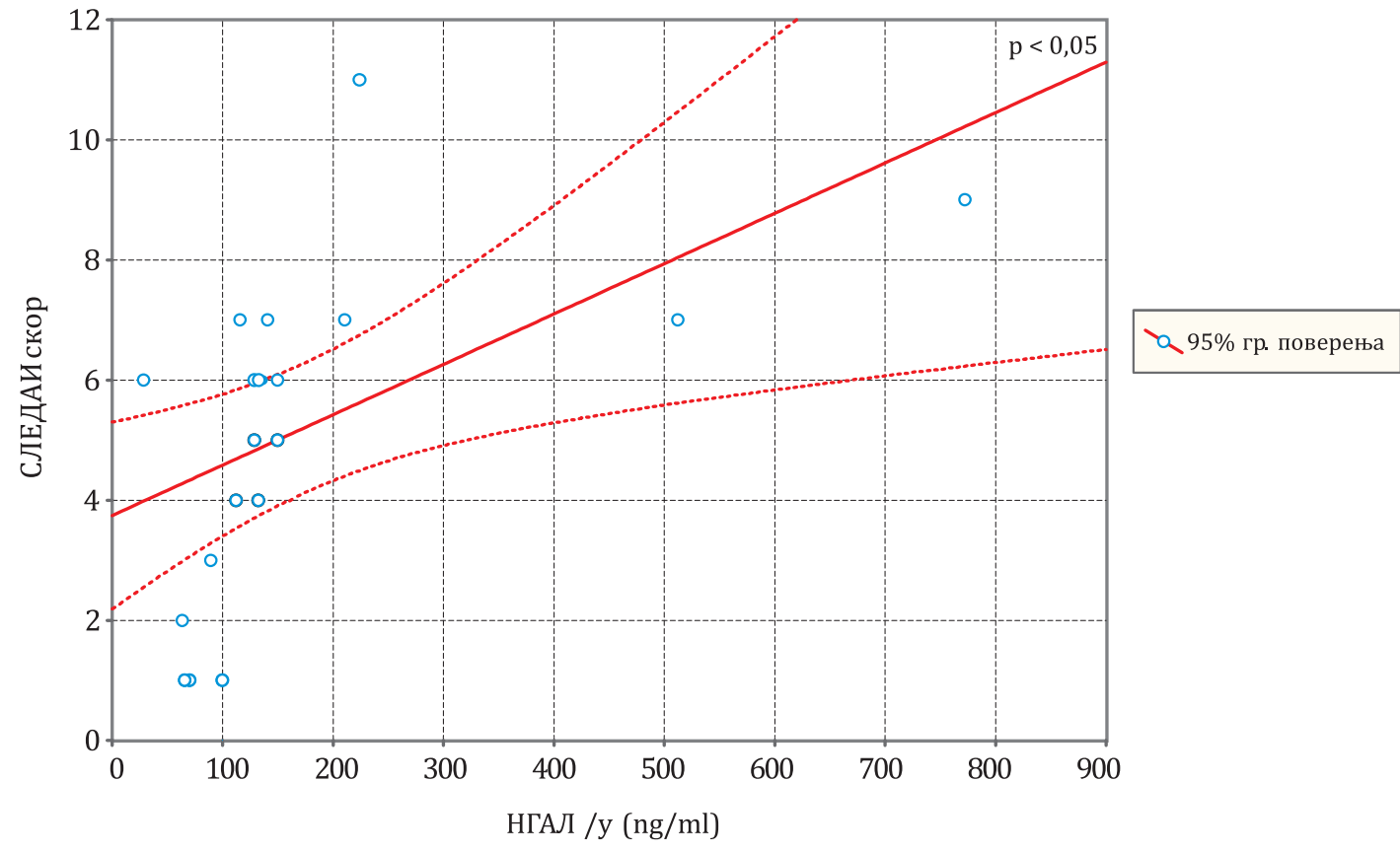


Графикон 38 - Корелација у/НГАЛ и СЛЕДАИ/р у визити 1 за групу 1/А

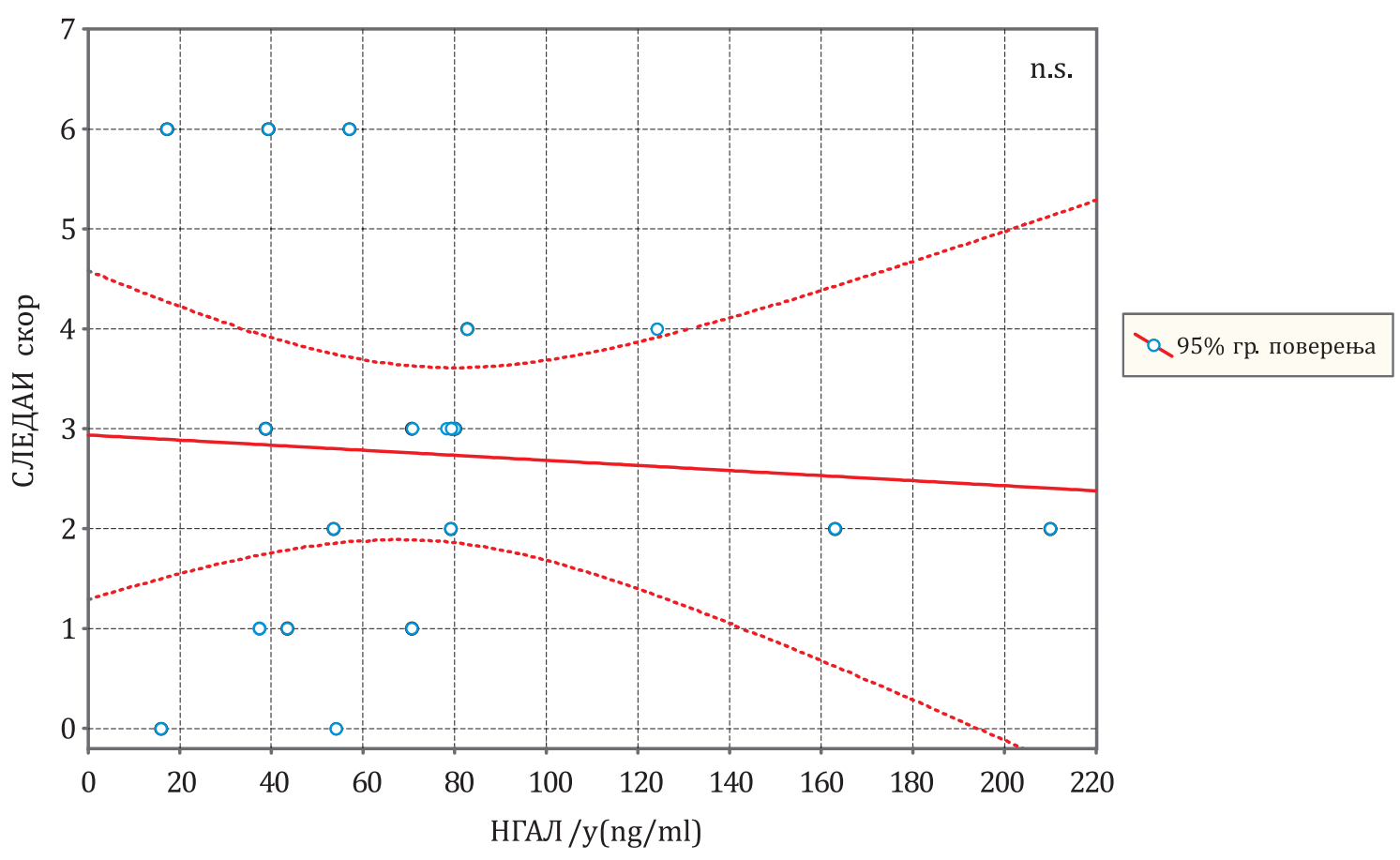

Графикон 39 - Корелација у/НГАЛ и СЛЕДАИ/р у визити 0 за групу 1/А

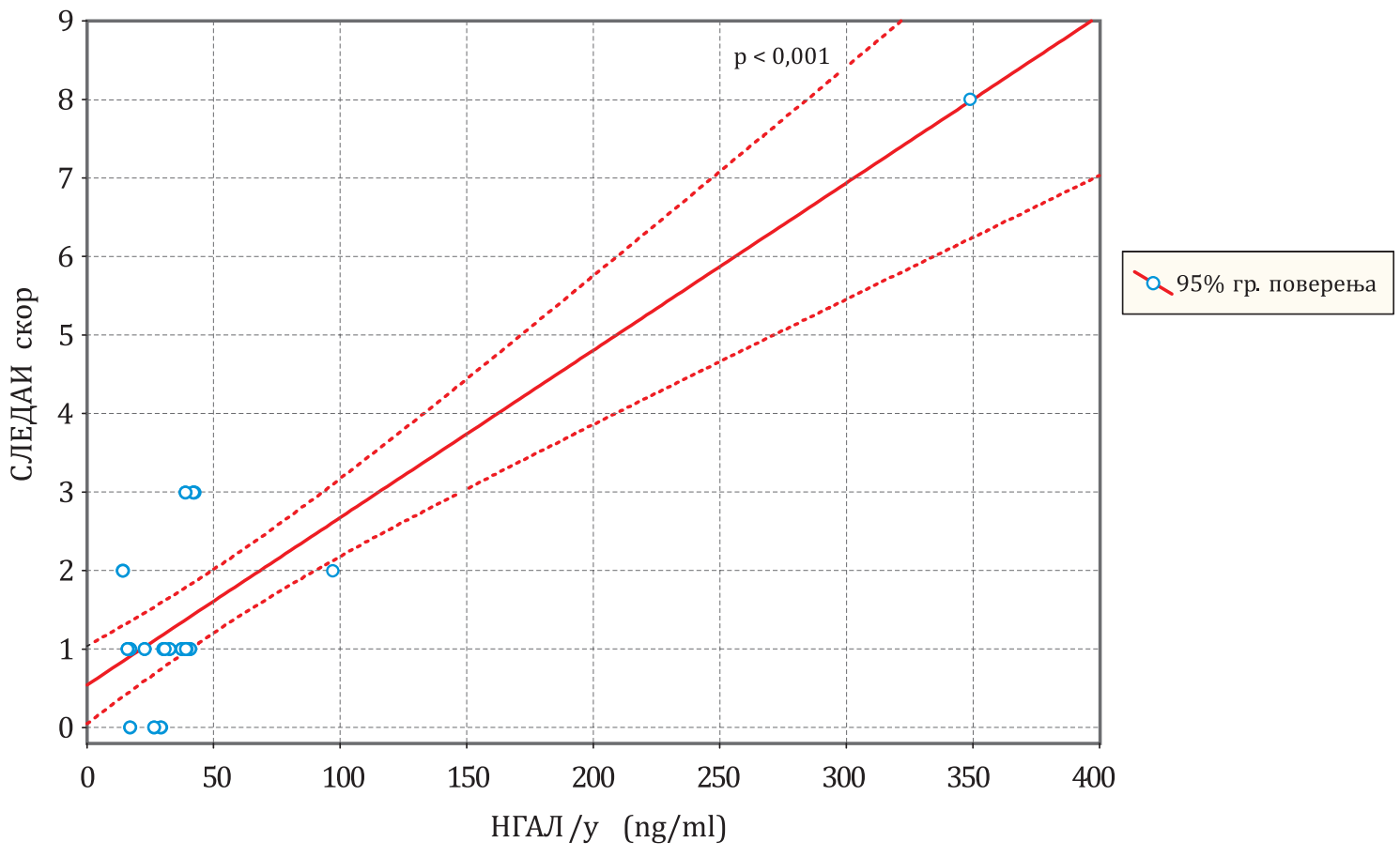




\subsection{5. Корелација у/ НГАЛ са Уп/кре у групи 1/А по визитама}

На следећим графиконима приказана је позитивна корелација између НГАЛ и УП/кре која је статистички значајна у визити 0 и 2. Смањење у односу Уп/кре корелира са смањењем НГАЛ .

Графикон 40 - Корелација у/НГАЛ и УП/кре у визити 0 за групу 1/А

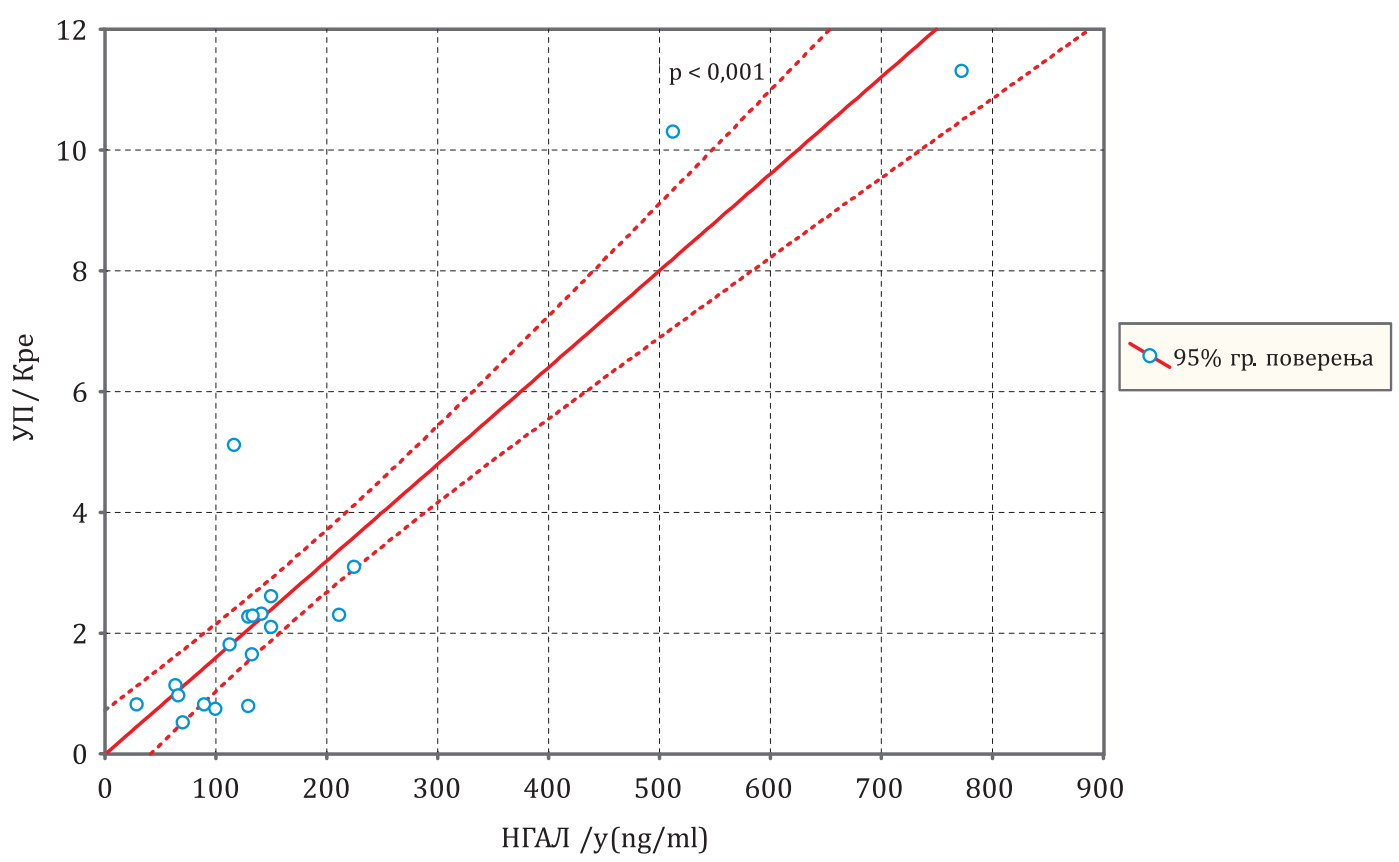

Графикон 41 - Корелација у/НГАЛ и УП/кре у визити 1 за групу 1/А

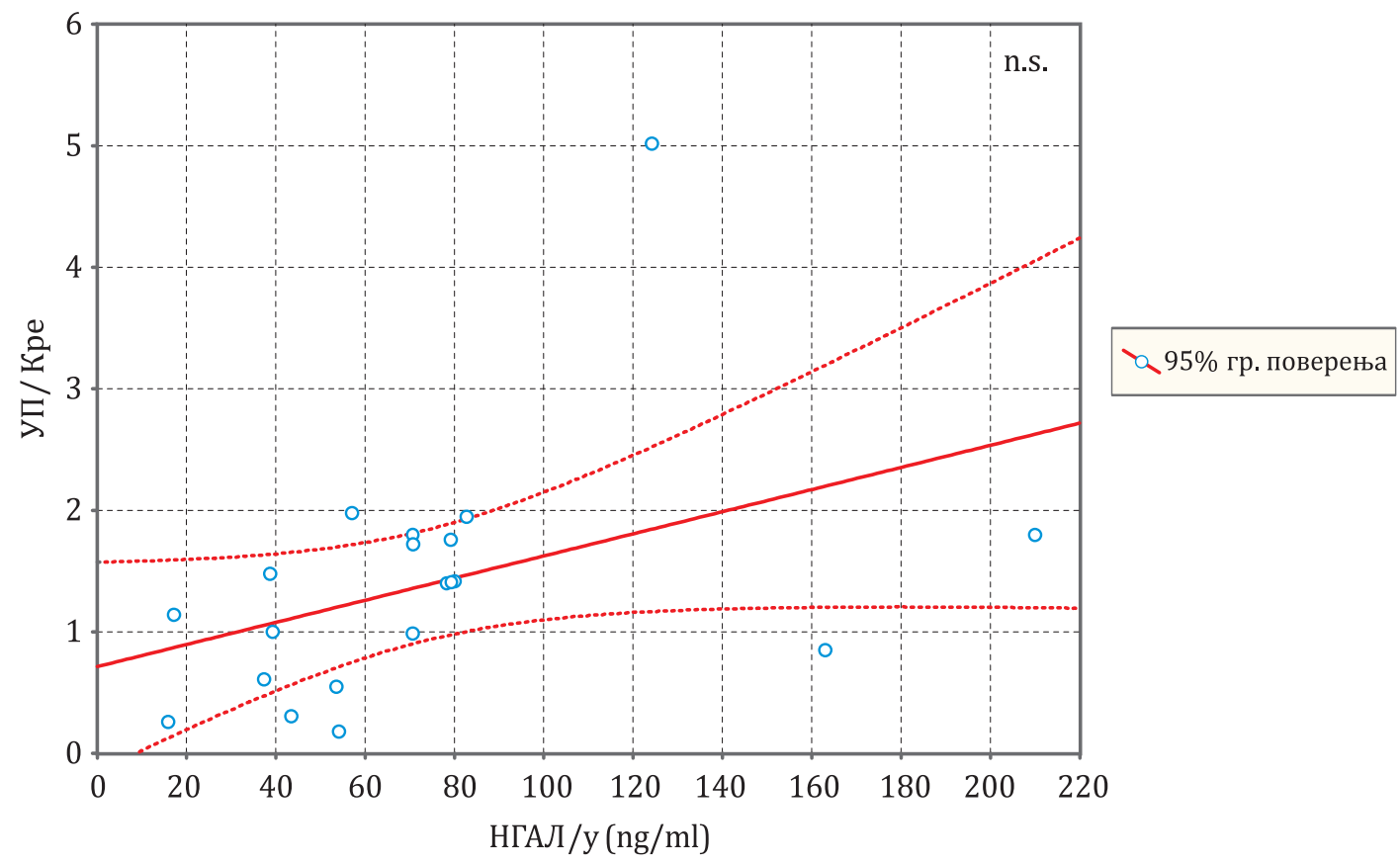


Графикон 42 -Корелација у/НГАЛ и Уп/кре у визити 2 за групу 1/А

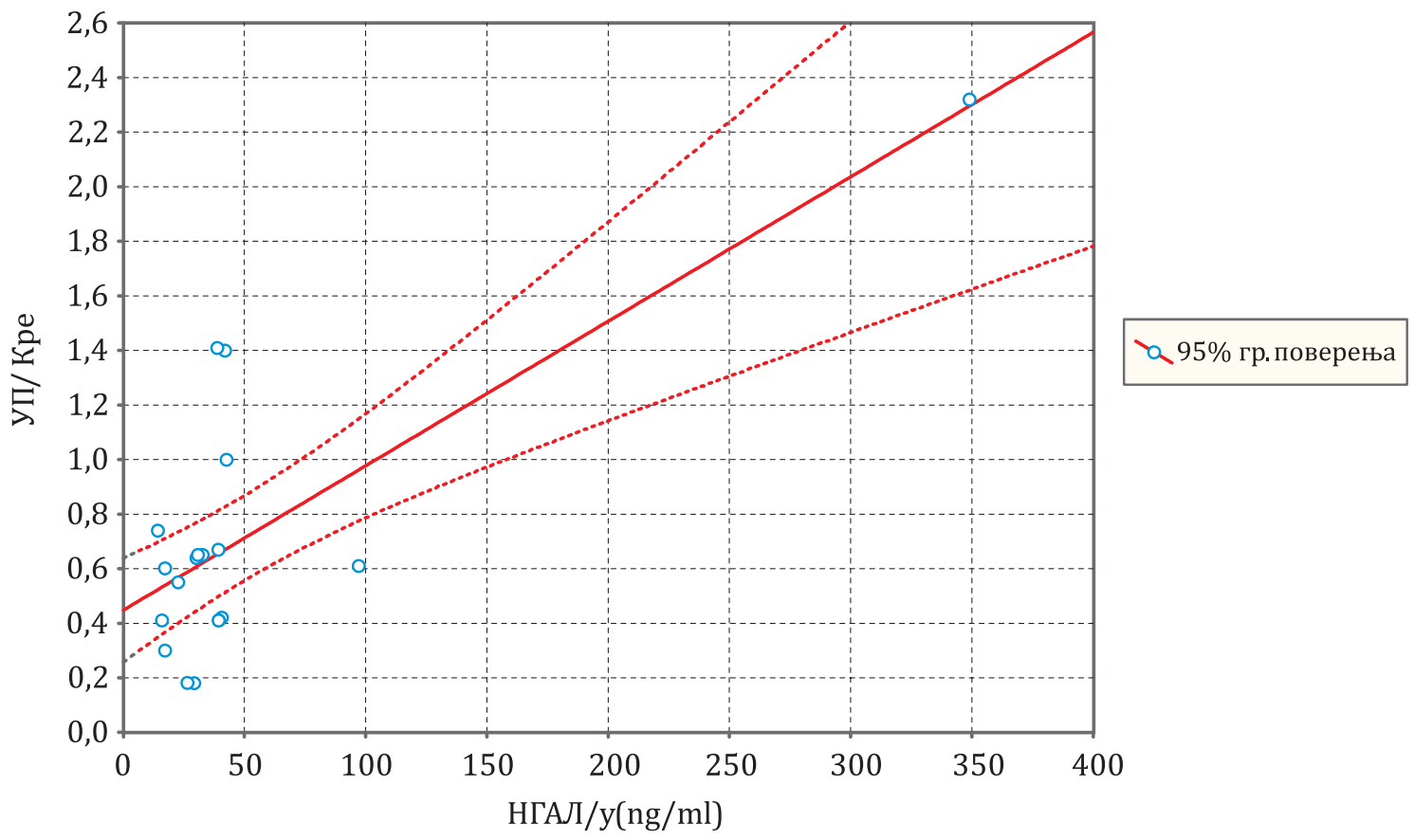

На основу претходних резултата конструисана је ROC крива за одабране параметре: НГАЛ 0, протеинурију 0, СЛЕДАИ/р 0, УП/кре 0, дс-ДНА Ат 0, и АНА 0 са граничним вредностима за специфичност и сензитивност:

Табела 17 - Координате криве за параметре:

НГАЛ 0, протеинурију 0, СЛЕДАИ/р 0, УП/кре 0, дс ДНА 0, АНА 0,

\begin{tabular}{|c|c|c|c|c|c|}
\hline \multicolumn{6}{|c|}{ Координате криве } \\
\hline \multirow{2}{*}{$\begin{array}{c}\text { Резултат } \\
\text { (варијабле) }\end{array}$} & \multirow{2}{*}{ Површина } & \multirow{2}{*}{$\begin{array}{l}\text { Станд. } \\
\text { Грешка }\end{array}$} & \multirow{2}{*}{ Сигнификан. } & \multicolumn{2}{|c|}{ Интервал вероватноће (95\% ) } \\
\hline & & & & Доња граница & Горња граница \\
\hline НГАЛ 0 & 0,995 & 0,007 & 0,00 & 0,0 & 1,000 \\
\hline Протеинурија0 & 0,983 & 0,016 & 0,00 & 0,0 & 1,000 \\
\hline СЛЕДАИ/р 0 & 0,977 & 0,018 & 0,00 & 0,0 & 1,000 \\
\hline УП/кре 0 & 0,983 & 0,016 & 0,00 & 0,0 & 1,000 \\
\hline дс ДНА 0 & 0,904 & 0,052 & 0,00 & 0,796 & 1,000 \\
\hline AHA 0 & 0,873 & 0,058 & 0,00 & 0,758 & 0,987 \\
\hline
\end{tabular}


Графикон 43 - ROC крива за одабране параметре

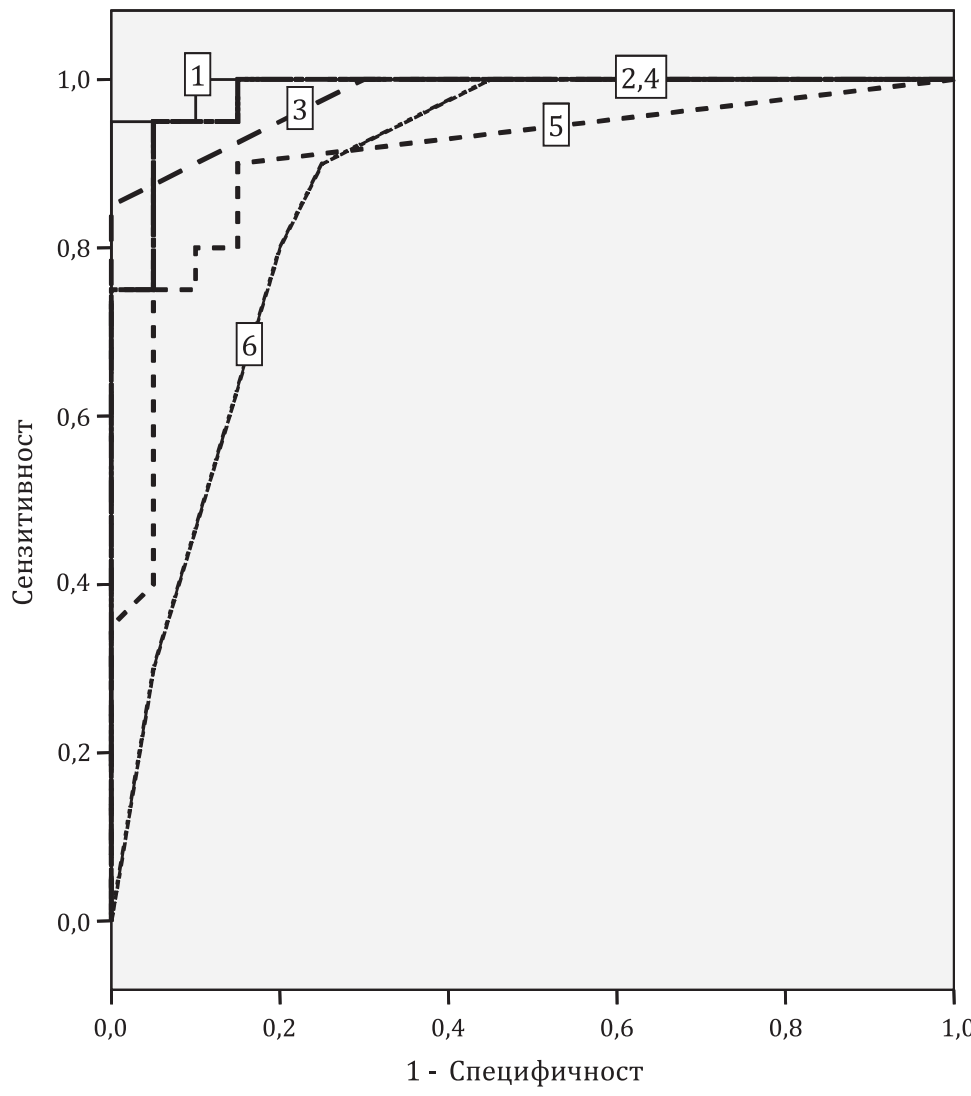

Легенда

— НГАЛ (1)

— Протеинурија (2)

- - СЛЕДАИ/p (3)

- Уп//кре (4)

- - дс ДНА(5)

- AHA (6)

На основу вредности површине испод криве (AUC) највећу сензитивност уз прихватљиву специфичност испољава у/НГАЛ. Крајње десно на ROC криви су АНА антитела која су најмање сензитивна.

Табела 18 - Координате криве: резултат варијабле за НГАЛ 0

\begin{tabular}{|c|c|c|}
\hline НГАЛ $\mathrm{ng} / \mathrm{ml}$. & Сензитивност & 1- Специфичност \\
\hline 22,6000 & 1,000 & 0,250 \\
\hline 24,9500 & 1,000 & 0,200 \\
\hline 27,2500 & 1,000 & 0,150 \\
\hline 28,0000 & 1,000 & 0,100 \\
\hline 35,1500 & 0,950 & 0,100 \\
\hline 42,0500 & 0,950 & 0,050 \\
\hline $\mathbf{5 2 , 9 5 0 0}$ & $\mathbf{0 , 9 5 0}$ & $\mathbf{0 , 0 0 0}$ \\
\hline 64,7500 & 0,900 & 0,000 \\
\hline 68,0000 & 0,850 & 0,000 \\
\hline 79,8000 & 0,800 & 0,000 \\
\hline 94,5000 & 0,750 & 0,000 \\
\hline 105,9000 & 0,700 & 0,000 \\
\hline 114,5000 & 0,650 & 0,000 \\
\hline
\end{tabular}


У Табели 18, дат је сегмент теоретских вредности у/НГАЛ и одговарајућих вредности сензитивности и специфичности. Тамно назначеним словима приказан је ред који представља оптималну граничну вредност (енгл. „cut off” ) вредност за у/НГАЛ.

Према координатама на ROC криви за у/НГАЛ, гранична вредност је $52,95 \mathrm{ng} / \mathrm{ml}$.

При тој вредности сензитивност је 95\%, а специфичност је 100\%.

Сви пацијенти са у/НГАЛ више од $52,95 \mathrm{ng} / \mathrm{ml}$, треба да буду у групи $1 / \mathrm{A}$, а ниједан у групи 2/P. 
5. ДИСКУСИЈА 
Савремени трендови у нефрологији усмерени су ка истраживањима дијагностичких метода високе сензитивности и специфичности које су у исто време једноставне, неагресивне и брзе. Лупус нефритис, као једна од најтежих компликација СЛЕ која се јавља у око 27-66\% болесника, карактерише се развојем бубрежних промена које за кратко време могу постати иреверзибилне (126). Међутим и поред значајног помака у дијагностици и лечењу ЛН, $10-26 \%$ болесника ће за 10 година, развити терминалну фазу бубрежне инсуфицијенције $(127,128)$. Истраживања на пољу уринарних биомаркера за активност болести су посебно драгоцена. Уринарни НГАЛ је биомаркер са већ доказаним значајем у раној дијагностици акутне бубрежне инсуфицијенције различите етиологије (контрастна нефропатија, утицај нефротоксичних лекова, сепса, исхемијско-реперфузијски поремећаји). Његова могућа улога у дијагностици осталих бубрежних обољења још увек није довољно истражена.

Веома је мало објављених студија које су истраживале улогу у/НГАЛ у дијагностици и у праћењу резултата лечења ЛН. Прве студије које су објављене, биле су у дечијој популацији $(124,129-133)$. То није било случајно, јер група педијатријских болесника са СЛЕ је свакако најосетљивија не само због тежине болести и могућности за настанак трајног оштећења бубрега, већ и због потребе да се допуни стандардна лабораторијска дијагностика која је данас недовољно инструктивна. Уринарни биомаркери глобално представљају потенцијални дијагностички избор број један посебно за ову популацију. Биопсија бубрега која нам пружа непроцењиве податке о типу ЛН и степену активности и хроницитета, у дечијем узрасту није популарна метода. И ако је у адултној популацији биопсија бубрега честа, добијени пато-хистолошки налази служе само као орјентација у датом временском периоду када је учињена. Серијске биопсије нису метод којим би могли на једноставан начин да пратимо ток болести, успех лечења, мењамо терапију и индивидуализујемо модалитет лечења. То су били разлози због којих је последњих неколико година учињено пар студија у педијатријској популацији са врло афирмативним почетним резултатима у коришћењу у/НГАЛ у СЛЕ и ЛН.

Већина ових истраживча је користила ЕЛИСА комерцијалне китове за одређивање у/НГАЛ, који су мање сензитивни у поређењу са ЦМИА имунохемијским тестовима - који користе хемилуминесцент имуноесеј технологију са антителима високог афинитеа према епитопима за НГАЛ. Ову новију методу која је потврђена у студији од 196 болесника након оперативне кардиопулмо- 
налне реваскуларизавије, а корелира са ЕЛИСА тестовима, користили смо у нашој студији (132).

Прве студије у педијатрији поредиле су ниво у/НГАЛ између болесника са ЛН (доказаним биопсијом бубрега) и идиопатским јувенилним артритисом (ИЈА), као и унутар саме групе СЛЕ болесника $(128,129)$. То су биле углавном студије пресека у којима је запажено да на ниво у/НГАЛ нису утицале године старости, пол, телесна тежина, висина, раса $(128,129)$.

У нашој студији проспективног карактера поређене су две групе болесника са ЛН које су биле хомогене (без статистички значајне разлике по полу, годинама и телесној тежини) а праћене су у временском периоду од 4 месеца.

Корелација НГАЛ са серумским креатинином потврђена је у бројним студијама у којима су испитивани болесници са акутном бубрежном инсуфицијенцијом најразличитије етиологије (80-114). Исто тако постоје студије које указују и да хронично бубрежно оштећење утиче на ниво у/НГАЛ (102, 115-121).

Корелација серумског креатинина тј. степена бубрежне слабости са нивоом с/НГАЛ била је предмет педијатријске студије у којој је учествовало 45-оро деце са хроничном бубрежном инсуфицијенцијом ранга од 2-4 степена (60-15 мил/мин). Проспективним праћењем серумског креатинина, цистатина Ц, ГФР, запажено је да с/НГАЛ корелира са цистатином Ц (р < 0.000) као и да с/НГАЛ и цистатин Ц сигнификантно корелирају са ГФР ( $<<0.000)$, поготово када је ГФР $\geq 30 \mathrm{ml} / \mathrm{mi}$. Ипак и поред закључка да с/НГАЛ корелира и са ГФР и цистатином Ц, запажена је нешто боља корелација измеу с/НГАД и ГФР (132).

То је потврђено и код болесника са израженом реналном активношћу СЛЕ. Код њих повишени ниво НГАЛ и у серуму и у урину, корелира са серумским креатинином и степеном бубрежне функције $(124,125,133,134)$.

Имајући овај податак у виду, водили смо рачуна да ни један од наших болесника нема клиренс креатинина мањи од 60 мл/мин, иницијално тј. у нултој визити. На тај начин избегли смо утицај хроничне лезије бубрега на ниво у/НГАЛ односно могућност да ниво НГАЛ у урину не буде репрезентативан за активност ЛН.

Пратећи наше болеснике у наредним визитама у групи са активном болешћу нисмо имали акутни пораст креатинина односно развој бубрежне инсуфицијенције, а вредности креатинина и клиренса креатинина у групи I/A између визита, као и између група, нису биле статистички значајно раз- 
личите. На тај начин искључен је НГАЛ као параметр акутне бубрежне инсуфицијенције. Његове промене током визита могле су једино бити условљене активношћу лупус нефритиса.

У групи болесника код којих је ЛН био у ремисији, током праћења болест је била стабилна, односно није запажено акутно погоршање параметара бубрежне функције након иницијалне визите.

У студији Brunnera i sar. запажен је значајно виши ниво у/НГАЛ код болесника са ЛН (35 болесника) односу на групу са ИЈА (8 болесника), као и корелација између у/НГАЛ и индекса активности бубрежног оштећења у СЛЕ (129). Такође регистрована је и корелација у/НГАЛ и Уп/ кре, а није запажена корелацијау/НГАЛ-а са екстрареналним индексом активности СЛЕ (129). Ниво у/НГАЛ је био статистички значајно различит $(p<0.0001)$ у групи болесника са СЛЕ и ЛН који су имали активну лезију (17 болесника) поредећи са групом без активне лезије бубрега (18 болесника). Ниво НГАЛ од > 0.6 ng/mg стандардизован према уринарном креатинину је 90\% сензитиван и 100\% специфичан за СЛЕ са ЛН у дечијој популацији (129).

У нашој групи болесника са активним ЛН, која је праћена у 3 визите (20 болесника), ниво уринарног НГАЛ је био повишен и износио је 173,25 $\pm 172,12$ $\mathrm{ng} / \mathrm{ml}$ у 0 визити, а у визити 2 до 49,60 $272,57 \mathrm{ng} / \mathrm{ml}$. У групи са ЛН у ремисији, био је нижи и износио је 18,75 $\pm 10,76 \mathrm{ng} / \mathrm{ml}$ у 0 визити, а у визити 2 био је $13,35 \pm 10,22 \mathrm{ng} / \mathrm{ml}$.

Ниво у/НГАЛ код наших болесника корелирао је са активношћу болести, а поређењем између група, као што је и очекивано, био је статистички значајно виши у свим визитама $(\mathrm{p}<0,001)$ у групи $(1 / \mathrm{A})$ у којој је болест била активна.

Описујући однос између индекса активности болести израженог преко СЛЕДАИ и у/НГАЛ у студији Brunnera i sar. запажена је корелација у/НГАЛ-а са индексом реналне активности СЛЕДАИ/p ( $<0.0005)$, али не и за у/НГАЛ и екстраренални индекс активности СЛЕ (128). Ниво у/НГАЛ такође је корелирао и са односом Уп/кре ( $<$ 0.05) (129).

У нашој студији добијена је статистички значајна корелација $(\mathrm{p}<0,001)$, у/НГАЛ и СЛЕДАИ/р у групи болесника са активним ЛН у поређењу са контролном групом код које је тај однос несигнификантан. Имајући у виду да је наша студија била проспективна, у групи са активним ЛН ниво у/НГАЛ у другој визити био је значајно нижи, али је и даље је корелирао са СЛЕДАИ/р индексом што се објашњава повољним почетним ефектом лечења, али и 
потребом за наставком индукционе терапије. Довољно дугим праћењем било би очекивано да када индекс реналне активности буде 0 , ниво у/НГАЛа буде на нивоу у/НГАЛ у контролној групи. То би било значајно за болеснике код којих би тада дозе лекова могле да буду на нивоу доза које користимо у одржавању стабилне ремисије ЛН. Слично је и са другим параметрима које смо пратили у урину, запажена је значајна корелација у/НГАЛ са протеинуријом и са односом УП/кре $(\mathrm{p}<0,001)$.

У педијатриској студији Suzuki-ja i sar. која је испитивала 85 болесника са ЛН поређени су у/НГАЛ и с/НГАЛ. Утврђено је да у/НГАЛ корелира са индексом активности реналне лезије, док то није запажено код с/НГАЛ-а. Посебно је ниво у/НГАЛ био виши у групи са дифузним пролиферативним типом ЛН у поређењу са мембранским ЛН (130).

Сви наши болесници са ЛН имали су IV тип, а група са активном болешћу имала је и веома високе нивое у/НГАЛ. То се подудара са запажањима неких аутора да је ниво у/НГАЛ виши у пролиферативним формама ЛН. То су закључили поредећи тип III са типом II ЛН и описујући сигнификантно виши ниво у/НГАЛ у групи са типом IV ЛН, у односу на групу са типом V ЛН $(130,131)$. Постоје и аутори који сматрају да на ниво у/ НГАЛ нема утицаја пато-хистолишки тип ЛН (129).

У студији Нinza и сарадника која је обухватила 111 педијатријских болесника са СЛЕ активност болести мерена је стандардним индексима и поређена са нивоом у/НГАЛ и с/НГАЛ (124). Запажено је да ниво у/НГАЛ порасте за 104\%, 3 месеца пре погоршања болести, док је с/НГАЛ такође сигнификантно повишен у оквиру глобалног погоршања СЛЕ за 20\% три месеца пре осталих параметара, а за 26\% 3 месеца пре уоченог погоршања ЛН. Запажено је да су оба нивоа НГАЛ и у урину и у серуму повишена и значајни су предиктори погоршања и активности ЛН код деце $(124,125)$.

Ми нисмо пратили болеснике по започењању терапије па до постизања ремисије. Међутим наши резултати у групи 1/А показују да су у/НГАЛ и СЛЕДАИ/р први показатељи смиривања активности болести под терапијом у односу на протеинурију и Упр/кре (Табела 12).

Сигурно је, да ће бити потребне нове студије болесника са ЛН које ће потврдити резултате Hinza i sar. да је у/НГАЛ најранији параметар активности и смиривања болести код болесника са ЛН. Ови резултати подвлаче значај рутинског одређивања у/НГАЛ код болесника са ЛН. 
Yang i sar. су закључили да је у/НГАЛ много бољи као биомаркер бубрежног оштећења у СЛЕ од IL-10, TGF- $\beta 1$ и TNF- $\alpha$ (134). Испитивањем су показали да је TGF- $\beta 1$ and TNF- $\alpha$, у урину виши код болесника са CЛЕ, али и код других аутоимуних болести, а да је у/НГАЛ висок само код СЛЕ болесника са ЛН (испитивана је група од болесника који су имали СЛЕ, затим 24 бол. са СЛЕ и ЛН и контролна група са болесницима који су имали не - СЛЕ аутоимуне болести. За њих је изненађење био податак да је IL-10 у урину био несигнификантно различит у свим овим групама. Према њиховој студији ниво у/НГАЛ је сигнификантно виши код болесника са СЛЕ који имају нефритис и у позитивној је корелацији са нивоом креатинина у серуму ( $\mathrm{p}=0.010)$, а негативно корелира са клиренсом креатинина $(\mathrm{p}=0.023)$. Такође су закључили да је у/НГАЛ високо сензитиван и специфичан и да је бољи предиктор у дијагностици бубрежног оштећења од анти дс-ДНА антитела (134). То су потврдили формирањем ROC криве за у/НГАЛ: сензитивност 0.755 (р=0.033; 95\% CI, 0.587-0.924) према анти дс-ДНА антителима 0.600 (p=0.416; 95\% CI, 0.336-0.864). Имајући у виду да нема сигнификантне корелације са Ц3, Ц4, СЛЕДАИ, сматрали су да је висок ниво у/НГАЛ-а у групи СЛЕ са бубрежним оштећењем директна последица лезије бубрега, а не активне имунолошке реакције у бубрегу (134).

Пратећи и поредећи биохемијске и имунске анализе (ук. протине, албумине, комплемент Ц3 и Ц4) код наших болесника статистички значајна разлика је добијена између група само у почетним визитама што их сврстава у параметре са малом сензитивнишћу и специфичношћу.

Сличне податке запазили су и Brunner i sar., анализирајући групу од 35 болесника, добили су унутар ROC криве сензитивност 0,944, специфичност 1, а ниједан од параметра праћења (укључујући хематурију, протеинурију, комплемент, анти дс- ДНА антитела, однос У пр/кре, СЛЕДАИ/р скор), није имао компарабилно високу сензитивност и специфичност код болесника са ЛН (потврђеним биопсијом) (129).

И наша студија је такође, показала сличне резултате које смо добили анализирајући сензитивност и специфичност у/НГАЛ у групи болесника са СЛЕ и активним ЛН (нешто виши резултат) и поредећи га са нивоом анти дс- ДНА антитела. У групи са активним ЛН, добијена је ROC крива и "cutoff" вредност за у/НГАЛ од 52,95 ng/mg. Код наших болесника са активним ЛН у/ НГАЛ је имао сензитивност од 0.95 и специфичност од 1,0. Поље унутар ROC криве за у/НГАЛ износило је 0,995, а ниједан други параметар за активност болести 
(СЛЕДАИ/р, УП/кре, протеинурија, дс ДНА, АНА, није имао такву сензитивност и специфичност.

У/НГАЛ је показао већу сензитивност и специфичност и у нашој студији, као и у претходним, а пратећи болеснике са активним ЛН у следећим контролама запажа се да је у/НГАЛ параметар који много раније постиже ниже вредности, што је у складу са осталим параметрима за активност ЛН, као што су СЛЕДАИ/р, 24ч. протеинурија, однос Уп/кре. У другој визити запажа се да анти дс-ДНА антитела и даље перзистирају у високом титру $(67,90 \pm 80,37)$, док су остали параметри активности већ у нивоима који означавају скору ремисију ЛН.

За разлику од студије Yang i sar. у којој није добијена статистички значајна корелација у/НГАЛ са 24ч. протеинуријуом, СЛЕДАИ/р и односом Уп/ кре код нас је забележена (134). Мишљења смо да је на разлику утицао тип ЛН, jep су наши болесници имали IV тип ЛН, док се у студији Yang i sar, jacно не дефинише тип ЛН, обзиром да није учињена биопсија бубрега код свих болесника. Активност болести је мерена искључиво преко СЛЕДАИ/р индекса са критеријумом да протеинурија буде већа од 0,5 g/24h. У нашој групи болесника средња вредност протеинурије износила је 4,12 4 ,08 g/24h, док је у овој студији просечна протеинурија била нижа, износила је 2,82 g/24h. Сами аутори подвлаче овај недостатак студије.

За разлику од њих у групи од 70 адултних болесника са СЛЕ од којих су 32 имала активну болест Pitashny i sar. су уочили да је ниво у/НГАЛ значајно виши у групи са бубрежном лезијом у поређењу са контролном коју су чинили СЛЕ болесници без ЛН и здраве особе, али и да је статистички значајна корелација са индексом активности СЛЕДАИ/р, а што је утврђено и у другим студијама као и у нашој (135-137). Ови аутори су потврдили исто што и остали да ниво у/НГАЛ не корелира са екстрареналним манифестацијама $(133,137)$.

Значајна је такође и студија Rubinstein T i sar. која управо подвлачи да је праћење анти дс-ДНА антитела као маркера за активност болести, много мање сензитивно од у/НГАЛ који свакако има своје место у спектру лабораторијских анализа код болесника са ЛН (138). Њихова студија упућује на већу осетљивост и специфичност овог биомаркера у односу на друге показатеље активности ЛН и сходно томе потребу за рутинским одређивањем у скоријој будућности.

Анализирајући наше резултате у којима је у/НГАЛ, показао високу осетљивост и специфичност за активност болести, посебно у поређењу са 
анализама које су у рутинској употреби, закључили смо да његово увођење у свакодневну праксу, може бити значајан допринос у дијагностици, лечењу и праћењу болесника са ЛН.

Иницијалним одређивањем у/НГАЛ као и у даљим контролама много брже би предвидели и пратили активност болести. Тиме би благовремено могли утицати на промену терапијских протокола и на тај начин на прогнозу и исход ЛН. Приметили смо да је СД за у/НГАЛ веома велика код наших болесника, односно да су појединачни нивои у/НГАЛ у зависности од степена активности болести били од $173,25 \pm 172,12 \mathrm{ng} / \mathrm{ml} \mathrm{у} 0$ визити до 49,60 $\pm 72,57 \mathrm{ng} / \mathrm{ml}$ у 2 визити то потврђује да постоје индивидуалне разлике међу болесницима.

То намеће закључак да би већ на самом почетку испитивања и лечења ЛН код сваког болесника, било значајно одредити ниво у/НГАЛ, који би био неопходан за даље праћење болесника. Ниво у/НГАЛ може утицати на модалитет имуносупресивне терапије и на дужину трајања индукционе терапије. Имајући у виду да је у нашој студији добијена и гранична вредност за активност болести- ниво у/НГАЛ од 52,95 ng/ml., серијским одређивањем би лечење ових тешких болесника било олакшано. Према нашој студији вредност у/НГАЛа од $52,95 \mathrm{ng} / \mathrm{ml}$., била би карактеристика болесника са ЛН у ремисији. Међутим то подразумева и потребу за новим студијама са већим бројем болесника и дужим праћењем, које би потврдиле наше резултате.

На основу наших резултата мишљења смо да је у/НГАЛ биомаркер који ће врло брзо наћи примену у дијагностици, лечењу и праћењу болесника са ЛН. 
6. ЗАКЉУЧЦИ 
- Студија је обухватила болеснике са СЛЕ и ЛН тип IV, од којих је 20 имало активну болест а 20 болест која је била у ремисији, а према јасним параметрима за активност болести. На почетку периода праћења бележи се статистички значајна разлика између група у следећим лабораторијским параметрима:

а) у серуму: ук протини, албумини, Ц3, Ц4, анти дс - ДНА антитела.

б) у урину: СЛЕДАИ/р, протеинурија 24ч, Уп/кре, НГАЛ.

- У току даљег праћења у првој и другој визити, запажа се статистички значајна разлика између група, само у уринарним параметрима, све време $(\mathrm{p}<0,001)$. Скоро сви параметри у серуму у групи са активним ЛН, се на примењено лечење нормализују, осим анти дс ДНА антитела, која остају повишена на нивоу статистичке значајности која се смањује са $\mathrm{p}<0,001$ на почетку праћења на $\mathrm{p}<0,01$ у другој визити.

- Појединачним приказом по групама запажају се у групи 1/А много веће вредности за 24ч. протеинурију, СЛЕДАИ/р, УП/кре, у/НГАЛ, а праћењем тих болесника појединачно, вредности се код већине постепено смањују, мада се запажају и болесници код којих се ниво ових параметра одржава и изискује наставак агресивнијег лечења. У групи 2/Р ти исти параметри су много нижи и углавном су у референтним границама током студије. Средња вредност у/НГАЛ у 2/Р групи болесника поређењем у три визите статистички је незначајна, што је у складу са осталим параметрима активности болести. Наравно ниво у/НГАЛ је значајно нижи у односу на групу 1/А. То потврђује претпоставку да ниво у/НГАЛ поређен са осталим параметрима корелира са степеном активности болести. Највиши ниво су имали управо болесници са највећом протеинуријом, Уп/кре и СЛЕДАИ/р индексом.

- Поређењем значајности разлика између група 1/А и 2/Р (промене регистроване током трајања студије 0-2 визита) добијена је статистичка значајност за протеинурију, Уп/кре, док је за СЛЕДАИ/р и у/ НГАЛ у визити 2 та значајност статистички несигнификантна. Овакав налаз може се објаснити чињеницом да је примењено лечење довело до значајаног опоравка бубрежног оштећења које се манифестовало побољшањем у налазу седимента урина и тубулске функције бубрега манифестоване преко у/НГАЛ.

- Поређењем значајности разлика између група, а пратећи ниво анти дс ДНА антитела и у/НГАЛ, запажа се много спорија нормализација вредности анти дс- ДНА антитела од у/НГАЛ. То потврђује претпоставку да је у/НГАЛ 
параметар који корелира са активном болешћу, много сензитивније од анти дс- ДНА антитела.

- Анализом добијених података потврђена је статистички сигнификантна корелација између нивоа у/НГАЛ и параметара активне болести и то за:

а) у серуму: албумине - негативна корелација која је статистички значајна,

Ц3 - позитивна корелација која је статистички значајна и анти дс ДНА - позитивна корелација која је статистички значајна

б) у урину: СЛЕДАИ/p - позитивна корелација статистички значајна, Уп/кре - позитивна корелација статистички значајна и 24ч. протеинурију позитивна корелација која је статистички значајна.

- На основу добијених анализа формирањем РОК криве, запажен је у/ НГАЛ као најсензитивнији показатељ активности болести, а АНА као најслабија.

- Према координатама на РОК криви за у/ НГАЛ, гранична вредност је $52,95 \mathrm{ng} / \mathrm{ml}$. При тој вредности сензитивност је 95\%, а специфичност је 100\%. Сви пацијенти са у/НГАЛ већим од $52,95 \mathrm{ng} / \mathrm{ml}$ треба да буду у групи $1 /$ А то јест то би била гранична вредност за активну болест.

Ни један болесник који има болест у ремисији не би требао да има НГАЛ већи од 52,95 ng/ml. Ово потврђује да је у/ НГАЛ сензитивнији показатељ активности ЛН поредећи га са стандардним лабораторијским и имунским параметрима

- Корелација у/НГАЛ и тежине клиничке слике представља сензитиван прогностички параметар у току лечења, односно указује на велики значај у/ НГАЛ а у праћењу активности болести и праћењу резултата лечења.

- Рутинским коришћењем тестова за одређивање уринарног биомаркера НГАЛ код болесника са ЛН смањује се потреба за понављаним биопсијама бубрега у евалуацији ефекта лечења.

- Серијско праћење у/НГАЛ код болесника са ЛН, има предност у свакодневној пракси. Током лечења ЛН а уз серијско праћење у/НГАЛ лекари имају могућност за оптимизацију лечења и благовремену промену модалитета у лечењу што је прогностички значајно. 
- Индивидуално праћење нивоа у/НГАЛ код болесника са ЛН омогућава бољу стратегију у дужини примене одређених терапијских протокола, што утиче на смањење кумулативне дозе лекова и мањи токсични ефекат терапије, посебно код млађих болесника. 
7. ЛИТЕРАТУРА 
1. Pisetsky DS, Buyon JP, Manzi S. Chapter 17. Systemic lupus erythematosus. In: Klippel JH, Crofford LJ, Stone JH, Weyand CM. Primer on the Rheumatic Diseases. Edition 12. Arthritis Foundation, Atlanta, GA., 2001.

2. Rus V, Hajeer A, Hochberg MC. Chapter 7. Systemic lupus erythematosus. In: Silman AJ, Hochberg MC (eds.) Epidemiology of the Rheumatic Disease. 2nd edition. Oxford University Press, New York, 2001.

3. Blotzer JW. A history of systemic lupus erythematosus. http://www.lupus.org.nz/history.php

4. Hochberg MC.The history of lupus erythematosu. Md Med J 1991; 40 (10): 871-3.

5. Lahita RG. Introduction. In: Lahita RG, ed. Systemic Lupus Erythematosus. New York: John Wiley and Sons. 1987; 1-3.

6. Boltzer JW. Systemic lupus erythematosus. I. Historical aspects. MD State Med J 1983; 37:439.

7. Wagner L. Immunosupressive agents in lupus nephritis: A critical analysis. Medicine, 1976; 55: 239-50

8. Isenberg DA, Snaith ML, Morrow WJ et al. Cyclosporin A for the treatment of systemic lupus erythematosus. Int J Immunopharmacol 1981;3:163-9.

9. Halloran PF, Cole EH, Bookman AA, Urowitz MB, Clarke WTW. Possible beneficial effect of ciclosporin in some cases of severe systemic lupus erythematosus. In: Schindler R, ed. Cyclosporin in autoimmune diseases. Berlin: Springer, 1985:356-60.

10. Miescher PA, Favre H, Chatelanat F, Mihatsch MJ. Combined steroid-cyclosporin treatment of chronic autoimmune diseases. Clinical results and assessment of nephrotoxicity by renal biopsy. Klin Wochenschr. 1987;65(15):727-36.

11. Duddridge M, Powell R J. Treatment of severe and difficult cases of systemic lupus erythematosus with tacrolimus. A report of three cases. Ann Rheum Dis 1997;56:690-92.

12. Chan TM, Li FK, Tang CSO, Wong RWS, Fang GX, et al. Efficacy of Mycophenolate Mofetil in Patients with Diffuse Proliferative Lupus Nephritis. N Engl J Med 2000; 343:11561162.

13. Anolik JH, Campbell D, Felgar R, Rosenblatt J, Young F, Looney RJ. B lymphocyte depletion in the treatment of systemic lupus (SLE): phase I/II trial of rituximab (Rituxan $囚$ ) in SLE Arthritis Rheum 2002; 46: 289.

14. Eisenberg R. SLE - Rituximab in lupus. Arthritis Res Ther. 2003; 5(4): 157-159.

15. Navarra SV, Guzmán RM, Gallacher et al., BLISS-52 Study Group. (2011 Feb 26). „Efficacy and safety of belimumab in patients with active systemic lupus erythematosus: a randomised, placebo-controlled, phase 3 trial,.. Lancet. 377 (9767): 721-31.

16. Furie R, Petri M, Zamani O, et al., BLISS-76 Study Group. (2011 Dec). „A phase III, randomized, placebo-controlled study of belimumab, a monoclonal antibody that inhibits B lymphocyte stimulator, in patients with systemic lupus erythematosus,.. Arthritis Rheum. 63 (12): 3918-30.

17. Popovic M, i sar. U: Terapija reumatičnih oboljenja. Sistemski eritemski lupus Vojnoizdavački Zavod. Beograd 1999; 382-91. 
18. Uramoto KM, Michet CJ Jr, Thumboo J, Sunku J, O`Fallon WM, Gabriel SE. Trends in the incidence and mortality of systemic lupus erythematosus, 1950-1992. Arthritis Rheum. Jan 1999;42(1):46-50.

19. Gladman DD, Urowitz MB. Systemic lupus erythematosus. In: Klippel JH,Dieppe PA.Rheumatology, Mosby,London, 1998; 7,11-118.

20. Danchenko N, Satia JA, Anthony MS. Epidemiology of systemic lupus erythematosus: a comparison of worldwide disease burden. Lupus. 2006;15(5):308-18.

21. Gladman DD, Urowitz MB. Prognosis, mortality and morbidity in systemic lupus erythematosus. In: Wallace DJ, Hahn BH. Dubois' lupus erythematosus. 7th ed. Philadelphia: Lippincott Williams \& Wilkins; 2007:1333-53.

22. Manzi S, Meilahn EN, Rairie JE, Conte CG, Medsger TA Jr, Jansen-McWilliams L, et al. Agespecific incidence rates of myocardial infarction and angina in women with systemic lupus erythematosus: comparison with the Framingham Study. Am J Epidemiol. Mar 1 1997;145(5):408-15.

23. Murali R, Jeyaseelan L, Rajaratnam S, John L, Ganesh A. Systemic lupus erythematosus in Indian patients: prognosis, survival and life expectancy. Natl Med J India. Jul-Aug 1997;10(4):159-64.

24. Wang F, Wang CL, Tan CT, Manivasagar M. Systemic lupus erythematosus in Malaysia: a study of 539 patients and comparison of prevalence and disease expression in different racial and gender groups. Lupus. 1997;6(3):248-53.

25. Rahman A, Isenberg DA. Systemic lupus erythematosus. N Engl J Med 2008; 358(9): 929-39.

26. D‘Cruz DP,Khamashta MA, Hughes GR. Systemic lupus erythematosus. Lancet. 2007;369(9561):587-96.

27. Mok CC, Lau CS. Pathogenesis of systemic lupus erythematosus. J Clin Pathol. 2003; 56 (7): 481-90.

28. Pisetsky DS. Systemic lupus erythematosus. A. Epidemiology, pathology and pathogenesis. In: Klippel JH, ed. Primer on the rheumatic diseases, 11th ed. Georgia, USA: Arthritis Foundation, 1997:246-51.

29. Schur PH. Genetics of systemic lupus erythematosus. Lupus 1995;4:425-37.

30. Klein J, Sato A. The HLA system. Second of two parts. N Engl J Med 2000; 343 (11): 782-6.

31. Atkinson JP. Complement activation and complement receptors in systemic lupus erythematosus. Springer Semin Immunopathol 1986;9:179-94.

32. Sullivan KE. Genetics of systemic lupus erythematosus. Clinical implications. Rheum Dis Clin North Am 2000;26:229-56.

33. Mok CC, Lau CS. Profile of sex hormones in male patients with systemic lupus erythematosus. Lupus 2000;9:252-7.

34. Petri M. Exogenous estrogen in systemic lupus erythematosus: oral contraceptives and hormone replacement therapy. Lupus 2001;10:222-6. 
35. Reidenberg MM, Drayer DE, Lorenzo B, et al. Acetylation phenotypes and environmental chemical exposure of people with idiopathic systemic lupus erythematosus. Arthritis Rheum 1993;36:971-3.

36. Cooper GS, Dooley MA, Treadwell EL, et al. Smoking and use of hair treatments in relation to risk of developing systemic lupus erythematosus. J Rheumatol 2001;28:2653-6.

37. Casciola-Rosen L, Rosen A. Ultraviolet light-induced keratinocyte apoptosis: a potential mechanism for the induction of skin lesions and autoantibody production in LE. Lupus 1997;6:175-80.

38. Herrmann M, Hagenhofer M, Kalden JR. Retroviruses and systemic lupus erythematosus. Immunol Rev 1996;152:145-56.

39. Pathak S, Mohan C. Cellular and molecular pathogenesis of systemic lupus erythematosus: lessons from animal models. Arthritis Res Ther. 2011;13(5):241.

40. Tan EM, Cohen AS, Fries JF, Masi AT, McShane DJ, Rothfield NF et al. The 1982 revised criteria for the classification of systemic lupus erythematosus. Arthritis Rheum. 1982; 25:1271-7.

41. Hochberg MC. Updating the American College of Rheumatology revised criteria for the classification of systemic lupus erythematosus. Arthritis Rheum. 1997;40:1725.

42. Cervera R, Khamashta MA, Font J, Sebastiani GD, Gil A, Lavilla P et al. Morbidity and mortality in systemic lupus erythematosus during a 10-year period. A comparison of early and late manifestations in a cohort of 1000 patients. Medicine (Baltimore) 2003;82(5):299-308.

43. Cervera R, Khamashta MA, Font J, Sebastiani GD, Gil A, Lavilla P et al. Systemic lupus erythematosus: clinical and immunologic patterns of disease expression in a cohort of 1,000 patients. The European Working Party on Systemic Lupus Erythematosus. Medicine (Baltimore) 1993;72:113-24.

44. Kovacević Z, Rabrenović V, Jovanović D, Petrović M, Rabrenović M, Matunović R. Gastrointestinal symptomatology as first manifestation of systemic erythematous lupus. Vojnosanitetski pregled.2009; 66(3):238-41.

45. Alarcon-Segovia D. The treatment of systemic lupus erythematosus. Clin Exp rheumatol 1994; 12 (11): 49-53.

46. Najafi CC, Korbert SM, Lewis EJ, Schwartz MM, Reichlin M, Evans J. Significance of histologic patterns of glomerular injury upon long term prognosis in severe lupus glomerulonephritis. Kidney Int 2001; 59:2156-63.

47. Kobert SM, Lewis EJ, Schwartz MM, Reichlin M, Evans J, Rohdes RD. Factors predictive of outcome in severe lupus nephritis. Am J Kidney Dis 2000; 35: 904.

48. Bagavant H, Fu SM. Pathogenesis of kidney disease in systemic lupus erythematosus. Curr Opin Rheumatol. 2009;21(5):489-94.

49. Huong DL, Papo T, Beaufils H, Wechsler B, Blétry O, Baumelou A et al. Renal involvement in systemic lupus erythematosus. A study of 180 patients from a single center. Medicine (Baltimore) 1999;78(3):148-66.

50. Korbet SM, Schwartz MM, Evans J, Lewis EJ and for the Collaborative Study Group. Severe Lupus Nephritis: Racial Differences in Presentation and Outcome. JASN 2007; 18 (1): 244-54. 
51. Gladman DD, Ibañez D, Urowltz MB. Systemic lupus erythematosus disease activity index 2000. The Jour of Rheumatol. 2002; 29 (2):288-91.

52. Hsieh YP, Wen YK, Chen ML. The value of early renal biopsy in systemic lupus erythematosus patients presenting with renal involvement. Clin Nephrol 2012;77(1):18-24.

53. Christopher-Stine L, Siedner M, Lin J, Haas M, Parekh H, Petri M, Fine DM. Renal biopsy in lupus patients with low levels of proteinuria. J Rheumatol 2007;34(2):332-5.

54. Bihl GR, Petri M, Fine DM. Kidney biopsy in lupus nephritis: look before you leap. Nephrol Dial Transplant 2006; 21: 1749-52.

55. Weening JJ, D Agati VD, Schwartz MM et al. The classification of glomerulonephritis in systemic lupus erythematosus revisited . Kidney Int 2004;65:521-30.

56. Churg J, Bernstein J, Glassock RJ. Lupus nephritis. En: Classification and Atlas of Glomerular Disease, 2nd ed. New York, Igaku-Shoin, 1995, p51.

57. Weening JJ, D’Agati VD, Schwartz MM, Seshan SV, Alpers CE, Appel GB et al. The classification of glomerulonephritis in systemic lupus erithematous revisited. J Am Soc Nephrol 2004; 15:241-250.

58. Dalton K, Smith M, Thurman JM. The development of membranous lupus nephritis during treatment with mycophenolate mofetil for proliferative renal disease. Nephrol Dial Transplant Plus 2010; 3(4): 346-348.

59. Austin HA 3rd, Muenz LR, Joyce KM, Antonovych TT, Balow JE: Diffuse proliferative lupus nephritis: Identification of specific pathologic features affecting renal outcome. Kidney Int 1984; 25: 689-695.

60. Kidney Disease: Improving Global Outcomes (KDIGO) Glomerulonephritis Work Group KDIGO Clinical Practice Guideline for Glomerulonephritis. Chapter 12: Lupus nephritis. Kidney Intern Suppl. 2012; 2: 221-232.cal Practice Guideline forerulonephritisKDIGO

61. Rahman A, Isenberg DA. Systemic Lupus Erythematosus. N Engl J Med 2008; 358: 929-39.

62. Contreras G, Pardo V, Leclercq B, Lenz O, Tozman E, O'Nan P et al. Sequential Therapies for Proliferative Lupus Nephritis. N Engl J Med 2004; 350 (10): 971-80.

63. Chen TK, Estrella MM, Fine DM. Predictors of kidney biopsy complication among patients with systemic lupus erythematosus. Lupus 2012; 21 (8): 848-54.

64. Flower DR. The lipocalin family: structure and function. Biochem J 1996; 318: 1-14.

65. Gutman S, Kessler LG. The US Food and Drug Administration perspective on cancer biomarker development. Nat Rev Cancer.2006;6:565-571.

66. Pisitkun T, Johnstone R, Knepper MA. Discovery of Urinary biomarkers. Molecular Cellular Proteomics 2006; 5 (10): 1760-71.

67. Lameire N, Van Biesen W, Vanholder R. Acute kidney injury. Lancet 2008; 372 (9653):1863-5.

68. Djukanović Lj.Ispitivanje bolesnika sa oboljenjem bubrega . U: Bolesti bubrega.Urednici Djukanović Lj, Oštrić V. Zavod za udzbenike i nastavna sredstva, Beograd 1999; 3-31.

69. American Society of Nephrology Renal Research Report. J Am Soc Nephrol 2005; 16(7): 1886-903. 
70. Portilla D, Dent C, Sugaya T, et al.Liver fatty acid-binding protein as a biomarker of acute kidney injury after cardiac surgery. Kidney Int 2008; 73:465-72.

71. Devarajan P. Emerging biomarkers of acute kidney injury. Contrib Nephrol 2007; 156: 203-12.

72. Xue JL, Daniels F, Star RA, . Kimmel PL, Eggers PW, Molitoris BA et al. Incidence and mortality of acute renal failure in medicare beneficiaries, 1992 to 2001. J Am Soc Nephrol 2006;17:1135-2.

73. Miranda KC, Bond DT, McKee M, Skog J, Păunescu TG, Da Silva N et al Nucleic acids within urinary exosomes/microvesicles are potential biomarkers for renal disease. Kidney Int. 2010; 78(2):191-9.

74. Moon PG, You S, Lee JE, Hwang D, Baek MC. Urinary exosomes and proteomics. Mass Spectrom Rev. 2011; 30(6):1185-202.

75. Hoorn EJ, Pisitkun T, Zietse R, Gross P, Frokiaer J, Wang NS et al . Prospects for urinary proteomics: exosomes as a source of urinary biomarkers. Nephrology (Carlton) 2005; 10(3):283-90.

76. Weissinger EM, Wittke S, Kaiser T, Haller H, Bartel S, Krebs R et al.Proteomic patterns established with capillary electrophoresis and mass spectrometry for diagnostic purposes. Kidney Int 2004; 65: 2426- 34.

77. Haubitz M, Wittke S, Weissinger EM, Walden M, Rupprecht HD, Floege J et al. Urine protein patterns can serve as diagnostic tools in patients with IgA nephropathy. Kidney Int 2005;67: 2313-20.

78. Mischak H, Schanstra JP. CE-MS in biomarker discovery, validation, and clinical application. Proteomics Clin Appl 2011; 5(1-2):9-23.

79. Mischak H, Delles C, Klein J, Schanstra JP. Urinary proteomics based on capillary electrophoresis-coupled mass spectrometry in kidney disease: discovery and validation of biomarkers, and clinical application. Adv Chronic Kidney Dis 2010; 17(6):493-506.

80. Triebel S, Blaser J, Reinke H, Tschesche HA. $25 \mathrm{kDa}$ a2-microglobulin-related protein is a component of the $125 \mathrm{kDa}$ form of human gelatinase. FEBS Lett 1992; 314: 386-8.

81. Kjeldsen L, Bainton DF, Sengelov H and Borregaard N. Identification of Neutrophil Gelatinase- Associated Lipocalin as a Novel Matrix Protein of Specific Granules in Human Neutrophils Blood 1994; 83 (3): 799-807.

82. Falke P, Elneihoum AM and Ohlsson K. Leukocyte Activation: Relation to Cardiovascular Mortality after Cerebrovascular Ischemia. Cerebrovasc Dis 2000; 10 (2): 97-101.

83. Kjeldsen L, Johnsen AH, Sengelov H, Borregaard N. Isolation and primary structure of NGAL, a novel protein associated with human neutrophil gelatinase. J Biol Chem 1993; 268: $10425-32$.

84. Kjeldsen L, Koch C, Arnljots K and Borregaard N. Characterization of two ELISAs for NGAL, a newly described lipocalin in human neutrophils. Immunol. Methods 1996; 198 (2): 155-164.

85. Uttenthal LO. NGAL: a marker molecule for the distressed kidney? Clin Lab Internat November 2005; 29(7): 39-41. 
86. Goetz DH, Holmes MA, Borregaard N, Bluhm ME, Raymond KN, Strong RK. The neutrophil lipocalin NGAL is a bacteriostatic agent that interferes with siderophore-mediated iron acquisition. Mol Cell 2002; 10: 1033-43.

87. Goetz DH, Willie ST, Armen RS, Bratt T, Borregaard N, Strong RK . Ligand preference inferred from the structure of neutrophil gelatinase associated lipocalin. Biochem J 2000; 39: 1935-41.

88. Raymond KN, Dertz EA, Kim SS (2003) Enterobactin: an archetype for microbial iron transport. Proc Natl Acad Sci USA 2003; 100: 3584-8.

89. Flo TH, Smith KD, Sato S, Rodriguez DJ, Holmes MA, Strong RK et al. Lipocalin 2 mediates an innate immune response to bacterial infection by sequestering iron. Nature 2004; 432: 917-21.

90. Jonsson P, Stahl ML, Ohlsson K. Extracorporeal circulation causes release of neutrophil gelatinase-associated lipocalin (NGAL). Mediators of Inflamm 1999; 8: 169-171.

91. Parikh CR, Edelstein CL, Devarajan P, Cantley L.Biomarkers of acute kidney injury: early diagnosis, pathogenesis, and recovery. J Investig Med 2007; 55: 333-40.

92. Mishra J, Dent C, Tarabishi R, Mitsnefes MM, Ma Q Kelly C et al . Neutrophil gelatinaseassociated lipocalin (NGAL) as a biomarker for acute renal injury after cardiac surgery. Lancet 2005; 365: 1231-8.

93. Wagener G, Jan M, Kim M, Mori K, Barasch JM, Sladen RN et al. Association between increases in urinary neutrophil gelatinase-associated lipocalin and acute renal dysfunction after adult cardiac surgery. Anesthesiology 2006; 105: 485-91.

94. Devarajan P. Neutrophil gelatinase-associated lipocalin-an emerging troponin for kidney injury. Nephrol. Dial. Transplant. (2008) 23 (12): 3737-3743.

95. Dent C, Ma Q, Dastrala S, Bennett M, Mitsnefes M. Plasma neutrophil gelatinase-associated lipocalin predicts acute kidney injury, morbidity and mortality after pediatric cardiac surgery: a prospective uncontrolled cohort study. Critical Care 2007; 11: R127.

96. Nguyen M, Devarajan P.Biomarkers for the early detection of acute kidney injury. Pediatr Nephrol 2008; 23:2151-7.

97. Shemin D, Dworkin LD. Neutrophil gelatinase-associated lipocalin (NGAL) as a biomarker for early acute kidney injury.Crit Care Clin. 2011;27(2):379-89.

98. 98. Parikh CR, Coca SG, Thiessen-Philbrook H, Shlipak MG, Koyner JL, Wang Z et al. Postoperative biomarkers predict acute kidney injury and poor outcomes after adult cardiac surgery. J Am Soc Nephrol. 2011; 22(9):1748-57.

99. Ralib AM, Pickering JW, Shaw GM, Devarajan P, Edelstein CL, Bonventre JV et al. Test Characteristics of Urinary Biomarkers Depend on Quantitation Method in Acute Kidney Injury . J Am Soc Nephrol 2012; 23: 322-33.

100. Elneihoum AM, Falke P, Axelsson L, Lundberg E, Lindgarde F and Ohlsson K.Leukocyte Activation Detected by Increased Plasma Levels of Inflammatory Mediators in Patients with Ischemic Cerebrovascular Diseases. Stroke 1996; 27: 1734- 8.

101. Cruz DN, Gaiao S, Maisel A, Ronco C, Devarajan P. Neutrophil gelatinase-associated lipocalin as a biomarker of cardiovascular disease: a systematic review. Clinical Chemistry and Laboratory Medicine 2012; 50 (9): 1533-45. 
102. Xu S, Venge P. Lipocalins as biochemical markers of disease. Biochim Biophys Acta 2000; 1482: 298-307.

103. Yilmaz A, Sevketoglu E, Gedikbasi A, Karyagar S, Kiyak A, Mulazimoglu M et al. Early prediction of urinary tract infection with urinary neutrophil gelatinase associated lipocalin. Pediatr Nephrol 2009; 24(12):2387-92.

104. Hatipoglu S, Sevketoglu E, Gedikbasi A, Yilmaz A, Kiyak A, Mulazimoglu M. Urinary MMP-9/NGAL complex in children with acute cystitis. Pediatr Nephrol. 2011; 26(8):1263-8.

105. Nielsen BS, Borregaard N, Bundgaard JR, Timshel S, Sehested M, Kjeldsen L. Induction of NGAL synthesis in epithelial cells of human colorectal neoplasia and inflammatory bowel diseases. Gut 1996; 38:414-420.

106. Oikonomou KA, Kapsoritakis AN, Theodoridou C, Karangelis D, Germenis A, Stefanidis I et al. Neutrophil gelatinase-associated lipocalin (NGAL) in inflammatory bowel disease: association with pathophysiology of inflammation, established markers, and disease activity. J Gastroenterol. 2012;47(5):519-30.

107. Boulikas T. Molecular mechanisms of cisplatin and its liposomally encapsulated form, Lipoplatin $^{\mathrm{TM}}$. Lipoplatin ${ }^{\mathrm{TM}}$ as a chemotherapy and antiangiogenesis drug. Cancer Ther 2007; 5: 349-76.

108. Santoso JT, Lucci JA, Coleman RL, Schafer I, Hannigan EV. Saline, mannitol, and furosemide hydration in acute cisplatin nephrotoxicity: a randomized trial. Cancer Chemother Pharmacol 2003; 52: 13-18.

109. Hanigan MH, Devarajan P. Cisplatin nephrotoxicity: molecular mechanisms. Cancer Therapy 2003; 1: 1-15.

110. Mishra J, Mori K, Ma Q, Kelly C, Barasch J, Devarajan P. Neutrophil Gelatinase-Associated Lipocalin: A novel early urinary biomarker for cisplatin nephrotoxicity. Am J Nephrol 2004; 24: 307-15.

111. Devarajan P. Update on mechanisms of ischemic acute kidney injury. J Am Soc Nephrol 2006; 17: 1503-20.

112. Devarajan P. Neutrophil gelatinase-associated lipocalin: new paths for an old shuttle. Cancer Therapy 2007; 5: 463-70.

113. Parikh CR, Jani A, Mishra J, Ma Q Kelly C, Barasch J. Urine NGAL and IL-18 are predictive biomarkers for delayed graft function following kidney transplantation. Am J Transplant 2006; 6: 1639-45.

114. Hollmen ME, Kyllönen LE,Inkinen KA, Lalla MLT, Merenmies J,Salmela KT. Deceased donor neutrophil gelatinase-associated lipocalin and delayed graft function after kidney transplantation: a prospective study. Critical Care 2011; 15: R121.

115. Magnusson NE,Hornum M, Jorgensen KA, Hansen JM, Bistrup C, Feldt-Rasmussen et al. Plasma neutrophil gelatinase associated lipocalin (NGAL) is associated with kidney function in uraemic patients before and after kidney transplantation. BMC Nephrology 2012;13:8.

116. Giaginis C,Zira A, Katsargyris A, Klonaris C,Theocharis S. Clinical implication of plasma neutrophil gelatinase -associated lipocalin (NGAL) concentrations in patients with advanced carotid atherosclerosis. Clin. Chem Lab Med 2010; 48(7):1035-41. 
117. Malyszko J, Malyszko JS, Bachorzewska-Gajewska H, Poniatowski B, Dobrzycki S, Mysliwiec M. Neutrophil gelatinase-associated lipocalin is a new and sensitive marker of kidney function in chronic kidney disease patients and renal allograft recipients. Transplantation Proceedings 2009; 41: 158-61.

118. Bolignano D, Lacquaniti A, Coppolino G, Campo S, Arena, Buemi M. Neutrophil gelatinase-associated lipocalin reflects the severity of renal impairment in subjects affected by chronic kidney disease. Kidney Blood Press Research 2008; 31(4):255-8.

119. Bolignano D, Donato V, Coppolino G, Campo S, Buemi A, Lacquaniti A et al.Neutrophil gelatinase-associated lipocalin (NGAL) as a marker of kidney damage. Am J Kidney Dis 2008; 52(3):595-605.

120. Bolignano D, Coppolino G, Campo S, Aloisi C, Nicocia G, Fristina N et al. Urinary neutrophil gelatinase-associated lipocalin (NGAL) is associated with severity of renal disease in proteinuric patients Nephrol. Dial. Transplant 2008; 23 (1): 414-416.

121. Bolignano D, Coppolino G, Lacquaniti A, Nicocia G, Buemi M. Pathological and prognostic value of urinary neutrophil gelatinase associated lipocalin in macroproteinuric patients with worsening renal function.Kidney Blood Press Res 2008; 31:274-9.

122. Wasilewska A, Zoch-Zwierz W, Taranta-Janusz K, Michaluk-Skutnik J. Neutrophil gelatinase-associated lipocalin (NGAL): a new marker of cyclosporine nephrotoxicity? Pediatr Nephrol. 2010; 25(5):889-97.

123. Qing X, Zavadil J, Crosby MB, Hogarth MP, Hahn BH, Mohan C et al .Nephritogenic antiDNA antibodies regulate gene expression in MRL/lpr mouse glomerular mesangial cells. Arth Rheum 2006; 54(7):2198-2210.

124. Hinze CH, Suzuki M, Klein-Gitelman M, Passo MH, Olson J, Singer NG et al. Neutrophil gelatinase-associated lipocalin is a predictor of the course of global and renal childhood-onset systemic lupus erythematosus disease activity. Arthritis Rheum 2009;60(9):2772-81.

125. Rubinstein T, Pitashny M, Putterman C. The novel role of neutrophil gelatinase-B associated lipocalin (NGAL)/Lipocalin-2 as a biomarker for lupus nephritis. Autoimmun Rev 2008;7(3):229-34.

126. Sidiropoulos PI, Kritikos HD, Boumpas DT. Lupus nephritis flares. Lupus 2005;14(1): 49-52.

127. Fiehn C. Early diagnosis and treatment in lupus nephritis: how we can influence the risk for terminal renal failure. The Journal of Rheumatology. 2006;33(8):1464-1466.

128. Mok CC.Therapeutic options for resistant Lupus nephritis. SemArth Rheum 2006; 36(2):71-81.

129. Brunner HI, Mueller M, Rutherford C, Passo MH, Witte D, Grom A, et al.l.Urinary neutrophil gelatinase-associated lipocalin as a biomarker of nephritis in childhood-onset systemic lupus erythematosus.Arthritis Rheum 2006; 54 (8): 2577-84.

130. Suzuki M, Wiers KM, Klein-Gitelman MS, Haines KA, Olson J, Onel KB, et al.Neutrophil gelatinase-associated lipocalin as a biomarker of disease activity in pediatric lupus nephritis. Pediatric Nephrology2008; 23(3): 403-12. 
131. Bennett M, Dent CL, Ma Q Dastrala S, Grenier F, Workman R, et al. Urine NGAL predicts severity of acute kidney injury after cardiac surgery: a prospective study. Clin J Am Soc Nephrol 2008;3: 665 - 73.

132. Mitsnefes MM, Kathman TS, Mishra J, Kartal J, Khoury PR, Nickolas TL, et al. Serum neutrophil gelatinase-associated lipocalin as a marker of renal function in children with chronic kidney disease. Pediatr Nephrol 2007; 22(1):101-8.

133. Koura HM, Galal A, Manal F. Elshamaa FM, Kandil MD, Elghorori AE, et al. Urinary neutrophil gelatinase -associated lipokalin as a marker of disease activity in patients with lupus nephritis . Int J Acad Reasrch 2011; 3 (1): 141-146.

134. Yang CC, Hsieh SC, Li KJ, Wu CH, Lu MC, Tsai CY et al. Urinary Neutrophil GelatinaseAssociated Lipocalin Is a Potential Biomarker for Renal Damage in Patients with Systemic Lupus Erythematosus . J Biomed Biotechnol 2012; 2012: 759313.

135. Pitashny M, Schwartz N, Qing X, et al.Urinary lipocalin- 2 is associated with renal disease activity in human lupus nephritis. Arthritis Rheum 2007;56 (6):1894- 1903.

136. Allison JS. Lupus nephritis: Urinary NGAL predicts renal flares in lupus nephritis. Nature Reviews Nephrology 2010; 6(5):250.

137. Nassabeh N. Connective tissue diseases: Edging closer to the early detection of renal flare in adult SLE.Nat Rev Rheumatol 2010; 6(5): 181.

138. Rubinstein T, Pitashny M, Levine B, Schwartz N, Schwartzman J, Weinstein E, et al. Urinary neutrophil gelatinase-associated lipocalin as a novel biomarker for disease activity in lupus nephritis. Rheumatology 2010;49:960-971. 
ПРИЛОЗИ 


\section{УНИВЕРЗИТЕТ У КРАГУЈЕВЦУ \\ ФАКУЛТЕТ МЕДИЦИНСКИХ НАУКА}

\section{КЉУЧНА ДОКУМЕНТАЦИЈСКА ИНФОРМАТИКА}

Редни број - РБ

Идентификациони број - ИБР:

Тип документације - ТД:

Монографска публикација

Тип записа - Т3:

Текстуални штампани материјал

Врста рада - ВР:

Докторска дисертација

Аутор- АУ:

Прим др Виолета Рабреновић

Ментор/коментор - MH:

Проф др Зоран Ковачевић

Наслов рада - НР:

Дијагностички значај одређивања нивоа липокалина удруженог са неутрофилном гелатиназом у урину код болесника са лупус нефритисом

Језик публикације - ЈП:

Српски / ћирилица

Језик извода - ЈИ:

Српски/Енглески

Земља публиковања - ЗП:

Србија

Уже географско подручје УГП:

Београд

Година - Го:

2013

Издавач - ИЗ:

Ауторски репринт

Место и адреса - MC:

Паунова 89 Београд

Физичи опис рада - ФО:

Научна област - НО:

Медицина

Научна дисциплина- ДИ:

Интерна Медицина

Предметна одредница/

кључне речи- ПО:

лупус нефритис, уринарни биомаркер, липокалин удружен са неутрофилном гелатиназом.

УДК

Чува се - ЧУ:

Библиотека Факултета Медицинских Наука, Универзитета у Крагијевцу 


\section{Важна напомена MH:}

Извод ИД: У проспективној клиничкој студији на 40 болесника са лупус нефритисом, испитиван је значај одређивања уринарног биомаркера: Липокалина удруженог са неутрофилном гелатиназом (НГАЛ). Циљ студије било је праћење и поређење односа параметара активности лупус нефритиса, између испитиване и контролне групе (по 20 болесника) на почетку лечења и 2 и 4 месеца по започињању лечења. Статистички значајне корелације добијене су између уринарног НГАЛ-а и анти дс-ДНА антитела,, 24ч. протеинурије, односа уринарних протеина и креатинина (Упр/кре), СЛЕДАИ/р скора. Поређењем са другим параметрима активности лупус нефритиса, запажено је да је у/НГАЛ статистички најсигнификантнији показатељ. Резултати су указали на значај у дијагностиковању активности болести, односно потврди ремисије лупус нефритиса, чиме се може применити адекватнији терапијски модалитет и индивидуални приступ лечењу. Ова студија указује да би одређивање уринарног НГАЛ код болесника са лупус нефритисом у свакодневном клиничком раду допринело најоптималнијем учинку лечења.

Датум прихватања теме од стране ННВ - ДП:

18. 01.2012

Датум одбране - До:

Чланови комисије- КО:

1. Проф. др Стево Пљеша, председник

Медицински факултет

Универзитета у Београду

2. Проф. др Душан Стефановић, члан

Медицински Факултет

Војномедицинска-Академија

Универзитет Одбране, Београд

3. Доц. др Дејан Петровић, члан

Факултет медицинских-наука,

Универзитет у Крагујевцу 
Accession number ANO:

Identification number INO:

Documentation type DT:

Monographic publication

Type of record TR:

Textual material printed

Contents code CC:

Ph. D Thesis

Author AU:

Prim dr Violeta Rabrenovic

Menthor/co-mentor MN

Ph D Zoran Kovacevic

Title TT:

Diagnostic significance determining the level of urinary neutrophil gelatinasa associated lipocalin in patients with lupus nephritis

Language of text LT:

Serbian /Cyrillic

Language of abstract LA:

Serbian /English

Country of publication $\mathrm{CP}$ :

Serbia

Locality of publication LP:

Belgrade

Publication year PY:

2013

Publisher PU:

Publication place PP:

Велgrade, Paunova 89

Physical description PD:

Scientific field SF:

Medicine

Scientific discipline SD:

Internal medicine

Subject/key words SKW:

Lupus nephritis, urinary biomarkers, Activity desease, neutrophil gelatinase associated lipocalin

UDC

Holding data HD:

Library of Faculty of Medical Science, University of Kragujevac, Serbia 


\section{Note N:}

Abstract AB: In a prospective clinical study of 40 patients with lupus nephritis, we examined significance of determining urinary biomarker Neutrophil gelatinase-associated lipocalin (uNGAL). The aim of the study was to monitor and compare the parameters of activity of lupus nephritis, between the examined and control groups of 20 patients each, at baseline, and 2 and 4 months after the start of treatment. Statistically significant correlations were obtained between urinary NGAL, and anti-ds DNA antibodies, 24h. proteinuria, urinary protein to creatinine ratio (Upr/cr), and SLEDAI / r score. Comparing with other parameters of activity of lupus nephritis, it was noticed that UNGAL is the most statistically significant parameter. The results show the importance in the diagnosis of disease activity, and in confirmation of remission of lupus nephritis, which can result in application of more appropriate therapeutic modality and individual approach to treatment. This study suggests that the determination of UNGAL in patients with lupus nephritis in daily clinical practice can contribute to the optimal effect of treatment.

\section{Accepted by the Scientic Board on ASB: 18.01 .2012}

\section{Thesis defense committee members} (Degree/name/surname/title/faculty) DB:

PhD Stevo Plješa, Chairman

Medical Faculty Belgrade

PhD Dušan Stefanović, Member

Military Medical Academy, Belgrade

Doc dr Dejan Petrović, Member

Faculty of Medical Science, Kragujevac 


\title{
Биографија Аутора
}

\author{
Име и презиме: Виолета Рабреновић \\ Датум и место рођења: $\quad$ 10.09.1963 Словењградец, Словенија \\ Радно место: \\ Клиника за нефрологију Војномедицинска \\ Академија, Београд; Асистент Медицински \\ Факултет- Војномедицинска Академија \\ Телефон: \\ $+381113608010$ \\ Електронска пошта: \\ violettarab@gmail.com \\ Основне студије: \\ 1988 Медицински факултет \\ Универзитет Београд \\ Докторска дисетрација: \\ Дијагностички значај одређивања нивоа \\ липокалина удруженог са неутрофилном \\ гелатиназом у урину код болесника са лупус \\ нефритисом \\ Ментор: $\quad$ Проф др Зоран Ковачевић
}

Познавање страних језика: Енглески 


\section{Author - Curriculum Vitae}

Name:

Date and place of birth:

Position:

Phone:

E mail:

MD:

Ph D Thesis:

Mentor:

Language proficiency
Violeta Rabrenović

10.09.1963 Slovenjgradec, Slovenija

Internist - nephrologist,

Military Medical Academy, Belgrade

$+381113608010$

violettarab@gmail.com

1988 Medical Faculty, University of Belgrade

Diagnostic significance determining the level of urinary neutrophil gelatinasa associated lipocalin in patients with lupus nephritis

$\mathrm{Ph}$ D Zoran Kovacevic

Englsh 


\section{Списак објављених радова - List of Publications}

1. Rabrenović V, Kovačević Z, Jovanović D, Rabrenović M, Dimitrijević J, Škatarić V, Popović D, Abugras S. Mikroskopski poliangitis.Vojnosanit Pregl 2000; 58(3): 323-28.

2. RabrenovićV, Nunić N, Kovačević Z, Rabrenović M, Jovanović D, Škatarić V. Bubrežna insuficijencija u multiplom mijelomu-učestalost, terapija i uticaj na preživljavanje.U Predavanja i sažeci VII jugoslovenski kongres za nefrologiju, dijalizu i transplantaciju.2002 16-19 oktobar; Niš 2002:63.

3. Rabrenović V, Kovačević Z, Rabrenović M, Jovanović D, Stanković-Popović V, Škatarić V. Učestalost i kliničke karakteristike nefrotskog sindroma u pojedinim tipovima primarnih glomerulonefritisa. U predavanja i sažeci VII jugoslovenski kongres za nefrologiju, dijalizu i transplantaciju; 2002 16-19 oktobar; Niš 2002:68.

4. Rabrenović V, Kovačević Z, Rabrenović M, Jovanović D, Škatarić V, Stanković-Popović V. Mikroskopski poliangitis - kliničko laboratorijske karakteristike i terapijski pristup. U predavanja i sažeci VII jugoslovenski kongres za nefrologiju,dijalizu i transplantaciju; 2002 16-19 oktobar; Niš 2002:87

5. Rabrenović V, Nunić N, Škatarić V, Kovačević Z. Akutna bubrežna insuficijencija u multiplom mijelomu. U knjiga sažetaka VI kongres nefrologa Jugoslavije 1998; 20-22 septembar; Beograd 1998:14.

6. Rabrenović V, Kovačević Z, Rabrenović M, Skataric V, Hrvacevic R, Jovanovic D. Treatment of membranoproliferative glomerulonephritis presenting with nephrotic syndrome. In book of abstracts World Congres of Nephrology 2003; 8-12june; Berlin 2003:618.

7. Rabrenović V. Mikofenolat mofetil - novi lek za primarne glomeruloneritise. U mikofenolat mofetil (MMF) savremena imunosupresija: Ispitujući sadašnjost, otkrivamo budućnost- apstrakti. 2003; maj; Beograd 2003:14-5.

8. Rabrenović V, Kovačević Z, Rabrenović M, Škatarić V, Jovanović D, Ignjatović LJ. Treatment of resistant nephrotic syndrome in primary glomerulonephritis by mycophenolate mofetil. In book of abstracts XLI congress of the European renal association European Dialysis and Transplant association 2004; 15-18 May; Lisabon 2004:40

9. Rabrenović V, Kovačević Z, Rabrenović M, Škatarić V, Jovanović D, Popović Stanković V. Microscopic polyangiitis: clinical and laboratory characteristic and therapeutical approach. In Bantao Journal Vol 1 (issue 1) 2003; Sept; Varna 2003:85.

10. Rabrenović V, Nunić $\mathrm{N}$, Mijušković $\mathrm{Z}$, Trajković $\mathrm{Z}$, Ristić L,Tankosić D.Osobenosti IgA mijeloma analiza 47 bolesnika lečenih od 1980-95 godine. $U$ abstrakti-radova $X$ jugoslovenski hematološki dani sa međunarodnim učešćem; 1996 10-12 oktobar; Niš. Niška Banja 1996:112.

11. Rabrenović V, Kovačević Z, Rabrenović M, Jovanović D. Treatment of membranous nephropathy presenting with nephrotic syndrome - our experience.In Bantao Journal Vol 3 ( 1): p 37 ; 2005; Sept8-11; Ohrid 2005

12. Rabrenović V, Kovačević Z, Rabrenović M, Jovanović D, Ignjatović Lj. Asimptomatske abnormalnosti urina. Zbornik sažetaka: VIII kongras interne medicine Srbije i Crne Gore. 20-24 jun 2006; Igalo 2006:134 
13. Rabrenović V. Lečenje anemije kod bolesnika na hroničnoj peritoneumskoj dijalizi. U Maksić Dj, Editor. Peritoneumska dijaliza Beograd:Calibris ; 2006. p. 695-708

14. Rabrenović V, Ignjatović Lj, Kovačević Z, Paunić Z, Vavić N, Maksić Dj. Transplantacija bubrega kod bolesnika na peritoneumskoj dijalizi - desetogodišnje iskustvo (1996-2006). Abstract book: I Congres of Serbia and Montenegro Society of nephrology 28-30 September 2006; Novi Sad 2006:185

15. Rabrenović V, Kovačević, Rabrenović M, Jovanović D. Secundary polycithemia in patients with focal segmental glomerulonephritis (FSGN). Abstract book: XVIII Danube symposium of nephrology 26-28 September 2006 ; Novi Sad 2006:62 PW 11

16. Rabrenović V, Kovačević Z, Jovanović D, Rabrenović M, Milović N, CerovićS. Plazmocitom sa ekstramedularnom lokalizacijom u mokraćnoj bešici - neobična lokalizacija. Vojnosanit Pregl 2006; 63 (11):975-8.

17. Rabrenović $\mathrm{V}$, Kovačević $\mathrm{Z}$, Jovanović $\mathrm{D}$, Rabrenović $\mathrm{M}$. Abdominal pain as first manifestation of the systemic lupus erythematosus. Book of abstracts World Congres of Nephrology 21-25 april 2007; Rio de Janeiro, Brasil 2007:360 MPO 1123

18. Rabrenović V, Ignjatović Lj, Kovačević Z, Jovanovic D, Vavić N. Complication in patients with transplanted kidney who were previously treated peritoneal dialysis ten year experiance. Book of abstracts: 8th Congress BANTAO 16-19 september 2007; Belgrade, Serbia 2007: Tx- 0-04

19. Rabrenović V, Kovačević Z, Ignjatović Lj, Jovanovic D, Maksić Đ, Vavić N, Paunić Z. Desetogodišnje iskustvo u transplantaciji bubrega kod bolesnika na peritoneumskoj dijalizi (1996-2006). Medicinski pregled 2007; LX (Suppl 2):151-4.

20. Rabrenović V, Kovačević Z, Jovanović D, Škatarić V. Lečenje hemoragične groznice sa bubrežnim sindromom. Urednik. Zoran Kovačević, Dragan Jovanović, Ana Gligić, Veselin Škatarić; Red Apple doo, Aleksandrovac 2008; 97-101.

21. Rabrenović V, Kovačević Z, Jovanović D, Škatarić V. Dijagnoza i diferencijalna dijagnoza hemoragične groznice sa bubrežnim sindromom.Urednik. Zoran Kovačević, Dragan Jovanović, Ana Gligić, Veselin Škatarić; Red Apple doo, Aleksandrovac 2008; 92-7.

22. Rabrenović V, Kovačević Z, Jovanovic D, Ignjatović Lj. Complications in the kidney transplanted patients previously treated by peritoneal dialysis - 10-year experience in a Single center. Bantao Jornal 2007; 5 (2): 94-6.

23. Rabrenović V, Kovačević Z, Jovanović D, Rabrenović M, Vavić N. Unusual presentation of plasmocytoma in urinary bladder. Book of abstracts: 13 th Congress of Balcan Military Medical Committee 1-5 june 2008; Kusadasi, Turkiye. PP 086

24. Rabrenović V, Poskurica M, Kovačević Z, Nešić V, Savin M, Mitić B, Dimković N, Čučković Č, Vujić D, Plješa S, Peruničić-Peković G, ČuriS, Mitić I, Ratković M, Merinković J, Jovanović D. Treatment of lupus Nephritis by Mucophenolate Mofetil. Kidney Blood Press Res 2010; 33:297-303.

25. Rabrenović V, Kovačević Z Jovanović D, Petrović M, Obrenčević K, Čukić Z, Gašić B. Hemoragična groznica sa bubrežnim sindromom ( HGBS) - naša iskustva (19892009). Knjiga sažetaka 1 Kongres nefrologa Srbije 7-10 oktobar 2010 Beograd, Srbija s. 21. 
26. Rabrenović V, Ćulafić $S$, Rabrenović $M$, Kovačević Z Matunović R, Petrović $M$, Gašić B. Aneurizma arterije subklavije kod bolesnice sa hroničnom bubrežnom insuficijencijom kao uzrok glavobolje - prikaz slučaja. Knjiga sažetaka 1 Kongres nefrologa Srbije 7-10 oktobar 2010; Beograd, Srbija PP 35 .s 63

27. Kovačević Z, Jovanović $D$, Rabrenović V, Maksić $Đ$, Paunić Z. Povoljni i neželjeni efekti ACE inhibitora u lečenju dijabetesne nefropatije. U Stefanović $V$, urednik. Dijabetesna nefropatija. Niš; Izdavačka delatnost Univerziteta u Nišu, 2002: 183- 8.

28. Jovanović D, Kovačević Z, Rabrenović V. Ciklosporin A u terapiji nefrotskog sindroma usled fokalno-segmenrne glomeruloskleroze.Vojnosanit Pregl 2000; 57(3):303-7.

29. Jovanović D, Kovačević Z, Rabrenović V, Škatarić V. Akutni poststreptokokni glomerulonefritis kod odraslih-terapija kortikosteroidima da ili ne? Vojnosanit Pregl 2001; 58(2):161-7.

30. Kovačević Z, Jovanović D, Milović N, Rabrenović V. Subkapsularni renalni hematomozbiljna komplikacija vantelesne litotripsije.Vojnosanit Pregl 2000;57(5):597-602.

31. Kovačević Z, Jovanović D, Škatarić V, Rabrenović V. Uticaj inhibitora angiotenzin konvertirajućeg enzima na progresiju bubrežne slabosti. Vojnosanit Pregl 2000; 57(5):577-84.

32. Kovačević Z, Škatarić V, Jovanović D, Pervulov S, Rabrenović V. Komplikacije perkutane translumenske renalne angioplastike (PTRA) - prikaz slučaja. Vojnosanit Pregl 1999; 56(4): 431-4.

33. Kovačević Z, Jovanović D, Škatarić V, Dimitrijević J, Rabrenović V, Nožić D i sar. Lečenje hroničnog virusnog hepatitisa B i sekundarnog membranoproliferativnog glomerulonefritisa rekombinantnim alfa-2 interferonom. Vojnosanit Pregl 2000; 57(2):235-40.

34. Jovanović D, Kovačević Z, Stanković Popović V, Rabrenović V i sar. Terapija lupusnog nefritisa standardnim protokolom lečenja ciklosporinom. Srpski Arhiv 2002; suppl (3):13-9.

35. Kovačević Z, Mitrović D, Tomić I, Jovanović D, Škatarić V, Dimitrijević J, Rabrenović V i sar. Pulsne doze ciklofosfamida u lečenju Wegenerove granulomatoze. Vojnosanit Pregl 1999; 56(1):31-7.

36. Kovačević Z, Jovanović D, Rabrenović V, Škatarić V, Pavlović G. Sekundarni glomerulonefritisi. U Predavanja i sažeci VII jugoslovenski kongres za nefrologiju, dijalizu i transplantaciju. 2002, 16-19 oktobar; Niš 2002:15-16.

37. Kovačević Z, Rabrenović V, Škatarić V, Jovanović D. Hemoperfuzija u lečenju trovanja. U Komplikacije dijalize - XI škola dijalize; 2003 28-30 maj; Leskovac 2003:56-8.

38. Škatarić V, Jovanović D, Kovačević Z, Rabrenović V, Dimitrijević J, Gligić A. Akutna bubrežna insuficijencija (ABI)kod hemoragijske groznice $s$ bubrežnim sindromom(HGBS)-terapija i ishod.U predavanja i sažeci VII jugoslovenski kongres za nefrologiju dijalizu i transplantaciju; 2002 16-19 oktobar; Niš 2002:61.

39. Rabrenović M, Matunović R, Rabrenović V, Petrović S, Stojanović M, Damjanović M. Significance of high blood pressure in patients with lupus glomerulonephritis In Abstract book of International simposium on hypertension; 2002 29september-2 october; Belgrade. 
40. Škatarić V. M, Kovačević Z, Jovanović D, Rabrenović V, Dimitrijević J, Gligić A. Akutni pulmonalni sindrom (APS) kod hemoragijske groznice $s$ bubrežnim sindromom (HGBS). U predavanja i sažeci VII jugoslovenski kongres za nefrologiju, dijalizu i transplantaciju;2002 16-19 oktobar;Niš 2002:81. BI01P.

41. Škatarić V. M, Kovačević Z, Jovanović D, Rabrenović V, Dimitrijević J, Božović B. Kliničke karakteristike hemoragične groznice s bubrežnim sindromom (HGBS) u našoj zemlji. U predavanja i sažeci VII jugoslovenski kongres za nefrologiju, dijalizu i transplantaciju; 2002 16-19 oktobar; Niš 2002:81BI02P.

42. Kovačević Z, Mitrović D, Jovanović D, Škatarić V, Maksić Đ, Rabrenović V. Akutna bubrežna insuficijencija u bolesnika sa Wegenerovom granulomatozom (WG).U knjiga sažetaka VI kongres nefrologa jugoslavije; 1998 20-22 septembar; Beograd 1998:13.

43. Kovačević Z, Jovanović D, Škatarić V, Maksić Đ, Rabrenović V. The effect of target hemoglobin(Hb) concentration on recombinant human erythropoetin(r-HuEPO) therapy adverse effects in hemodialisis patients. In book of abstractsThird Congress of the Balcan Cities Association of Nefrology, Dialysis, Transplantation and Arteficial Organs1998; 18-20 september; Belgrade, 1998:47.

44. Stanković Popović V, Jovanović D, Kovačević Z, Hrvačević, Rabrenović V, Dimitrijević J. Ciklosporin A u lečenju oblika lupus nefritisa rezistentnih na primenu standardnih terapijskih protokola. Knjiga sažetaka: VII Jugoslovenski kongres za nefrologiju, dijalizu i transplantaciju, 16-19 oktobra; Niš 2002: 82.

45. Stanković Popović V, Jovanović D, Kovačević Z, Hrvačević, Dimitrijević J.Rabrenović V. Treatment of cyclophosphamid resistant lupus nephritis using cyclosporine. Our experience. In Bantao Journal Vol 1, Issue 1 2003; Sept ; Varna 2003: 100.

46. Rabrenović M, Rabrenović V, Matunović R, Kovačević Z. The role of hypertension in patients with lupus nephritis. In Bantao Journal Sept 8-11;0hrid 2005; 3 ( 1): p 37.

47. Rabrenović M, Rabrenović V, Kovačević Z, Zgradić I, Matunović R. The significance of secundary antiphospholipid syndroma in systemic lupus erythematosus. Abstract book: XVIII Danube symposium of nephrology 26-28 September 2006; Novi Sad 2006:63 PW 12.

48. Jevtić M, Drašković M, Kovačević Z, Jovanović D, Rabrenović V, Marjanović I. Translumbar-intracaval central venous catheter (CVC) as an procedure to the chronic hemodialysis program in patients with exhausted vascular procedure (case report). Abstract book: XVIII Danube symposium of nephrology 26-28 September 2006; Novi Sad 2006:99. PW 42.

49. Ignjatović Lj, Vavić N, Paunić Z, Rabrenović V, Kovačević Z, Hrvačević R. Renal allograft function in the patients with double immunosuppressive protocol. Abstract book: XVIII Danube symposium of nephrology 26-28 September 2006; Novi Sad 2006: 144. PT 31.

50. Ignjatović Lj, Hrvačević R, Vavić N, Paunić Z, Rabrenović V, Drašković B, Kovačević Z. Proteinuria in kidney allograft recipients who are switched from calcineurine inhibitors to sirolimus due to slow increasment of ser. creatinin. XVIII Danube symposium of nephrology 26-28 September 2006; Novi Sad 2006: 145. PT 32 
51. Ignjatović Lj, Kovačević Z, Hrvačević R, Vavić N, Rabrenović V, Paunić Z, Simeunović R. Prva iskustva u transplantaciji bubrega od živog donora, preko pozitivne unakrsne reakcije. Abstract book: I Congres of Serbia and Montenegro Society of nephrology 28-30 September 2006; Novi Sad 2006:184.

52. Škatarić V, Popović M, Kovačević Z, Rabrenović V, Jovanović D, Gligić A. Akutni kororonarni sindrom (AKS) kod hemoragijske groznice sa bubrežnim sindromom (HGBS). Abstract book: I Congres of Serbia and Montenegro Society of nephrology 2830 September 2006; Novi Sad 2006:195. PP 1

53. Vavić N, Ignjatović Lj, Hrvačević R, Rabrenović V, Paunić Z, Kovačević Z. Klinički ishod lečenja akutnog vaskularnog odbacivanja (AVO) na odeljenju za transplantaciju VMA. Abstract book: I Congres of Serbia and Montenegro Society of nephrology 28-30 September 2006; Novi Sad 2006:247. PS 20

54. Ignjatović Lj, Balint B, Hrvačević R, Kovačević Z, Vavić N, Rabrenović V, Paunić Z, Simonović R. Prva iskustva u transplantaciji bubrega preko krvno grupne barijere (Donor: $B$ Rh $\mathbf{D}$ pozitivan, recipijent $=\mathbf{R h} \mathbf{D}$ pozitivan). Abstract book: I Congres of Serbia and Montenegro Society of nephrology 28-30 September 2006; Novi Sad 2006:249. PP21

55. Matunovic R, Rabrenovic V, Rabrenovic M, Kovacevic Z, Mijailovic Z, Jovanovic D. Kontrastna nefropatija kod bolesnika sa transplantiranim bubregom i akutnim koronarnim sindromom nakon koronarne angiografije. Zbornik radova: Treci simpozijum iz kardionefrologije sa medjunarodnim ucescem. 2007, Vrnjacka Banja 2007: 230.

56. Rabrenović. M, Rabrenović V, Zoranović U. Razvoj hiperbarične medicine Vojnosanit Pregl 2006; 63 (7): 667-71.

57. Kovacevic Z, Rabrenović V, Jovanovic D, Pilcevic D. Asymptomatic isolated hematuria in military population. Book of abstracts World Congres of Nephrology 21-25 april 2007; Rio de Janeiro, Brasil 2007, 361. MP0 1029

58. Jovanovic D, Kovacevic Z, Rabrenović V. Prognosis and evolution of post- streptococcal glomerulonephritis in military population. Book of abstracts World Congres of Nephrology 21-25 april 2007; Rio de Janeiro, Brasil 2007, 361. MPO 1028

59. Kovacevic Z, Jovanovic D, Rabrenović V, Vavic N. Freqency and characteristic of IgA glomerylonephritis in young military population with asymptomatic hematuria Book of abstracts: 8th Congress BANTAO 16-19 september 2007; Belgrade, Serbia 2007: CN P 36.

60. Rabrenović. M, Matunovic R Rabrenović V, Kovacevic Z. Lupus nephritis and cardiovascular disorders. Book of abstracts: 8th Congress BANTAO 16-19 september 2007; Belgrade, Serbia 2007: CN P 31

61. Rabrenović. M, Matunovic R, Rabrenović V, Jovanovic D, Kovacevic Z. Lupus nephritis and cardiovascular disorders - Our clinical expirience. Bantao Jornal 2007; 5(2): 65-9.

62. Kovacevic Z, Jovanovic D, Rabrenović V, Dimirtijević J, Djukanovic LJ. Asymptomatic microscopic haematuria in young males. Int J Clin Pract 2007; 1-7.

63. Rabrenović. M, Matunovic R Rabrenović V, Zoranović U. Hiperbaricna medicina mogucnosti i dileme . Vojnosanit Pregl 2008; 65(3): 235-8. 
64. Tabrenović. M, Matunovic R Rabrenović V, Todorović V, Mićević D, Zoranović U. Hiperbarična medicina i urgentna stanja. Vojnosanit Pregl 2008; 65(8): 645-7.

65. Kovacevic Z, Obrencevic K, Jovanovic D, Savic D, Rabrenovic V, Skatarić V. Clinical manifestations and serologic analysis of hemorrhagic fever with renal syndrome in Serbia and teritory of former Yugoslavia. Book of abstracts: 13 th Congress of Balcan Military Medical Committee 1-5 june 2008; Kusadasi, Turkiye. PP 237.

66. Savin M, Nesić V, Marinkovic J, Pljesa S, Perunicic-Pekovic G, Dimkovic N, Vujic D, Cuckovic C, Kovacevic Z, Rabrenovic V, Jovanovic D. 1-Year prospective study of Cell Cept efects in treatment of glomerulonephritis. Book of abstracts: 8th Congress BANTAO 16-19 september 2007; Belgrade, Serbia 2007: CN P 36.

67. Savin M, Nesić V, Marinkovic J, Pljesa S, Perunicic-Pekovic G, Dimkovic N, Vujic D, Cuckovic C, Kovacevic Z, Rabrenovic V, Jovanovic D. Cell Cept efects on dynamics in changing of primary glomerylar disease v.s. lupus nephritis 1 year treatment study. Book of abstracts: 8th Congress BANTAO 16-19 september 2007; Belgrade, Serbia 2007: CN P 36.

68. Ignjatović Lj, Jovanovic D, Kovačević Z, Vavić N, Rabrenović V, Obrencevic K. Ten years experience in attempt to increase number of kidney transplants from alive donor - Single center study Neph Dial Transp 2007; vol. 22: 402.

69. Kovačević Z, Jovanović D, Rabrenović V, Vavić N, Petrović M. Značaj biopsije bubrega u asimptomatskim abnormalnostima urina. IX kongres internista Srbije, Zlatibor, hotel Čigota, jun 07-11, 2008. abs p 198.

70. Kovačević Z, Savić D, Jovanović D, Rabrenović V, Vavić N i Čukić Z: Metaboličko ispitivanje kalkuloze urotrakta-retrospektivna petogodišnja studija. . IX kongres internista Srbije, Zlatibor, hotel Čigota, jun 07-11, 2008. abs p 212.

71. Jovanović D, Kovačević Z, Rabrenović V, Tadić J, Božinović Z: Savremeni terapijski pristup u lečenju bolesnika sa SLE i lupus nefritisom. IX kongres internista Srbije, Zlatibor, hotel Čigota, jun 07-11, 2008. abs U 35.

72. Kovačević Z, Patrović M, Jovanović D, Rabrenović V, Vavić N: Imunoadsorbcija-nova metoda u lečenju imunoloških bolesti. IX kongres internista Srbije, Zlatibor, hotel Čigota, jun 07-11, 2008. abs U 37.

73. Jovanović D, Obrenčević K, Kovačević Z, Tadić J, Rabrenović V, Božinović Z: Moguće kasne renalne sekvele hemoragijske groznice sa bubrežnim sindromom. IX kongres internista Srbije, Zlatibor, hotel Čigota, jun 07-11, 2008. abs U 191.

74. Jovanović D, Kovačević Z, Rabrenović V, Tadić J, Božinović Z: Nove mogućnosti u terapiji uznapredovalih karcinoma bubrega (RCC). IX kongres internista Srbije, Zlatibor, hotel Čigota, jun 07-11, 2008. abs U 192.

75. Kovačević Z, Rabrenović V, Jovanović D, Petrović M, Rabrenović M, Matunović R. Gastrointestinalna simptomatologija kao prva manifestacija sistemskog eritemskog lupusa . Vojnosanit Pregled 2009; 66 (3): 238-41.

76. Dimković N, Jovanović D, Kovačević Z, Rabrenović V, Nešić V, Savin M, Mitić B, Ratković M, Čurić S, Mitić I, Plješa S, Peruničić Peković G, Marinković J, Popović J, Vujić D. Mycophenolate mofetil (MMF) in high risk patients with primary glomerulonephritis: results of one - year prospective study. Nephron Clinical Practice 2009; 111:c189c196. 
77. Dimitrijevic J, Kovacevic Z, Jovanovic D, Ignjatovic Lj, Rabrenovic V, Djukanovic Lj. Asymptomatic urinary abnormalities: Histopathological analysis. Pathology Research and Practice 2009; 205: 295-302.

78. Kovačević Z, Jovanović D, Rabrenović V. Patofiziologija hemoragične groznice sa bubrežnim sindromom. Urednik. Zoran Kovačević, Dragan Jovanović, Ana Gligić, Veselin Škatarić; Red Apple doo, Aleksandrovac 2008; 49-60.

79. Jovanović D, Kovačević Z, Škatarić V, Rabrenović V. Klinička slika hemoragične groznice sa bubrežnim sindromom. Urednik. Zoran Kovačević, Dragan Jovanović, Ana Gligić, Veselin Škatarić; Red Apple doo, Aleksandrovac 2008; 60-74.

80. Matunović R, Mijailović Z, Rabrenović M, Rabrenović V. Novi biohumoralni markeri za diferencijalnu dijagnozu dispneje kod bolesnika sa sumnjom na srčanu bolest. Medicinski Pregled 2010; 5-6: 387-92 .

81. Čukić Z, Vavić N, Kovačević Z, Rabrenović V, Mijušković M. Akutna intermitentna porfirija - dijagnostički problem u nefrološkoj praksi, sa prikazom slučaja. Knjiga sažetaka 1 Kongres nefrologa Srbije 7-10 oktobar 2010 Beograd, Srbija PP17, s 56.

82. Kovačević Z, Jovanović D, Rabrenović V, Radojević M, Ignjatović Lj, Balint B. Originalna metoda za uklanjanje antitela u transplantaciji bubrega preko krvno grupne barijere- naša iskustva. Knjiga sažetaka 1 Kongres nefrologa Srbije 7-10 oktobar 2010 Beograd, Srbija S 26.

83. Jovanović D, Ignjatović Lj, Jovanović A, Kovačević Z, Rabrenović V. Savremeni principi lečenja lupus nefritisa. Knjiga sažetaka 1 Kongres nefrologa Srbije 7-10 oktobar 2010 Beograd, Srbija S 16.

84. Vavić N, Kovačević Z, Radojević M, Ignjatović Lj, Rabrenović V, Paunić Z. Tumori posle transplantacije bubrega, naša iskustva. Knjiga sažetaka 1 Kongres nefrologa Srbije 7-10 oktobar 2010 Beograd, Srbija S 28. 


\section{ИЗЈАВА О АУТОРСТВУ}

Потписани-а: Прим др Виолета Рабреновић

Број уписа: $\quad$ 2006/99

И 3 J А В Љ У J Е М

да је докторска дисертација под насловом: Дијагностички значај одређивања нивоа липокалина удруженог са неутрофилном гелатиназом у урину код болесника са лупус нефритисом

- резултат сопственог истраживачког рада

- да предложена дисертација у целини, ни у деловима није била предложена за добијање било које дипломе према студијским програмима других високошколских установа,

- да су резултати коректно наведени и

- да нисам кршио/ла ауторска права и користио интелектуалну својину других лица

У Крагујевцу

Потпис аутора

Прим др Виолета Рабреновић

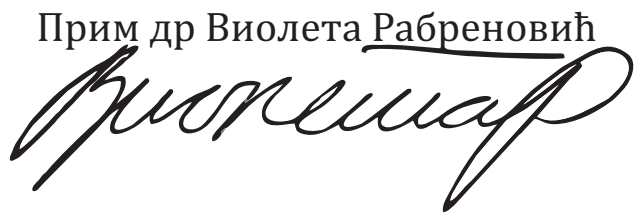




\section{ИЗЈАВА О ИСТОВЕТНОСТИ ШТАМПАНЕ И ЕЛЕКТРОНСКЕ ВЕРЗИЈЕ ДОКТОРСКОГ РАДА}

Име и презиме аутора: рим др Виолета Рабреновић

Број уписа: 2 2006/99

Студијски програм: Докторске академске студије

Наслов рада: ијагностички значај одеђивања нивоа липокалина удруженог са неутрофилном гелатиназом у урину код болесника са лупус нефритисом

Ментор:

Потписани: Вримета Рабреновић

Изјављујем да је штампама верзија мог докторског рада истоветна електронској верзији коју сам предао/ла за објављивање на порталу Дигиталног репозиторијума Универзитета у Крагујевцу.

Дозвољавам да се објаве моји лични подаци везани за добијање академског звања доктора наука као што су име и презиме, година и место рођења и датум одбране рада.

Ови лични подаци могу се објавити на мрежним станицама дигиталне библиотеке, у електронском каталогу и у публикацијама Универзитета у Крагујевцу.

У Крагујевцу

Потпис аутора

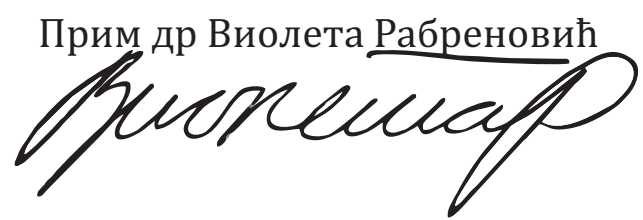




\section{ИЗЈАВА О КОРИШКЕЊУ}

Овлашћујем Универзитетску библиотеку да у Дигитални репозиторијум Универзитета у Крагујевцу унесе моју докторску дисертацију под насловом:

\section{Дијагностички значај одређивања нивоа липокалина удруженог са неутрофилном гелатиназом у урину код болесника са лупус нефритисом}

која је моје ауторско дело.

Моју докторску дисертацију похрањену у Дигитални репозиторијум Универзитета у Крагујевцу, могу да користе сви који поштују одредбе садржане у одабраном типу лиценце Креативне заједнице (Creative commons) за коју сам се одлучио/ла:

1. Ауторство

2. Ауторство-некомерцијално

(3.)Ауторство-некомерцијално- без прераде

4. Ауторство-некомерцијално- делити под истим условима

5. Ауторство-без прераде

6. Ауторство- делити под истим условима

(Молимо да заокружите само једну од 6 понуђених лиценци, чији је кратак опис дат на образцу број 4.)

У Крагујевцу

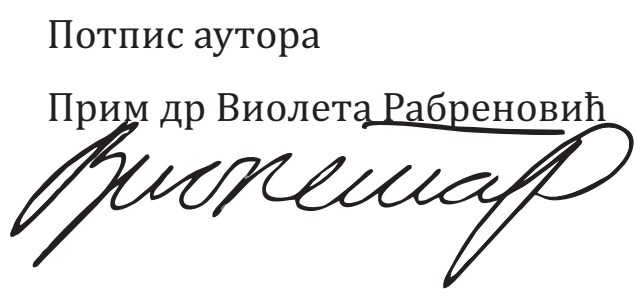

